\title{
GEOLOGIA E PETRO-METALOGÊNESE DA MINERALIZAÇÃO DE OURO DA MINA SÃO BENTO, QUADRILÁTERO FERRÍFERO - MG
}

\author{
Fernando Benegas Valladares
}

Orientador: Prof. Dr. Johann Hans Daniel Schorscher

$$
\text { DISSERTAÇÃO DE MESTRADO }
$$

Programa de Pós-Graduação em Mineralogia e Petrologia 


\section{Resumo}

A mineralização aurífera da mina São Bento, localizada na porção NE do Quadrilátero Ferrífero, Minas Gerais, foi estudada com métodos de campo e laboratoriais mineralógicospetrográficos e geoquímicos, visando contribuir a petro-metalogênese desse depósito em ambiente greenstone belt arqueano.

A mineralização ocorre no Grupo Nova Lima vulcano-sedimentar máfico estratigraficamente médio do greenstone belt arqueano Rio das Velhas (Supergrupo Rio das Velhas) em formações ferríferas bandadas (BIF) de tipo Algoma de fácies óxido com magnetita, carbonato, silicato, sulfeto e mistas.

Levantamentos de campo e subsolo confirmam a atitude geral N30-35E/50-55SE do Grupo Nova Lima e sua subdivisão de mapeamento, na área do manifesto, em quatro unidades litoestratigráficas informais, de NW para SE designadas: Formação Ferrífera Inferior, Formação Grafitosa Basal, Formação Ferrífera São Bento e Formação Carrapato.

A Formação Ferrífera São Bento, hospedeira da mineralização de ouro foi subdividida informalmente em Membro Ferrífero Basal, com até quatro horizontes mineralizados (Oeste, Middle, São Bento e Leste) e intercalações de BIF estéreis e xistos metapelíticos finos; e Membro Ferrífero do Topo, de BIF de fácies carbonato, óxido com magnetita e silicato.

Todos os horizontes mineralizados são BIF de fácies sulfeto puras ou mistas, em proporções subordinadas variáveis, com fácies carbonato, óxido e silicato, apresentando correlação direta entre os teores de ouro e de sulfetos totais.

Ouro e também todos os sulfetos, pirita, arsenopirita e pirrotita (principais) e esfalerita e calcopirita (subordinados) ocorrem em diversas gerações texturais e genéticas.

Metamorfismo regional principal e tectônica causaram recristalização e deformação heterogênea nos sulfetos, como a concentração por segregação de cristais deformados de pirrotita, alongados e estirados na foliação. Diferentemente, pirita e arsenopirita ocorrem como cristais idioblásticos com bordas idiomórficas (sem inclusões) e partes internas ricas em inclusões de minerais de ganga, outros sulfetos e ouro, além de cristais idiomórficos (sem inclusões) neoformados; eventualmente, sofreram ainda processos rúpteis de fraturamento/quebra.

O ouro ocorre principalmente como inclusões refratárias $(\leq 5 \mu \mathrm{m}-\leq 10 \mu \mathrm{m})$ na pirita e arsenopirita (perfazendo $\sim 80 \%$ do metal do minério lavrado) e como grãos mais grossos ( $Z$ $20 \mu \mathrm{m}-250 \mu \mathrm{m}$ ) livres ou intercrescidos nos concentrados de pirrotitas deformadas, sugerindo crescimento acretivo dos grãos durante a remobilização com redistribuição e recristalização principalmente da pirrotita, mas também dos demais sulfetos com inclusões primárias de ouro.

Entre as diferentes fácies de BIF não existem diferenças geoquímicas significativas para os óxidos maiores e os metais de transição $\mathrm{V}, \mathrm{Cr}, \mathrm{Co}, \mathrm{Ni}$, e $\mathrm{Zn}$, os quais ainda demonstram similaridades à BIF de Isua.

Os teores de ETR para os BIF de fácies carbonato, óxido e sulfeto são similares, apresentando teores totais baixos e fracionamento dos ETR leves, assim como pronunciadas anomalias negativas de Ce e positivas de $\mathrm{Eu}$.

A mineralização aurífera de São Bento é estratiforme e de origem sedimentar vulcanoexalativa distal (singenética), por suas características geológicas, petro-metalogenéticas e geoquímicas. Processos tectono-metamórficos e hidrotermais posteriores geraram principalmente efeitos mineralógico-texturais e estruturais. 


\begin{abstract}
The gold mineralization of the São Bento Mine in the NE of the Quadrilatero Ferrifero, Minas Gerais, was studied with field and mineralogical, petrographical and geochemical laboratory methods, aiming at a contribution to the petrogenesis and metallogenesis of this deposit in an Archean greenstone belt environment. The mineralization occurs in the volcano-sedimentary mafic Nova Lima Group, the middle unit of the Rio das Velhas greenstone belt stratigraphical succession (Rio das Velhas Supergroup ), in Algoma-type banded iron formations (BIF) of oxyde-magnetite-, carbonate-, silicate-, sulphide- and mixed facies.

Field and underground studies confirmed N30-35E/50-55SE as the major structural outline of the Nova Lima Group and its subdivision in the mining-area into four informal lithostratigraphical NE-trending mapping units from NW to SE, named: Lower Banded Iron Formation (Formação Ferrifera Inferior), Basal Graphitic Formation (Formação Grafitosa Basal), São Bento Iron Formation (Formação Ferrifera São Bento) and Carrapato Formation (Formação Carrapato).

The São Bento Iron Formation hosts the gold mineralization and was informally subdivided into the Basal Ferriferous Member (Membro Ferrifero Basal) containing up to four mineralized horizons (West, Middle, São Bento, and East) with intercalations of barren BIF and metapelitic schists, and the Ferriferous Member of the Top (Membro Ferrifero do Topo) of carbonate-, oxyde-magnetite-, and silicate-facies BIF. The mineralized horizons are sulphide-facies BIF, pure or mixed, in variable but subordinated proportions, with carbonate-, oxyde- and silicate-facies BIF. They show direct correlation between the gold contents and total sulphides.

Gold and also all of the sulphides, pyrite, arsenopyrite and pyrrhotite (majors) and sphalerite and calcopyrite (minors) occur in various textural and genetic generations. The main regional metamorphism and tectonics caused recrystallization and heterogeneous deformation of the sulphides, for instance, the concentration through segregation of deformed pyrrhotite crystals into lenticular aggregates parallel to the foliation. Differently, pyrite and arsenopyrite occur as idioblastic crystals showing idiomorphic clean border zones (without inclusions) and internal parts rich in inclusions of gangue minerals, other sulphides and gold; they also occur as newly-formed clean idiomorphic crystals (without inclusions) and, both types, still underwent later ruptile deformations of fracturing/ breakage.

Gold occurs mainly as refractory inclusions $(\leq 5 \mu \mathrm{m}-\leq 10 \mu \mathrm{m})$ in the pyrite and arsenopyrite (totalling $\sim 80 \%$ of the metal content of the mined ore) and as coarser grains ( $\geq 20 \mu \mathrm{m}-$ $250 \mu \mathrm{m})$ free in the ore and intergrown in the lenticular concentrations of deformed pyrrhotites. The coarser gold grains suggest accretive growth during the metamorphic remobilization with redistribution, deformation and recrystallization mainly of the pyrrhotite, but also of other sulphides that contained refractory gold inclusions.

The different BIF facies ot the São Bento Iron Formation do not show significant geochemical differences for the major oxides and the transition metals $\mathrm{V}, \mathrm{Cr}, \mathrm{Co}, \mathrm{Ni}$ and $\mathrm{Zn}$, which, however, do show similiarities to the Isua-BIF. The REE contents of the carbonate-, oxydeand sulphide-facies are similar, too, showing low total-REE, fractionation of the light REE and clear negative anomalies of $\mathrm{Ce}$ and positive anomalies of Eu.

In view of its geological, petro-metallogenetic and geochemical characteristics the gold mineralization of the São Bento mine is stratiform and considered of sedimentary volcanoexhalative distal (syngenetic) origin. Later tectono-metamorphic and hydrothermal processes caused mainly mineralogical-textural and structural modifications.
\end{abstract}


"Aos meus pais, sempre" 


\section{Agradecimentos}

Agradeço à São Bento Mineração S/A, pelo apoio dado a este trabalho, na pessoa de Sérgio Luís Martins Pereira, diretor do Departamento de Geologia.

Ao meu orientador e amigo Johann Hans Daniel Schorscher, pelos ensinamentos, ajuda e incentivo em todos os momentos.

Aos amigos que fiz dentro da São Bento Mineração em Santa Bárbara, em especial a Juliano Efigênio Ferreira, excelente geólogo e grande amigo; Tarcísio Estevão de Lima; Paulinho; Luís, Angela e a todo o pessoal com quem tenho a honra de trabalhar a 1.300 metros de profundidade (Agnaldo, Jozé Zeferino, Jozé Hugo, Ronaldo e Tião).

Para Palloma Lopes Costa Melo e família pelo apoio e carinho.

A todos os amigos, presentes ou não, do meio geológico ou não, que tive a sorte de conhecer e que pretendo levar para sempre. 


\section{Resumo}

\section{Abstract}

Índice

Índice de Figuras

Índice de Fotos

Índice de Fotomicrografias

Indice de Anexos

Índice de Tabelas

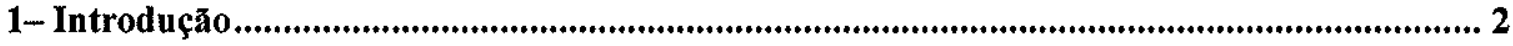

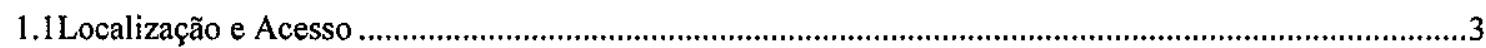

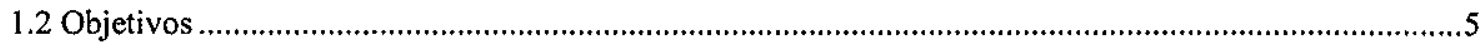

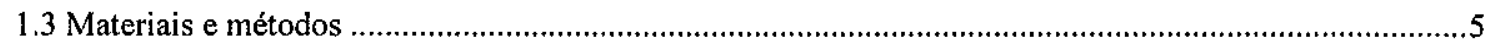

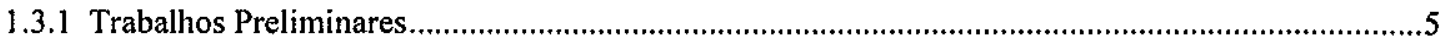

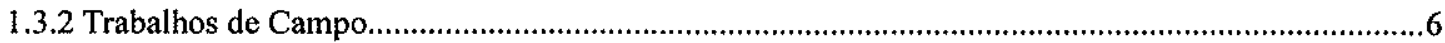

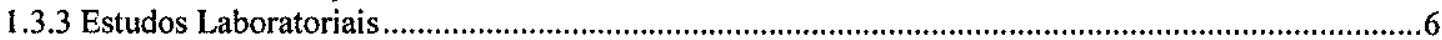

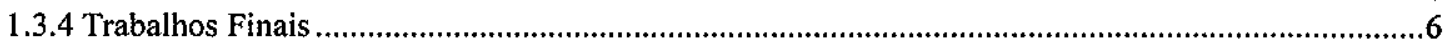

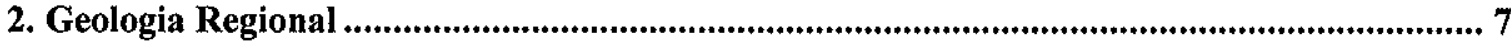

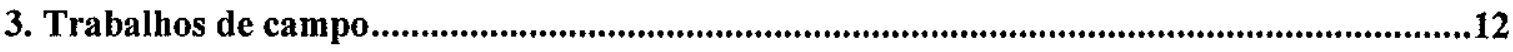

3.1 Litoestratigrafia

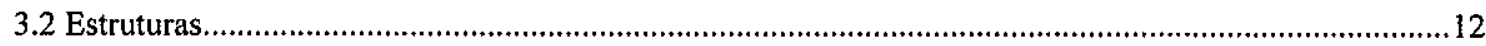

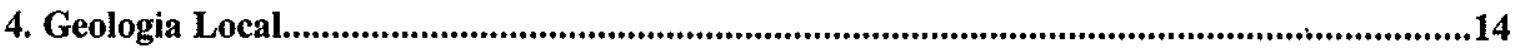

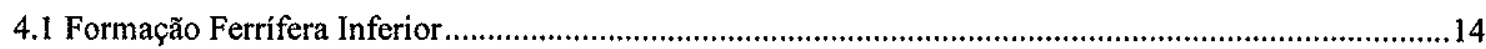

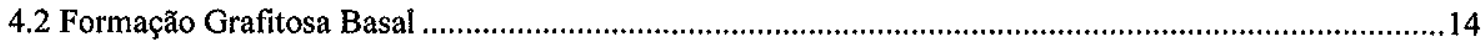

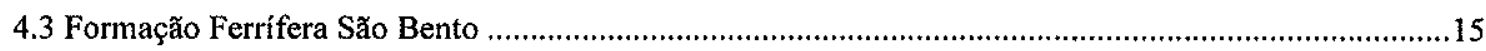

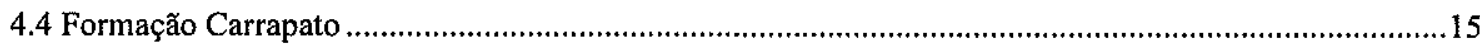

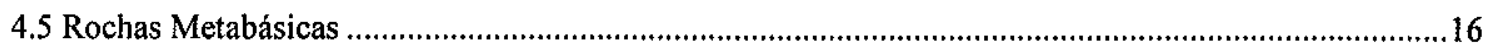

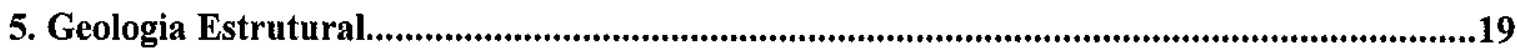

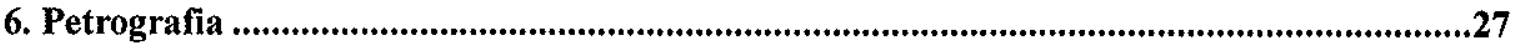

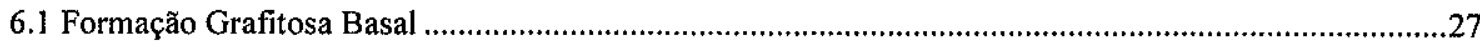

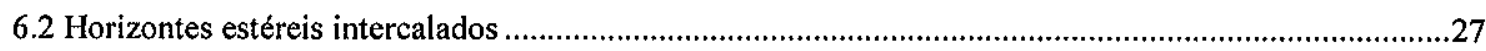

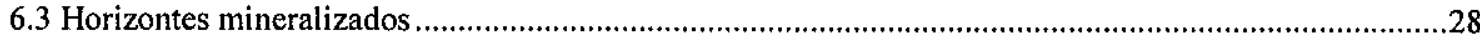

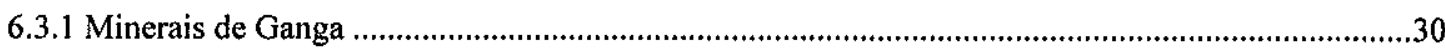

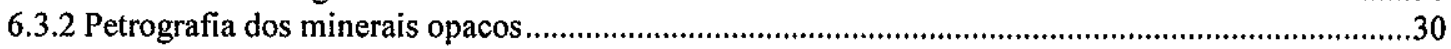

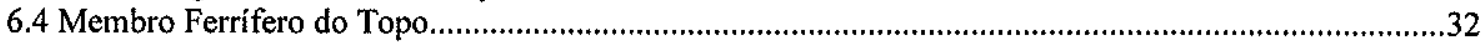

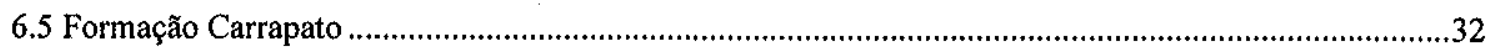

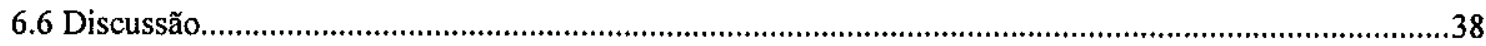

7. Análises geoquímicas multielementares ..................................................................................39

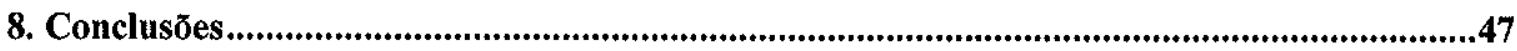

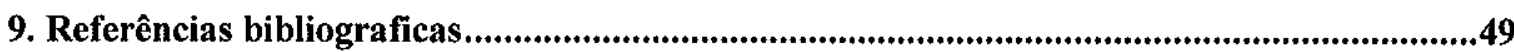




\section{Índice de Figuras}

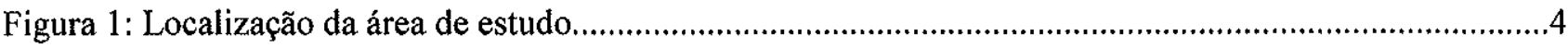

Figura 2: Localização e contesto geológico da região da mina São Bento.....................................................11

Figura 3: Mapa geológico do manifesto da mina São Bento.................................................................17

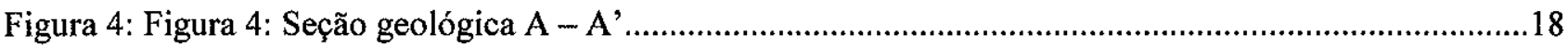

Figura 5: Composições médias dos elementos maiores da formação ferrífera São Bento................................40

Figura 6: Composições médias dos elementos maiores de BIF fácies silicato de São Bento...........................41

Figura 7: Composições médias dos elementos maiores de BIF fácies carbonato de São Bento.......................41

Figura 8: Composições médias dos elementos maiores de BIF fácies óxido de São Bento..............................42

Figura 9: Composiç̃̃es médias dos elementos maiores de BIF fácies sulfeto de São Bento...........................42

Figura 10: Comparação dos teores médios de alguns metais de transição de BIF de Isua (Dymek \& Klein, 1988) e São Bento.

Figura 11: Comparação dos teores médios de alguns metais de transição nos BIF e nas rochas encaixantes de

São Bento. .43

Figura 12: Correlação Au x S em BIF de fácies sulfeto de São Bento 44

Figura 13: Correlação Au x As em BIF de fácies sulfeto de São Bento .44

Figura 14: Padrões de teores médios dos elementos terras raras de BIF e rochas encaixantes de São Bento (normalização NASC) 


\section{Índice de Fotos}

Foto 1: Dobra isoclinal assimétrica em formação ferrífera bandada fácies óxido. Nível $24,1^{\circ}$ interdrive sul (Foto: Juliano E. Ferreira).

Foto 2: Falha de orientação aproximada norte-sul truncando oblíquamente a zona mineralizada. Nível 25, $3^{\circ}$ interdrive sul

Foto 3: Veios de quartzo boudinados paralelos ao bandamento dos BIF de fácies sulfeto.Na porção inferior e superior da foto observa-se o bandamento do BIF de fácies óxido/silicato. Nível $25,1^{\circ}$ interdrive norte. Largura da foto $2,5 \mathrm{~m}$

Foto 4: Veios de quartzo sulfetados dispostos em sistema echelon truncando oblíquamente a forrmação ferrífera composta por bandas regulares quartzo-carbonáticas e de magnetita.. Largura da da foto 2,5 metros. Nivel 25 Reef Drive sul.

Foto 5: Amostra de formação ferrífera apresentando bandamento composto por carbonato e magnetita, truncado por veios quartzo-sulfetados dispostos em echelon. 


\section{Índice de Fotomicrografias}

Fotomicrografia la: Amostra SB-02, lâmina delgada SB-02, largura da foto $2,8 \mathrm{~mm}$, luz transmitida, polarizadores cruzados. Bandamento milimétrico entre bandas quartzo-carbonáticas e bandas compostas por clorita e sericita onde concentram-se opacos estirados paralelamente ao bandamento. Níveis quartzo carbonáticos boudinados.

Fotomicrografia 1b: Amostrra SB-05, lâmina delgada SB-05-2, largura da foto $2,8 \mathrm{~mm}$, luz transmitida, polarizadores cruzados. Bandamento quartzo-carbonático com presença de opacos intersticiais e como cristais subedrais a euedrais.

Fotomicrografia lc: Amostra SB-09, lâmina delgada SB-09-2, largura da foto 2,8 mm., luz transmitida, polarizadores cruzados. Aspecto geral do bandamento quartzo-carbonático com opacos apresentando granulometria variável.

Fotomicrografia 1d: Amostra SB-09, lâmina delgada SB-09-1, largura da foto 2,8 mm., luz transmitida, polarizadores cruzados. Veio clorítico em contato brusco com o bandamento quartzo-carbonático...... .29

Fotomicrografia 2a: Amostra L-64, lâminda delgada L-64, largura da foto $2,8 \mathrm{~mm}$., luz transmitida, polarizadores cruzados. Veio composto por estilpnomelano e clorita, apresentando-se paralelo ao bandamento

Fotomicrografia 2b: Amostrta SB-09, seção polida SB-09-2, largura da foto $0,7 \mathrm{~mm}$., luz refletida, polarizadores paralelos. Ouro incluso em pirrotita.

Fotomicrografia 2c: Amostra SB-15a, seção polida SB-15a-1, largura da foto 1,4 mm., luz refletida, polarizadores paralelos. Ouro incluso em pirrotita, em contato com arsenopirita. .34

Fotomicrografia 2d: Amostra SB-09, seção polida SB-09-1, largura da foto 2,8 mm., luz refletida, polarizadores paralelos. Pirrotita xenomórfica estirada paralela à foliação. 34

Fotomicrografia 3a: Amostra SB-09, lâminda delgada polida SB-09-1, largura da foto 0,7 mm., luz refletida, polarizadores paralelos. Seção rômbica de arsenopirita em contato com idioblasto de pirita. Pirita subedral com inclusões de magnetita e esfalerita, cinza médio a escuro respectivamente no centro esquerdo da foto.

Fotomicrografia 3b: Amostra SB-09, seção polida SB-09-1, largura da foto 1,4 mm., luz refletida, polarizadores paralelos. Intercrescimento de pirrotita (mais escura) e arsenopirita. Cristais de magnetita tabular ocorrem estirados como inclusões na arsenopirita.

Fotomicrografia 3 c: Amostra SB-15, seção polida SB-15C-2, largura da foto 1,4 mm., luz refletida, polarizadores paralelos. Ouro livre em contato com arsenopirita idioblástica sem inclusões

Fotomicrografia 3d: Amostra SB-09, seção polida SB-09-1, largura da foto 1,4 mm., luz refletida, polarizadores paralelos. Inclusões de pirrotita e arsenopirita em pirita idioblástica. 36

Fotomicrografia 4a: Amostra SB-10, seção polida SB-10-1, largura da foto 0,7 mm., luz refletida, polarizadores paralelos. Inclusões de ouro em pirita rica em inclusões (ganga e pirrotita).

Fotomicrografia 4b: Amostra SB-10, seção polida SB-10-2, largura da foto $2,8 \mathrm{~mm}$., luz refletida polarizadores paralelos. Diminutas inclusões de ouro e pirrotita em pirita idioblástica. 
Índice de Anexos

\section{Anexo 1:}

- Mapa Geológico (1:200) e de localização de amostras do Nível 15 - Travessa 2070, Mina São Bento.

- Seção Geológica transversal (1:200) com localização das amostras do Nível 15 - Travessa 2070, Mina São Bento

\section{Anexo 2:}

- Mapa Topográfico da região de Santa Bárbara_(1:10.000)com limites da área de trabalho e localização dos afloramentos descritos.

- Mapa Geológico (1:10.000) da área de trabalho, região de Santa Bárbara, Quadrilátero Ferrífero, Minas Gerais, Brasil.

- Seções Geológicas (1:10.000).

\section{Anexo 3:}

- Tabela 2 - Amostras, localização, lâminas e seções polidas

- Tabela 3 - Microscopia petrográfica

- Tabela 4 - Microscopia de minerais opacos 


\section{Índice de Tabelas}

Tabela 1 - Resumo das descrições de afloramentos.

Tabela 5 - Resultados das análises realizadas por FRX.

Tabela 6 - Resultados de análises para ETR.

Tabela 7 - Análises realizadas por Fire Assay. 


\section{1-Introdução}

A área de trabalho localiza-se no greenstone belt Rio das Velhas na região do Quadrilátero Ferrífero (QF), MG (Schorscher 1976 a, 1976 b, 1978, 1979, 1992; Schobbenhaus et al. 1988; Inda et al. 1984; Schorscher et al. 1986, 1990), e compreende a mina de ouro São Bento e arredores.

Os ambientes greenstone belt mundialmente reconhecidos como importantes metalotectos auríferos, sempre foram alvos de estudos metalogenéticos e discussões controversas, por sua riqueza e complexidade geológica, decorrente dos múltiplos eventos que sofreram desde suas origens arqueanas a, eventualmente, paleoproterozóicas. Assim, formaram-se opinióes diferentes e conceitos muito distintos baseados em processos ora deformacionais (Hodgson, 1989), metamórficos (Groves e Batt, 1984), hidrotermais exalativos sinsedimentares (Hutchinson, 1973) e magmáticos (Mason e Helmstaedt, 1992) como controladores principais ou mesmo exclusivos das mineralizações de ouro. Apenas poucos pesquisadores desde Hutchinson et al. (1971), Fripp (1976 a, b), Hutchinson e Burlington (1984) e Hutchinson (1993) claramente defendem a interação de múltiplos fatores seguindo linhas de pensamento favorecendo um modelo singenético modificado.

Para a mina São Bento as hipóteses sin e epigenéticas já foram propostas e discutidas em conformidade com os respectivos modelos metalogenéticos da literatura internacional e com base em trabalhos de geologia de mina, mais recentemente por Martins Pereira (1995) e estudos mineralógico-petrológicos e geoquímicos (Valladares, 2000) com ênfase em inclusões fluidas (Lobato e Vieira, 1998; Lobato et al., 1998). Entretanto, continua persistindo uma considerável carência de dados geológicos regionais e locais lito-estratigráficos e estruturais, não estando ainda definidas questões fundamentais como, por exemplo, da disposição normal ou invertida da sucessão mineralizada e suas rochas encaixantes próximas. Também faltam estudos detalhados e comparativos afins mineralógico-petrográficos (e calcográficos), texturais-paragenéticos e estruturais, além de geoquímicos multielementares. A proposta desta pesquisa sobre a mina São Bento inclui:

- detalhamentos de campo regionais e locais de superfície e subsolo com amostragens sistemáticas de várias interseções laterais e down-dip contínuas e completas dos horizontes mineralizados, de estéreis intercalados e rochas encaixantes, $\mathrm{e}$

- estudos mineralógico-petrográficos diversos, calcográficos e geoquímicos globais multielementares de rochas e minérios.

Esse projeto de mestrado insere-se na principal linha de pesquisa do orientador e sua equipe sobre a evolução crustal precambriana, petrogênese e metalogênese de partes SE do Cráton do São Francisco. 


\subsection{Localização e Acesso}

A mina de ouro São Bento situa-se no distrito de Barra Feliz, Município de Santa Bárbara, Estado de Minas Gerais, a aproximadamente $43^{\circ} 28^{\prime \prime}$ de longitude oeste e $19^{\circ} 58^{\prime \prime}$ de latitude sul. As sedes municipais mais próximas são Barão de Cocais e Santa Bárbara, situadas, respectivamente, a cerca de $4 \mathrm{Km}$ e $10 \mathrm{Km}$ da mina. Da capital do Estado, Belo Horizonte, são cerca de $100 \mathrm{Km}$ por rodovias asfaltadas, BR-262 e MG-436 (Figura 1). 


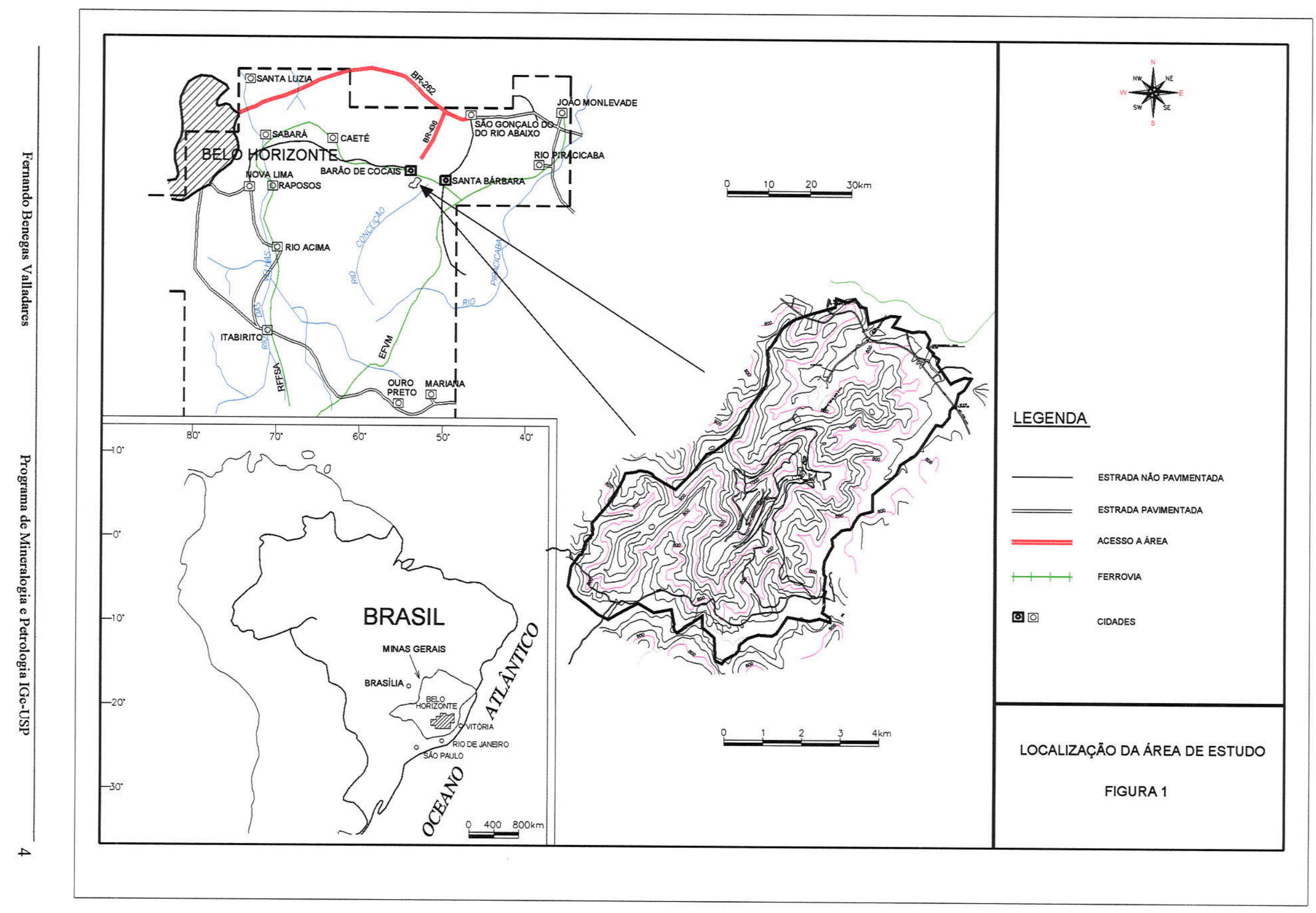




\subsection{Objetivos}

A pesquisa objetiva contribuir aos conhecimentos da petro-metalogênese da mineralização de ouro da mina São Bento, no contexto da evolução crustal precambriana policíclica de uma parte do greenstone belt Rio das Velhas, arqueano, com retrabalhamentos proterozóicos superimpostos. Para tanto serão realizados:

- Trabalhos de campo com amostragens sistemáticas de superfície e subsolo incluindo análises estruturais;

- Estudos detalhados da mineralização e rochas encaixantes da mina São Bento visando a caracterização petro-metalogenética pormenorizada de todas as unidades litológicas (metassedimentares, metaígneas, de zonas de falhas e veeiros);

- Estudos geoquímicos multielementares globais dos protominérios e minérios de ouro, e das rochas estéreis intercaladas e encaixantes, $\mathrm{e}$

\subsection{Materiais e métodos}

A pesquisa foi baseada em estudos bibliográficos, trabalhos de campo e no estudo petrometalogenético sistemático da uma coleção de amostras feitas pelo orientador em etapas prévias da pesquisa (Nível 15), e outras integradas pelo autor durante o período em que realizou estágio e desde que trabalha como geólogo de mina da São Bento Mineração S/A (Anexo 1).

As amostragens no subsolo foram realizadas de forma que os quatro horizontes mineralizados da Formação Ferrífera São Bento Oeste, Middle (ou do Meio), São Bento e Leste fossem interceptados, assim como partes da Formação Grafitosa Basal a NW e da Formação Carrapato a SE.

\subsubsection{Trabalhos Preliminares}

- Levantamento bibliográfico segundo enfoques temáticos, regionais e locais.

- Revisão e integração dos dados anteriores, das etapas preparatórias deste projeto (Valladares, 2000), incluindo estudos petrográficos das coleções de amostras e lâminas já disponíveis.

Preparação das etapas de campo, com fotointerpretações detalhadas convencionais, além de mapas geológicos. 


\subsubsection{Trabalhos de Campo}

- Mapeamento lito-estrutural em escala 1: 10.000 da área de estudo (Anexo 2).

\subsubsection{Estudos Laboratoriais}

- Descrições macroscópicas, seleção de amostras e definição dos roteiros analíticos e das respectivas preparações em cada caso;

- Preparações e estudos microscópicos petrográficos e calcográficos detalhados de lâminas delgadas, delgadas polidas e seções polidas.

- Preparação e análises geoquímicas multielementares (elementos maiores e traços) de amostras globais de rochas e minérios via fluorescência de raios $\mathrm{X}$ e espectrometria de massa com fonte de plasma indutivamente acoplado (ICP-MS).

- Análise individual e comparativa e tratamento automático dos dados geoquímicos globais.

- Tratamento automático dos dados de campo para confeç̧ão de mapas, perfis regionais e seções geológicas na mina assim como dos dados estruturais utilizando o programas específico (Dip's da RockScience Software).

\subsubsection{Trabalhos Finais}

- Integração, análise conjunta de todos os resultados e interpretações finais.

- Redação e defesa da Dissertação de Mestrado. 


\section{Geologia Regional}

O Quadrilátero Ferrífero (QF) (Figura 2) localizado na porção sudeste do Cráton do São Francisco (CSF), numa região constituída de associações de rochas arqueanas e proterozóicas que, por sua riqueza mineral, particularmente de ouro, ferro e manganês tem atraído atenção de pesquisadores, exploradores e investidores desde o século XVIII, representa hoje uma das áreas clássicas da geologia precambriana do Brasil e do mundo. Neste período acumulou-se uma vasta bibliografia abordando virtualmente todos os aspectos da geologia fundamental e aplicada, cuja revisão pormenorizada foge aos objetivos deste trabalho. No que se segue será apresentado um breve resumo, mencionando os principais trabalhos regionais da borda SE do CSF e locais da mina São Bento e seus arredores.

Os trabalhos pioneiros e clássicos se devem a Eschwege (1817, 1822, 1832), Derby (1906), Harder e Chamberlein (1915), Freyberg (1932, 1934), Barbosa $(1935,1939,1954)$, Moraes e Barbosa (1939), Guimarães (1951, 1970), Pflug (1965, 1968), Pflug e Renger (1973) e Almeida (1977), entre muitos outros, e estabeleceram a bases, ainda válidas, da geologia da região.

$\mathrm{O}$ primeiro, e até hoje único mapeamento sistemático do QF realizado pelo United States Geological Survey (USGS) em cooperação com o Departamento Nacional de Produção Mineral (DNPM) entre 1946-1962, teve como objetivo principal a caracterização e quantificação das reservas de classe mundial de minérios de ferro desta região (síntese por Dorr, 1969). Neste projeto o QF foi mapeado em quadrículas individuais 1:25.000 e integrado em escala 1:150.000; os trabalhos de sínteses geológica e petrográficas foram publicados respectivamente por Dorr (1969) e Herz $(1970,1978)$. A região da mina São Bento compreendida na quadrícula Sta. Barbara foi mapeada em escala 1: 25.000 e descrita por Simmons (1968).

As rochas metassedimentares e vulcanosedimentares da região foram agrupadas em três unidades maiores, da mais antiga para a mais nova, denominadas e definidas como Serie Rio das Velhas, Minas e Itacolomi. Na Série Rio das Velhas Dorr et al. (1957) e Dorr (1969) descreveram rochas metavulcânicas, xistos, filitos, metagrauvacas e formações ferriferas do tipo Algoma (Grupo Nova Lima) como um ambiente eugeossinclinal de tipo Flysch e quartzitos e conglomerados (Grupo Maquiné) como depósitos molássicos.

As rochas granito-gnáissicas foram consideradas por Dorr (1969) como de origem intrusivas ígneas posteriores às unidades metassedimentares e vulcano-sedimentares.

Almeida (1976) e Schorscher (1976) reconsideraram a Série Rio das Velhas de Dorr (1965) como uma possível associação litoestrutural do tipo greenstone belt reinerpretando resultados anteriores da literatura e com base em novos dados. Em 1978, Schorscher descreveu os primeiros Komatítos spinifex e reconheceu a natureza vulcânica de um conjunto de rochas metaultramáficas que eram antes consideradas intrusivas mais jovens inclusive do que a Série Minas, redefinindo-o como 
unidade inferior denominada Grupo Quebra Osso do Supergrupo Rio das Velhas, que, dessa forma, compreenderia uma sucessão litológica essencialmente completa de um greenstone belt arqueano de tipo Barberton. (cf. Schorscher, 1979 a,b)

O Supergrupo Rio das Velhas foi então subdividido em 3 grupos (Schorscher, 1979 a,b; 1992; Schorscher et al., 1982; Inda et al., 1984) da base para o topo:

- Grupo Quebra Osso: rochas metaultramáficas vulcânicas, com intercalações de metassedimentos químicos (BIFs tipo Algoma e metacherts).

- Grupo Nova Lima: sequência de rochas sedimentares clásticas e químicas, representadas por xistos predominantemente máficos, metabasitos, formações ferríferas de fácies óxido, carbonato, silicato e sulfeto, conglomerados, xistos grafitosos, carbonáticos e tufáceos.

- Grupo Maquiné: unidade clástica, composta por quartzitos, quartzo xistos e conglomerados com piritas detríticas.

$\mathrm{O}$ metamorfismo geral no $\mathrm{QF}$ é de fácies xisto verde com intensidade crescente de $\mathrm{W}$ para $\mathrm{E}$; chegando a fácies anfibolito na região a E do QF (Schorscher, 1975; Rettinger et al., 1996; Rettinger, 1998).

Supergrupos Minas, Espinhaço e Itacolomi

A Série Minas (Barbosa, A. 1968; Dorr, 1969), hoje redefinida como Supergrupo (Inda et al., 1984), consiste, da base para o topo, numa sucessão clástica (Grupo Caraça) de quartzitos e metaconglomerados piritosos, auríferos e uraníferos, seguida por uma sequência de itabiritos, formações ferríferas do tipo "Lago Superior", de origens químicas (Grupo Itabira) e, finalmente, por uma associação clástico-química (Grupo Piracicaba), típica do paleoproterozóico.

Outras sequências quartzíticas da região centro leste do QF (a exemplo da Serra das Cambotas, Caraça e Itacolomi, entre outras), são, até hoje, assuntos de controvérsias, quanto as idades, posicionamentos estratigráficos, das correlações mútuas e com os supergrupos Minas e Espinhaço, tendo sido ainda atribuídas ao Grupo Tamanduá (Fm. Quartizito Cambotas) (Simmons e Maxwell,1961) e ao Grupo e a Série Itacolomi (Harder e Chamberlain,1915; Guimarães, 1931; Dorr, 1969; Costa e Romano, 1976). Sem maior relevância para o presente trabalho essas sequências não serão mais abordadas. 
Sob os aspectos temáticos são ainda fundamentais para a presente pesquisa obras sobre a natureza $\mathrm{e}$ origem de formações ferríferas bandadas arqueanas e proterozóicas no contexto global - aspectos que foram discutidos por James (1954), Goodwin (1962) e Gross (1965), entre outros, assim como os estudos e revisões dos principais modelos genéticos para depósitos auríferos em BIF de greenstone belts arqueanos dentre os quais se destacam Hutchinson (1973, 1993), Fripp (1976 a, b), Kerrich e Fryer (1979), Phillips et al. (1984), Groves et al. (1985), entre outros.

Para a mineralização de ouro da mina São Bento dois modelos metalogenéticos principais são controvertidamente discutidos na literatura: o modelo singenético - hoje singenético modificado e o modelo metamórfico-estrutural.

O modelo singenético (singenético modificado) foi desenvolvido, principalmente por Hutchinson (1973, 1993) e Hutchinson e Burlington (1984). É baseado na origem primária das mineralizações auríferas por contribuição sedimentar-química e/ou vulcano-exalativa, concomitante, e singenética à formação da pilha sedimentar/vulcano-sedimentar e sua diagênese. As protomineralizações assim formadas teriam sido posteriormente afetadas por metamorfismo, deformação e, eventualmente, magmatismo e fluidos magmáticos, obliterando, parcial a totalmente, as características primárias desses depósitos. Transformando-os por processos superimpostos variáveis e entre si diferentes, gerando novas assinaturas convergentes e mais próximas àquelas dos últimos e/ou mais intensos eventos que atuaram. As mineralizações econômicas assim, quase sempre, seriam provenientes da transformação de protominérios singenéticos. No QF foram dessa forma explicados os depósitos de ouro das minas do Faria (Moreschi 1972), Morro Velho (Ladeira, 1980), do Pari (Schorscher et al. 1986, 1991; Abreu, G. 1995) e São Bento (Valladares, 2000). Análogos recentes deste tipo de mineralização de ouro seriam os depósitos de sulfetos exalativos de tipo smokers de ambientes de fundo oceânico em processos de abertura tectono-magmáticos ativos (Rona e Scott, 1993).

O modelo metamórfico-estrutural, desenvolvido por Groves e Batt (1984), Hodgson (1989), Phillips e Groves (1983) e muitos seguidores, é internacionalmente hoje talvez mais aceito e predomina inclusive na interpretação dos depósitos de ouro do Q.F. Salienta os processos tectonometamórficos como mais importantes geradores de fluídos lixiviantes e/ou mineralizantes e respectivos condutos para os ambientes-armadilha deposicionais. Fluidos gerados pelo metamorfismo regional nos greenstone belts, em geral ricos em $\mathrm{CO}_{2}$, seriam os agentes de lixiviação e transporte do ouro para as zonas de cisalhamento, onde porções extensionais aliadas ou não a rochas encaixantes de composições apropriadas, por exemplo BIF agindo como filtros ou precipitadores químicos, criariam condições de deposição do metal. Ao ouro associar-se-iam, em proporções variáveis, sulfetos (pirita, arsenopirita, pirrotita, esfalerita, calcopirita, entre outros), e como principais minerais de ganga, quartzo, carbonatos, scheelita e, eventualmente, turmalina, seja em veios (em geral polideformados) e/ou como impregnações nas rochas encaixantes. 
No Q.F, muitos trabalhos recentes de enfoque estrutural, por exemplo de Belo de Oliveira (1986) nas mineralizações auriferas da região de Caeté, Martins Pereira (1995) na mina São Bento, Menezes (1996) na mina de Santana, Ribeiro-Rodrigues (1998) na mina de Cuiabá, e outros autores apoiados principalmente no estudo de inclusões fluidas, por exemplo Lobato e Vieira (1998) e Lobato et al.(1998), favorecem o modelo metamórfico estrutural epigenético. Salienta-se, entretanto, que alguns desses trabalhos surtem dúvidas. Assim, por exemplo Martins Pereira (1995), na mina São Bento, reconhece a pré-existência de um protominério estratiforme, embora favorece o modelo epigenético para os principais corpos de minério rico em lavra. Já num contexto muito mais interpretativo, Lobato e Vieira (1998) e Lobato et al. (1998) discutindo vários depósitos do QF, consideraram virtualmente todos como de origem epigenética. 


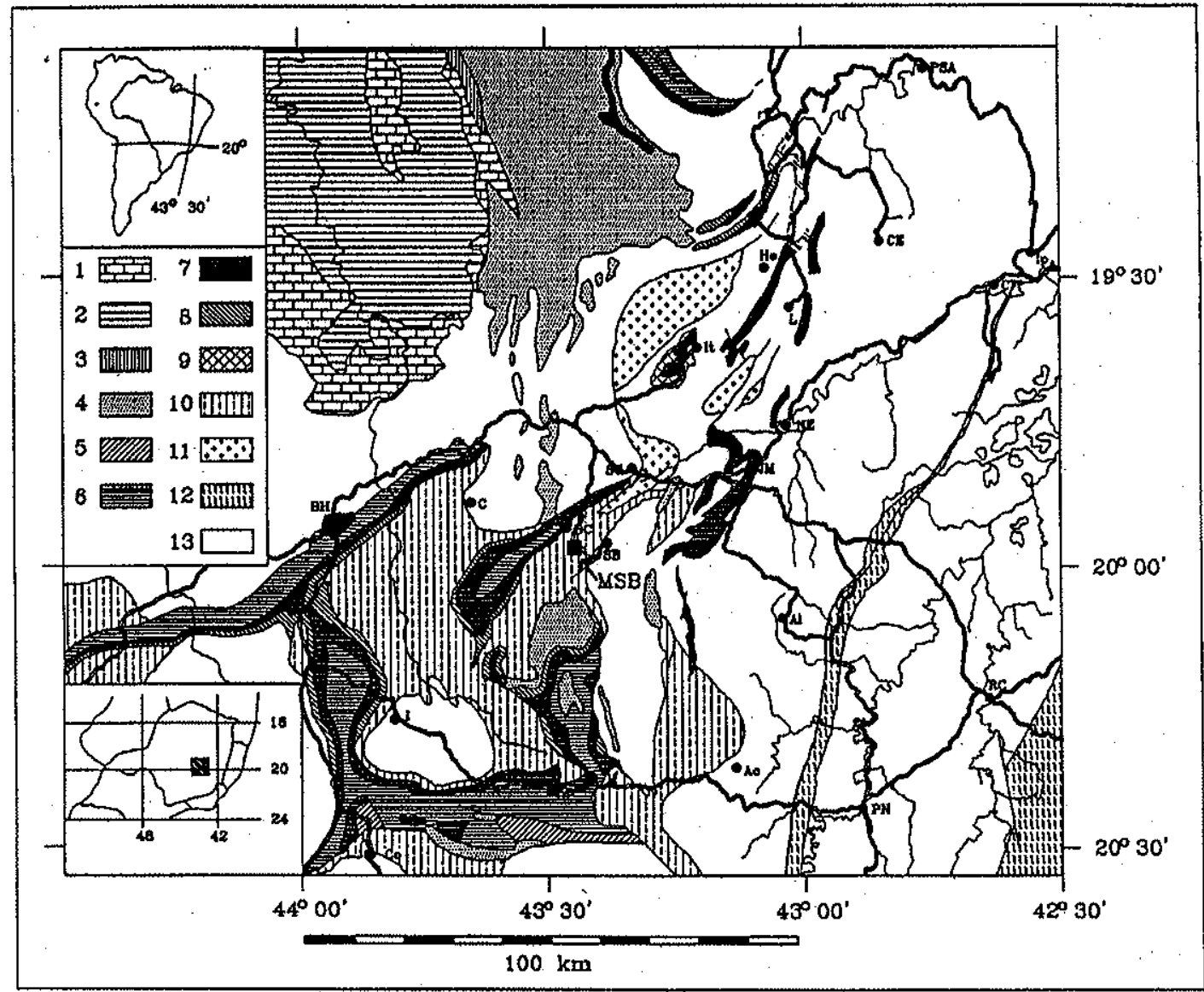

Figura 2 - Localização e contexto geológico da região da Mina São Bento (MSB).

Legendas: I a 3-Sgr. São Francisco (meso a neoproterozóico); 4-Sgr. Espinhaço (paleo a mesoproterozóico); 5 a 9-Sgr. Minas (paleoproterozóico); 10-greenstone belt/Sgr. Rio das Velhas (arqueano); 11-Metagranitóides Borrachudos; 12-Milonitognaisses, migmatitos e quartzitos; 13-Gnaisses graníticos, migmatitos e metagranitóides indiferenciados (arqueanos e proterozóicos) do Complexo Regional de Rochas sensu lato Graniticas.

Cidades: Ac-Acaiaca; Al-Alvinópolis; $\mathrm{BC}$-Barão de Cocais; BH-Belo Horizonte; C-Caeté; CECocais das Estrelas; CF-Coronel Fabriciano; Co-Congonhas: He-Hematita: 1-Itabirito; IpIpatinga; It-ltabira; JM-João Monlevade; L-Liberdade; M-Mariana: NE-Nova Era: OP.Ouro Preto; PN-Ponte Nova; PSA-Ponte de Santo Antònio; RC-Rio Cascca: SB-Santa Bárbara; SGSx̆o Gonçalo do Rio Abaixo.

Extraído e modificado de Schorscher (1992) 


\section{Trabalhos de campo}

Os trabalhos de campo na região maior e nos arredores da área do manifesto da mina São Bento tiveram por objetivo contribuir ao mapeamento regional de semidetalhe $(1: 10.000)$, além de estudos petrográficos, estruturais e metalogenéticos. Essa etapa foi iniciada com a compilação e análise dos levantamentos geológicos anteriores servindo de base para os trabalhos de campo e fotointerpretação.

A fotointerpretação foi uma atividade realizada de forma permanente, servindo para auxiliar a integração dos dados de campo e na análise de feições estruturais.

O mapeamento, em escala 1:10.000, seguiu o método clássico de descrição de afloramentos, com ênfase para os aspectos litológicos, estratigráficos e sedimentológicos, do magmatismo, estruturais (estruturas primárias e tectôno-metamórficas), metamórficas e metalogenéticos.

A reunião das informações coletadas e compiladas a partir de trabalhos de mapeamento realizados anteriormente pelos geólogos da São Bento Mineração S/A permitiu a elaboração de um mapa em escala 1:10.000 e respectivas seções geológicas (Anexo 2). Resumo com descrição dos afloramentos na Tabela 1 .

\subsection{Litoestratigrafia}

As unidades litoestratigráficas reconhecidas na área de estudo englobam gnaisses migmatitos e metagranitóides TTG (tonalito-trondhjenito-granodioríticos) da borda $\mathrm{W}$ do domo de Santa Bárbara, o Supergrupo Rio das Velhas, intrusivas básicas, coberturas lateríticas e depósitos aluvionares. Aqui serão tratadas apenas as rochas do Supergrupo Rio das Velhas.

Foram reconhecidas rochas metaultramáficas pertencecntes ao Grupo Quebra Osso, e metassedimentos clásticos e químicos do Grupo Nova Lima, entre estas, possíveis metaturbiditos, níveis de formações ferríferas intercalados e metaconglomerados intraformacionais de deslizamentos e tectônica sinsedimentares.

As rochas metassedimentares químicas associam-se com sericita-clorita xistos grafitosos/ou carbonáticos e xistos grafitosos.

\subsection{Estruturas}

A principal feição estrutural observada na área é representada pela foliação/xistosidade de direção NE e mergulho para SE, resultantes de uma fase deformacional de carater compressional, com transporte tectônico de $\mathrm{E}$ para W, deduzido a partir de lineações de estiramento. Este evento gerou 
as falhas de empurrão de direção similar à foliação regional e, que em geral, marca o contato entre as unidades, as quais são deslocadas por falhas de direção NW-SE. São observadas clivagens (fratura e crenulação) de direções NS e EW.

Sob aspectos litoestratigráficos e estruturais regionais tem-se na parte $\mathrm{E}$ da área mapeada a disposição estrutural invertida do Grupo Quebra Osso basal do Supergrupo Rio das Velhas sobre o Grupo Nova Lima, assim como das rochas do TTG do Domo de Santa Bárbara, sobre o Grupo Quebra Osso. Entretanto, essas relações estruturais regionais invertidas, embora possíveis e até prováveis, não podem ser confirmadas com segurança apenas com base nos dados litoestruturais levantados para a sucessão local das unidades litológicas informais definidas e mapeadas na área do manifesto e no subsolo da mina São Bento. Para a decisão, quanto a disposição estratigráfica normal ou invertida das rochas e minérios da mina São Bento, ainda serão necessários dados complementares. 


\section{Geologia Local}

O pacote de metassedimentos clásticos e químicos que ocorrem nas proximidades da mina São Bento faz parte do Grupo Nova Lima, Supergrupo Rio das Velhas (Dorr, 1969; Schorscher, 1979). $\mathrm{Na}$ área do manifesto foram individualizadas quatro unidades litoestratigráficas principais (Figuras 3 e 4), mapeáveis na escala 1:25.000, e de oeste para leste designadas informalmente e sem conotação estratigráfica.: Formação Ferrifera Inferior (FFI), Formação Grafitosa Basal (FGB), Formação Ferrífera São Bento (FFSB) e Formação Carrapato (FC). Foram caracterizadas por Abreu et al. (1988) e Martins Pereira (1995), conforme abaixo resumido e complementado com algumas observações deste trabalho.

O termo "fácies" é aqui empregado no sentido da associação mineralógica.

\subsection{Formação Ferrífera Inferior}

Melhor exposta na porção NW da área, é constituída por formaç̃̃es ferriferas bandadas fácies óxido com magnetita, silicato e carbonato. A mineralogia básica é representada por quartzo, magnetita, clorita e carbonato.

\subsection{Formação Grafitosa Basal}

É constituída por clorita-xistos grafitosos e carbonáticos, em geral finamente laminados, de coloração cinza-escura a negra. A laminação pode tornar-se quase imperceptível à vista desarmada em razão de granulometria muito fina. Os leitos mais ricos em quartzo marcam a estratificação. Intercalações quartzo-carbonáticas, de espessura milimétrica a decimétrica.

Uma característica marcante destes xistos é a presença de concreções nodulares de sulfetos (pirita e subordinadamente pirrotita) contendo, eventualmente, algum ouro, que ocorrem principalmente no contato com a unidade ferrífera superior, sendo que o contato em si é direto e brusco. 


\subsection{Formação Ferrífera São Bento}

A Formação Ferrífera São Bento é a portadora da mineralização. Sua espessura média é de cerca de $120 \mathrm{~m}$., constituindo-se essencialmente num pacote de formações ferríferas bandadas de fácies óxido, carbonato, silicato, sulfeto e mistas, que se apresentam como uma sucessão de estratos milimétricos a centimétricos, mostrando ainda, intensas variações faciológicas verticais e laterais. São formados, como minerais principais por quartzo, Fe-carbonatos (ankerita e siderita), magnetita, estilpnomelana e clorita e, subordinadamente, de sulfetos, grafita e scheelita.

O bandamento é marcado por leitos de cores claras e escuras. Os primeiros de tom geralmente creme, são constituídos por quartzo e Fe-carbonatos, ao passo que os leitos escuros de tonalidade esverdeada são ricos em clorita e estilpnomelana e os de tom cinza-escuro, ricos em magnetita ou grafita.

Metassedimentos clásticos de granulação fina (metapelitos a metasiltitos) caracterizam-se petrograficamente como clorita-quartzo xistos grafitosos e mica (sericita) xistos quartzocarbonáticos e são encontrados intercalados aos níveis de formações ferriferas.

Por suas características distintas e importância econômica a Formação Ferrífera São Bento foi subdividida (informalmente e sem conotações estratigráficas) em dois membros:

O Membro Ferrífero Basal, hospedeiro da mineralização de ouro, é caracterizado pela heterogeneidade litológica, pois além de BIF, estão presentes intercalações de metassedimentos clásticos finos - xistos grafitosos e carbonáticos. A mineralização de ouro ocorre em 4 horizontes denominados: Oeste, Middle (ou do Meio), São Bento e Leste separados por intercalações estéreis (Figura 4).

O Membro Ferrífero do Topo é estéril, homogêneo, constituído por BIF de fácies óxido, silicato e carbonato, ocorrendo em proporções que variam, vertical e lateralmente, possuindo cerca de 80 metros de espessura média.

\subsection{Formação Carrapato}

Segue-se para SE sobre a Formação Ferrífera São Bento. É composta por uma sequência de mica xistos variando de cinza-claros a escuros. São observadas também metagrauvacas, quartzo xistos, xistos carbonáticos ou grafitosos, além de horizontes de BIF de fácies carbonática e silicática, eventualmente com algum ouro. 


\subsection{Rochas Metabásicas}

Rochas metaígneas (também designadas por diques máficos, Figura 3) básicas foram observadas em furos de sondagem, nas escavaç̌es da mina e nos afloramentos da região. Próximos aos contatos apresentam granulação fina, passando rapidamente a média em direção ao centro dos corpos representados por diques e soleiras.Elevadas proporções de anfibólios, epídoto e clorita e carbonatos conferem às rochas uma coloração verde, ocorrendo, ainda, carbonato, plagioclásios saussuritizados e quartzo. $\mathrm{O}$ metamorfismo é de fácies xisto-verde baixo (antes da ocorrência da biotita). 


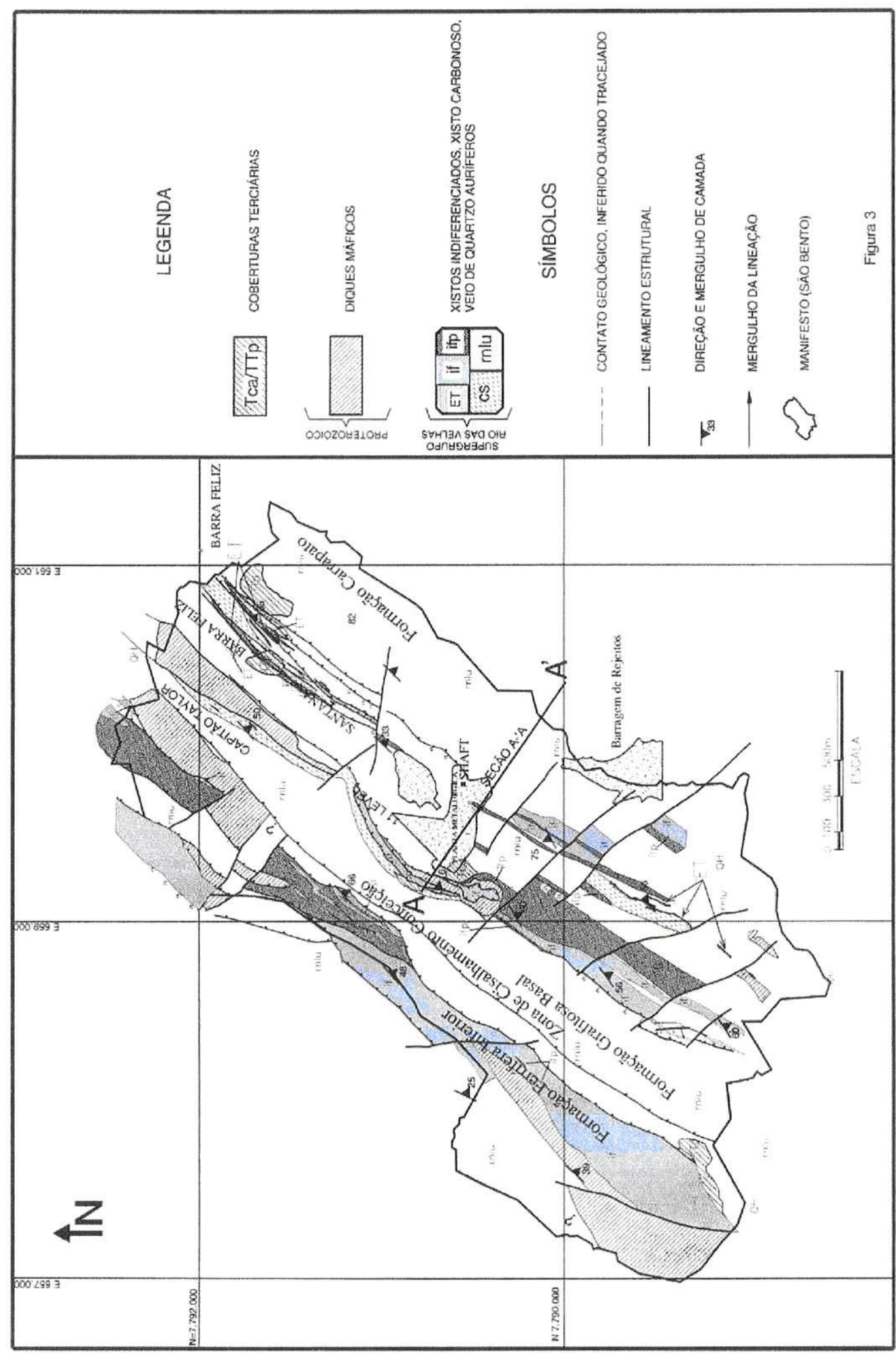

Figura 3: Mapa geológico do manifesto da mina São Bento 


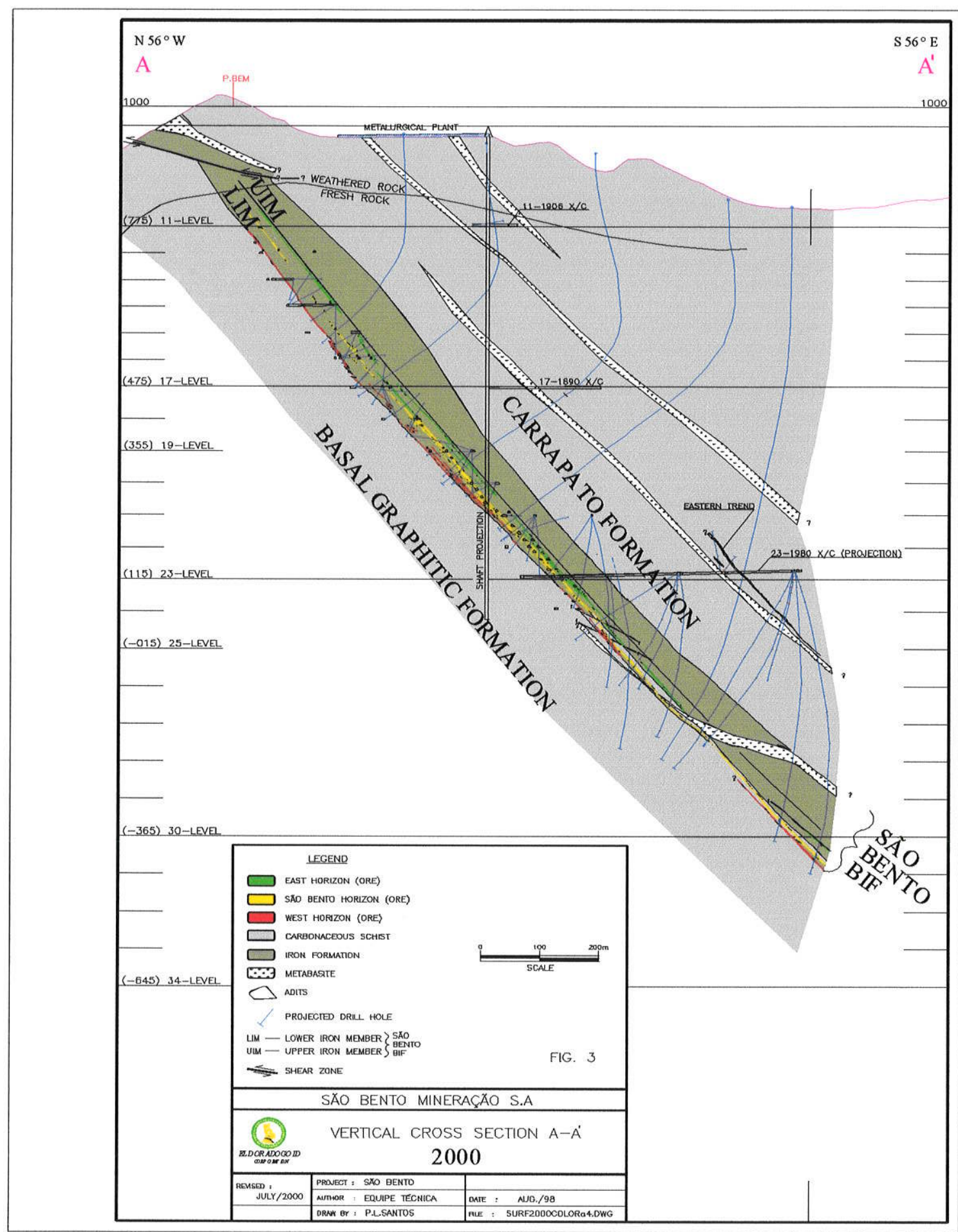

Figura 4: Seção geológica $A-A$ '. 


\section{Geologia Estrutural}

A mina de São Bento está disposta, de forma aproximada, na zona de charneira do anticlinal de Conceição de Dorr (1969) denominada por Martins Pereira (1995) como Zona de Cisalhamento de Conceição. A estrutura na área da mina é, aparentemente, homoclinal cuja orientação da foliação é de N30-35E/50-55SE.

Os corpos de minério da Mina São Bento estão inteiramente associados à sequência de formação ferrífera bandada e xistos que ocorrem na porção basal da Formação Ferrífera São Bento (Figura 4) caracterizando o depósito como sendo stratabound. Constituem horizontes litoestratigráficos bem definidos, geralmente se apresetando de forma lenticular, concordantes ao bandamento/acamamento, que é coincidente com a foliação principal (Diagrama 1). Os horizontes, internamente, apresentam feições transgressivas ao bandamento.

Como descrito por Martins Pereira (1995) os horizontes Oeste e Middle convergem em profundidade e na direção, e os horizontes São Bento e Leste mostram a mesma tendência.

As camadas apresentam, de forma geral, continuidade tanto lateral quanto ao longo de seu mergulho. O contato entre as unidades é brusco, marcado por intenso grau de milonitização.

Estruturas primárias, como o acamamento nos xistos e o bandamento nas formações ferríferas estão bem preservadas. A lineação de estiramento principal é paralela ao mergulho da foliação S50-55E mas apresenta desvios menores para E-NE e um subgrupo isolado e lineações subhorizontais para SW (Diagrama 2). Essas feições lineares menores, são paralelas respectivamente às lineações principais do Supergrupo Espinhaço e Minas

A coleta de dados estruturais concentrou-se nos níveis $25,26,27$ e 28 . 

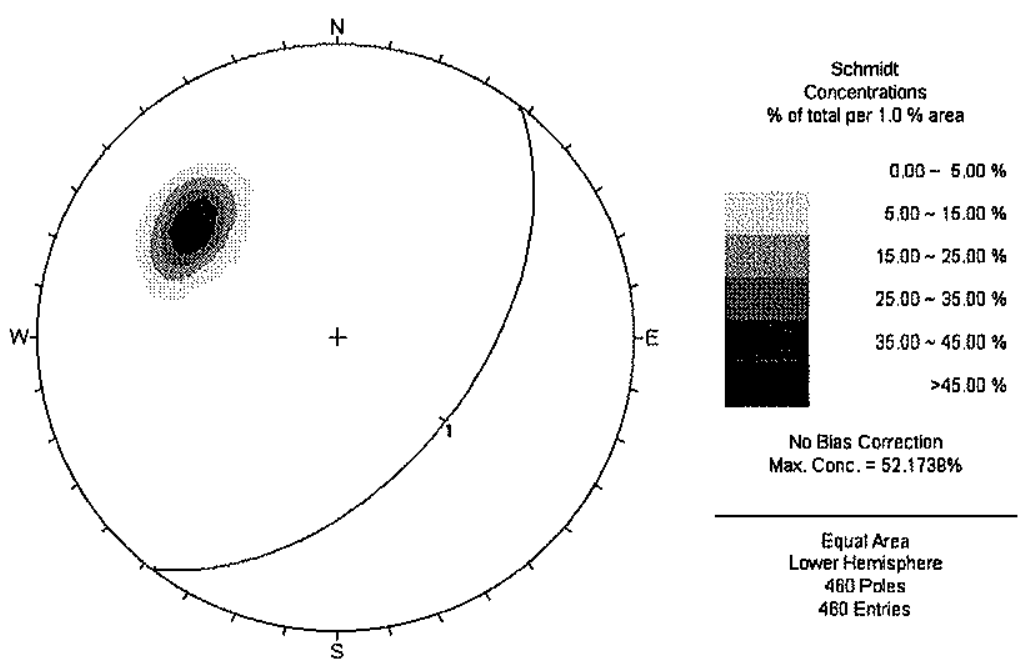

Diagrama 1.Frequência de polos da foliação principal. Máximo em 132/58.
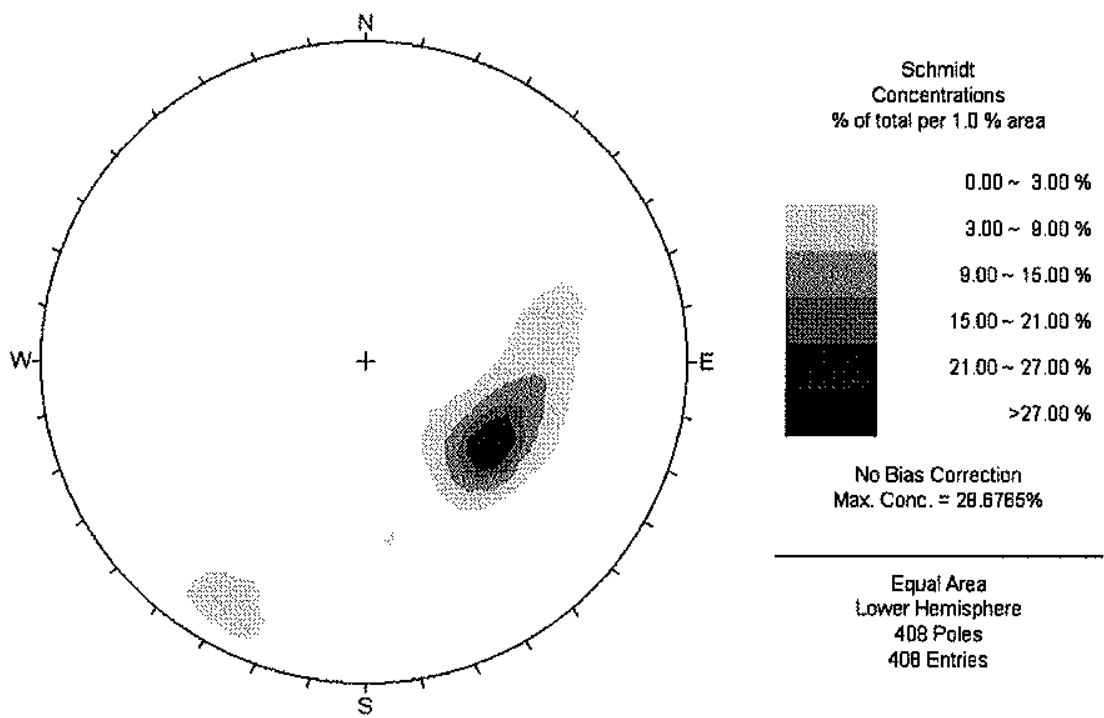

Diagrama 2 Frequência do rumo do caimento de lineações de estiramento. 
Os dobramentos observados variam desde dobras abertas até dobras apertadas a isoclinais simétricas a assimétricas-(Foto 1). O plano axial dos dobramentos é, quase sempre, coincidente com a foliação. A orientação das charneiras é em geral nordeste (Diagrama 3).

É comum a observação do rompimento dos flancos de dobras, como resultado da diferença de competência relativa dos materiais aos esforços
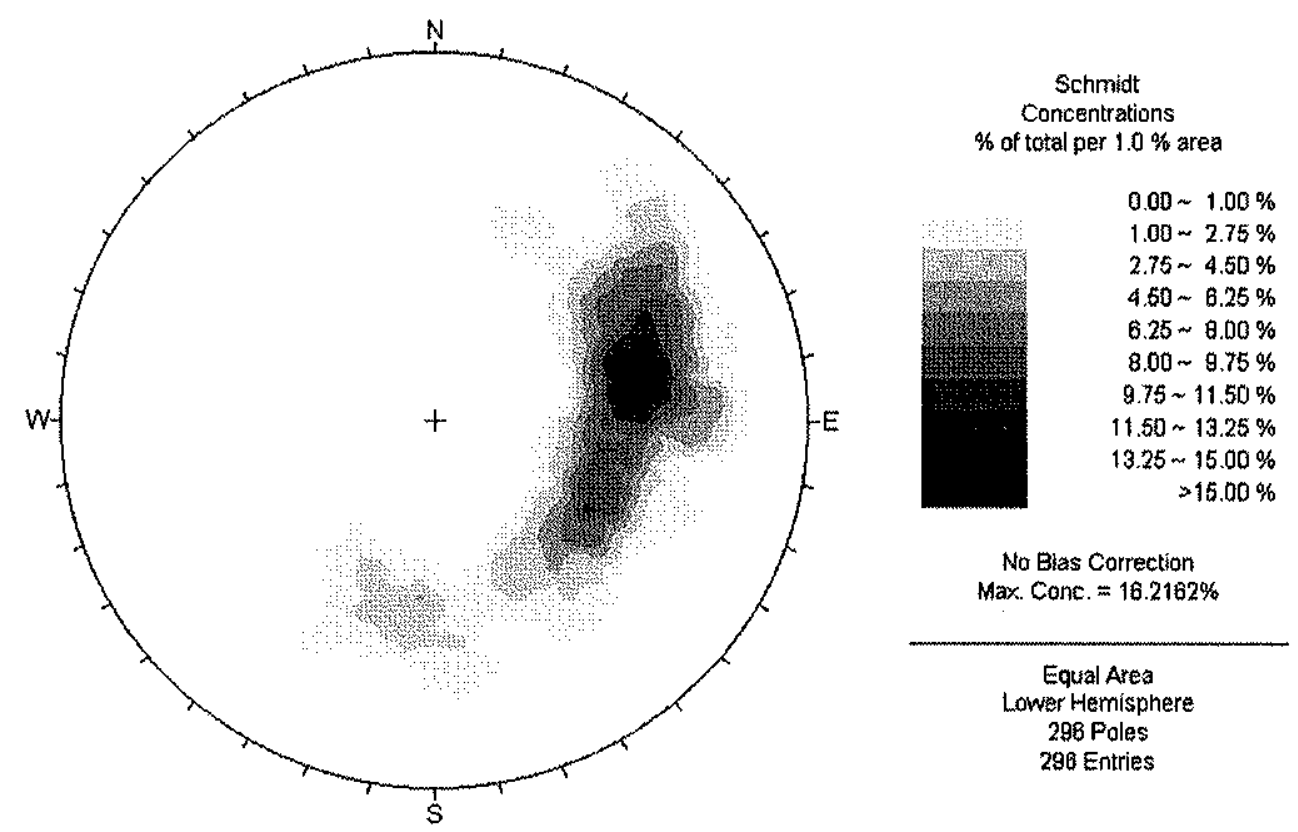

Diagrama 3. Direção dos eixos de dobras em formações ferríferas da Mina São Bento. Ponto máximo em $77 / 45$. 


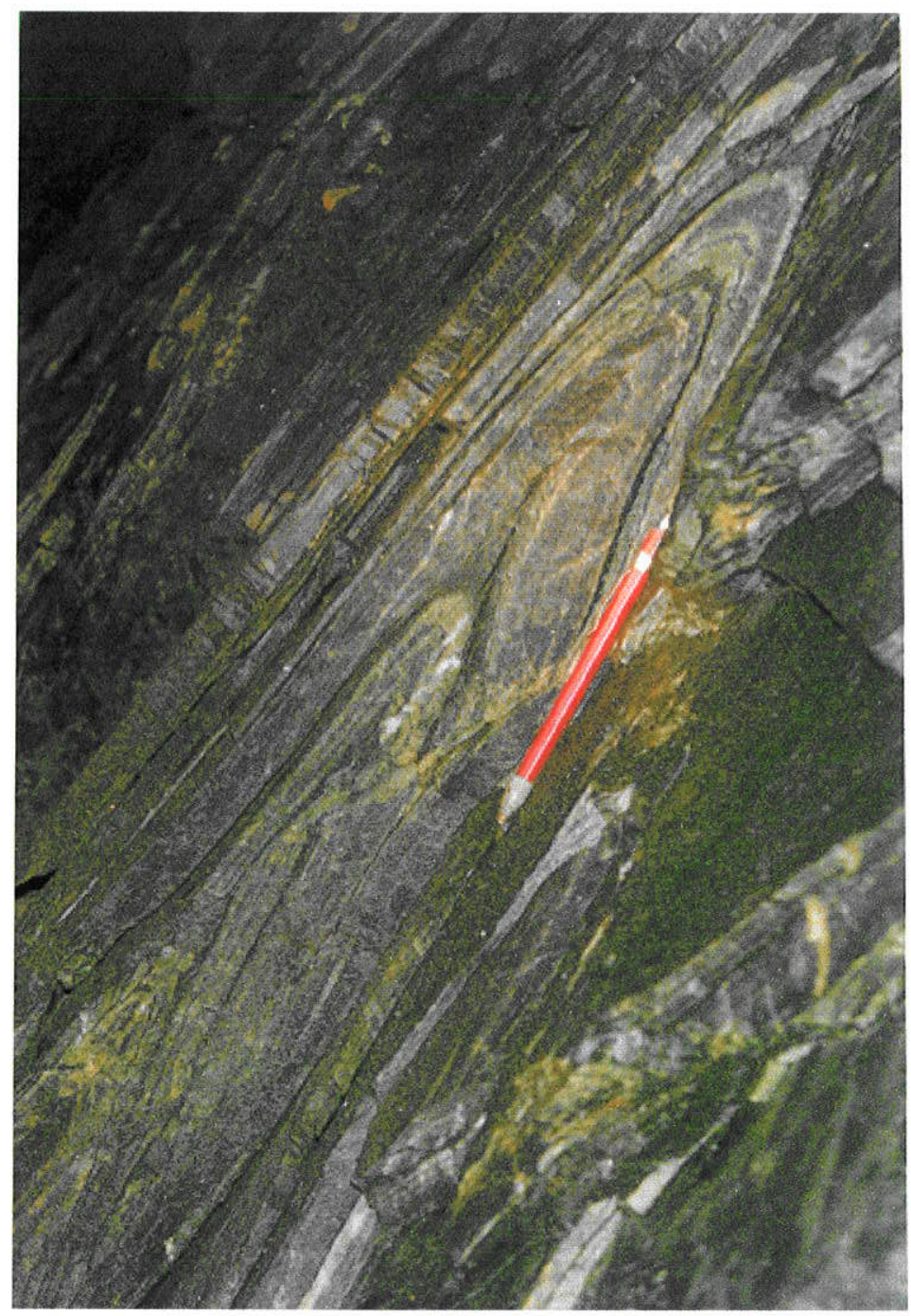

Foto 1: Dobra isoclinal assimétrica em formação ferrífera bandada fácies óxido. Nível 24, $1^{\circ}$ interdrive sul (Foto: Juliano E. Ferreira).

Zonas de cisalhamento ocorrem dispostas oblíquamente à direção da foliação e geram, por vezes, dobras de arraste nos locais de maior intensidade de deformação.

Como já descrito por Martins Pereira (1995) essas zonas de cisalhamento ocorrem também cortando os horizontes mineralizados causando tanto seu rompimento quanto sua duplicação (Foto 2).

Característica marcante é a presença de veios de quartzo, por vezes sulfetados (não auríferos), associados a estas zonas. 


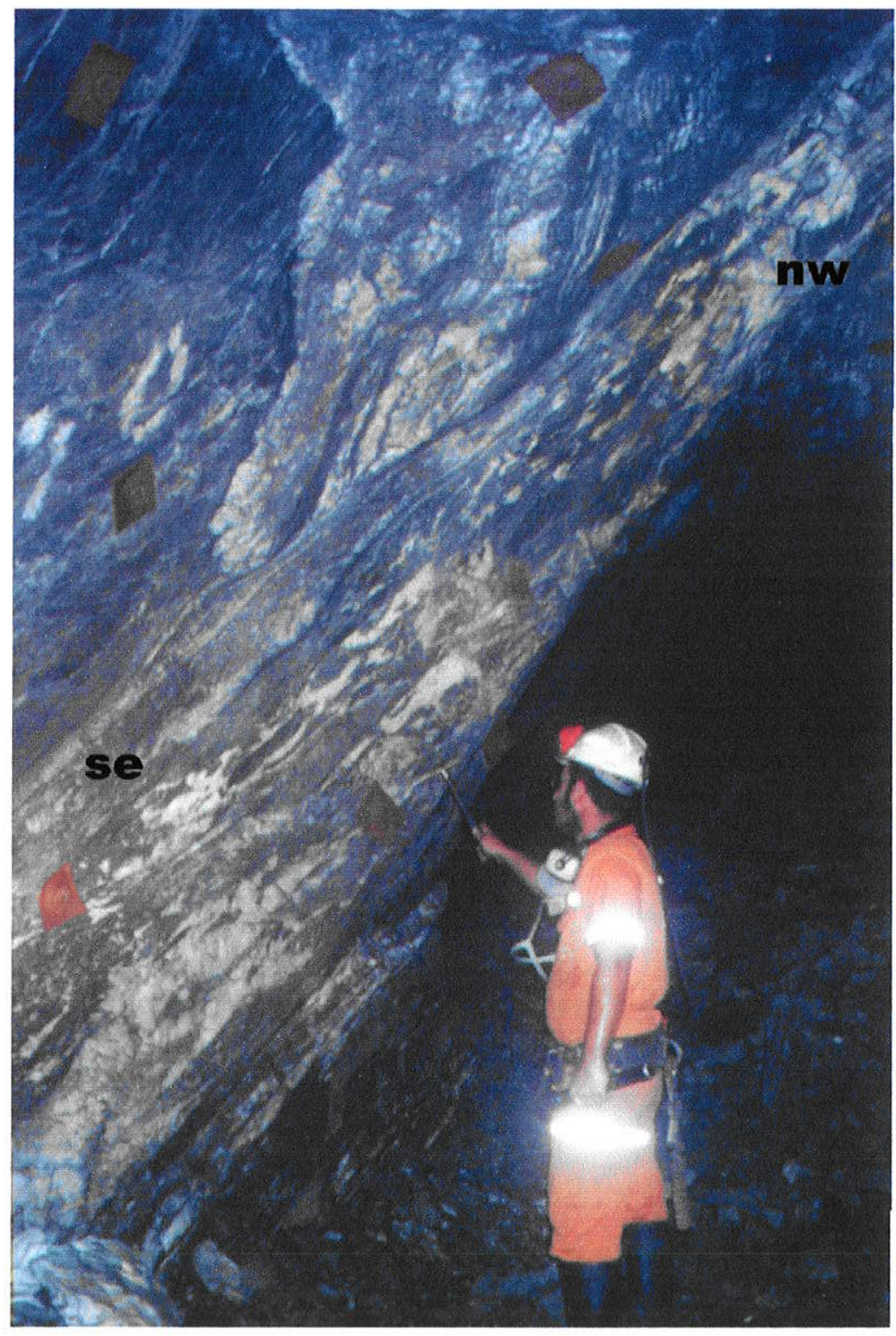

Foto 2: Falha de orientação aproximada norte-sul truncando oblíquamente a zona mineralizada. Nível $25,3^{\circ}$ interdrive sul. 
A mineralização sulfetada de ouro, que, outrossim, possui propriedades litológicas, estratigráficas e estruturais bastante constantes e regulares (Foto 3), localmente apresentam feições transgressivas, entre estas veios de quartzo sulfetados oblíquamente entrecortantes às formações ferriferas e, como descrito por Martins Pereira (1995), podem estar dispostos echelon (Fotos 4 e 5).

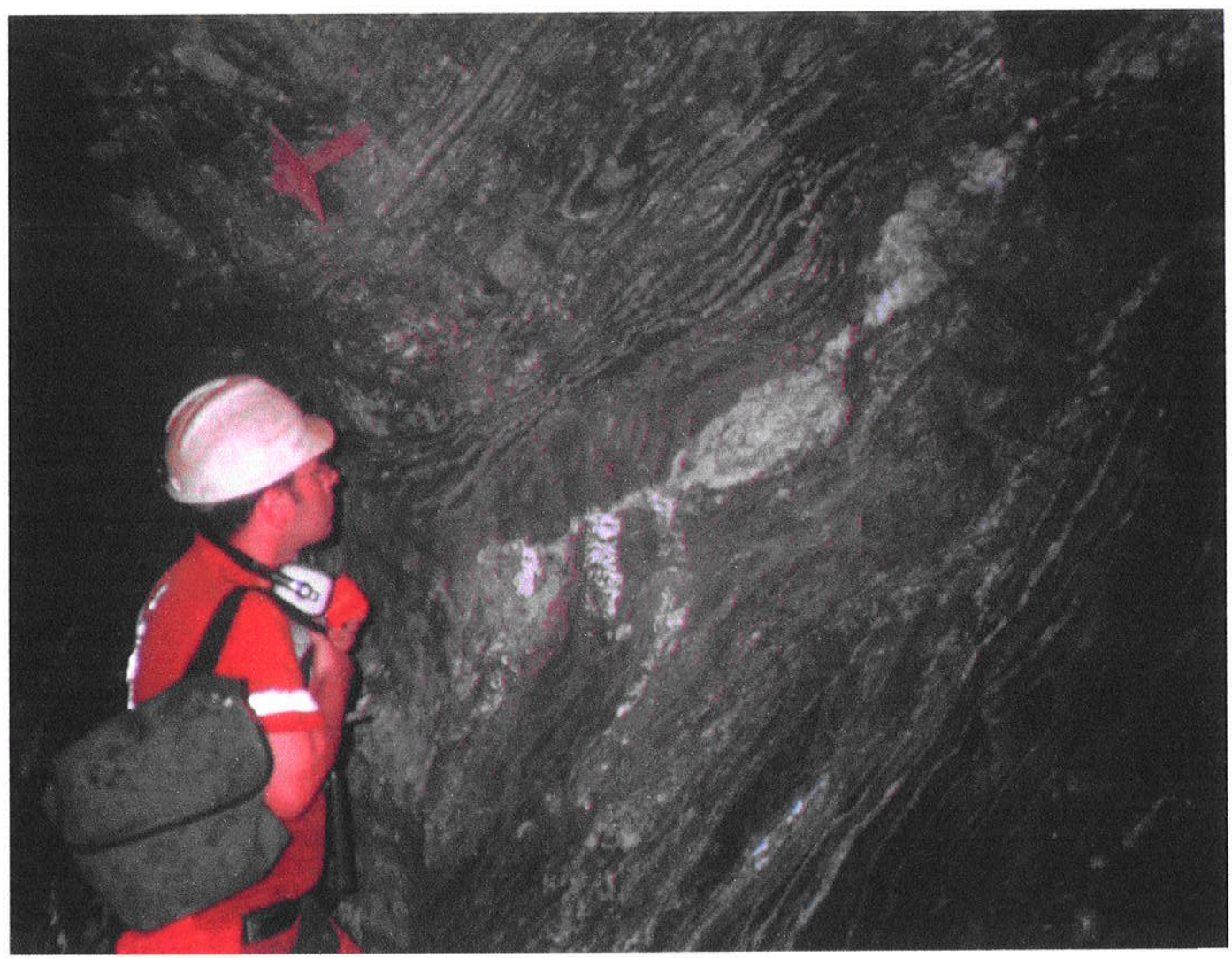

Foto 3: Veios de quartzo boudinados paralelos ao bandamento dos BIF de fácies sulfeto. Na porção inferior e superior da foto observa-se o bandamento do BIF de fácies óxido/silicato. Nível $25,1^{\circ}$ interdrive norte. Largura da foto $2,5 \mathrm{~m}$.. 


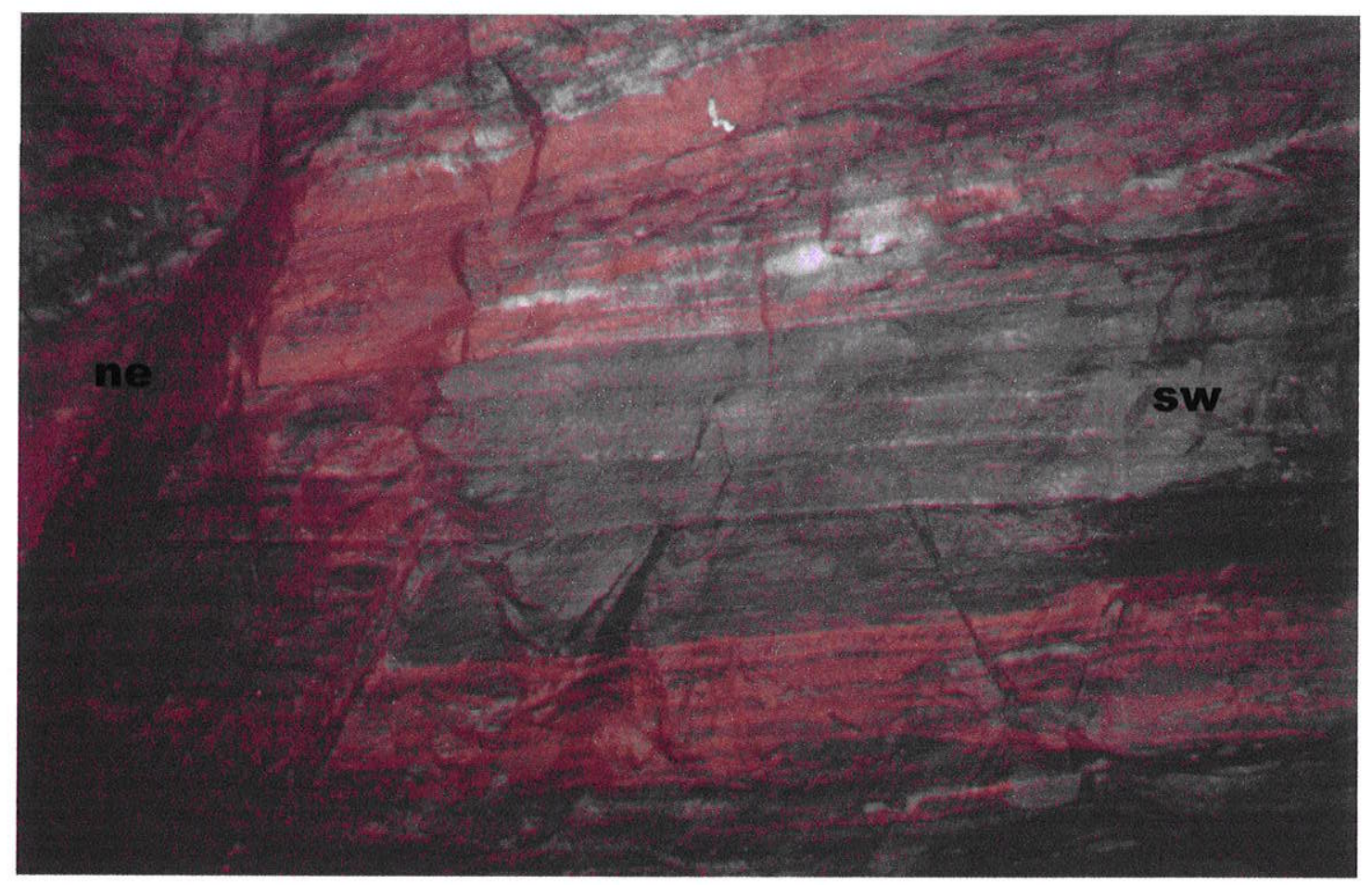

Foto 4: Veios de quartzo sulfetados dispostos em sistema echelon truncando oblíquamente a forrmação ferrífera composta por bandas regulares quartzo-carbonáticas e de magnetita.. Largura da da foto 2,5 metros. Nível 25 Reef Drive sul. 


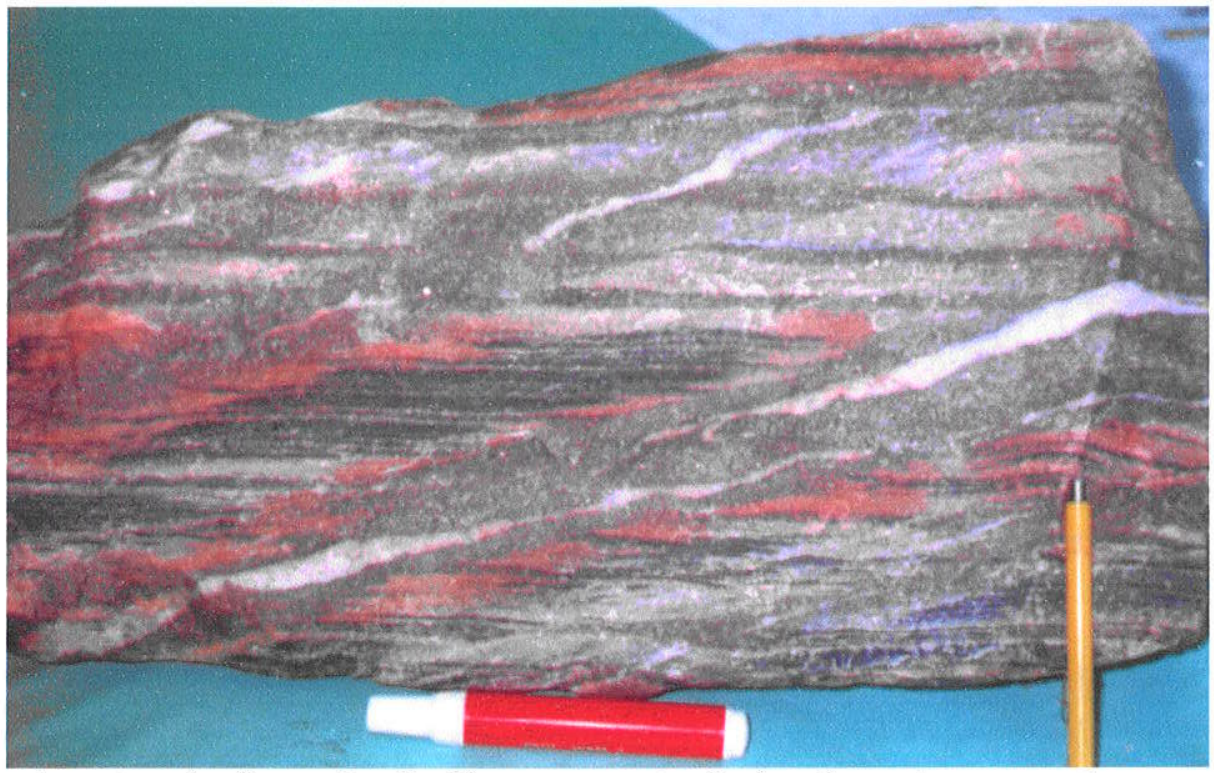

Foto 5: Amostra de formação ferrífera apresentando bandamento composto por carbonato e magnetita, truncado por veios quartzo-sulfetados dispostos em echelon.

A análise dos dados estruturais e dos indicadores cinemáticossugerem atuação de esforços compressivos e transporte tectônico de SE para NW em rampas frontais e laterais, estando relacionados à foliação e a lineação de estiramento mineral.

Dobras com eixo de direção geral NE-SW apontam para um encurtamento na direção ESE-WNW.

Rompimentos e/ou duplicações dos corpos de minério estão associadas a fraturas/falhas com direção geral NW, representando, estruturas resultantes de um comportamento menos dúctil. 


\section{Petrografia}

O presente capítulo é dedicado à descrição das características petrográficas tanto das rochas encaixantes da mineralização, estéreis intercaladas e do minério.

As litologias das amostras coletadas com sua localização são apresentadas no Anexo 3, Tabela 2.

Os estudos microscópicos tiveram por finalidade a análise paragenética-textural e micro-estrutural das associações de minerais de minério e de ganga para verificar e caracterizar diferentes fases/pulsos de mineralização aurífera. As paragêneses de sulfetos foram analisadas em relação aos óxidos dos BIF e as paragêneses de minério (sulfetos e óxidos) em conjunto, em relação as paragêneses de ganga nos minérios e nas rochas encaixantes.

Atenção especial foi dada a eventuais alterações hidrotermais de contato nas rochas encaixantes com a proximidade dos minérios.

Foram descritas 64 lâminas delgadas, 12 lâminas delgadas polidas e 20 seções polidas. As descrições são resumidas no Anexo 3, nas tabelas 3 e 4 .

\subsection{Formação Grafitosa Basal}

Os principais minerais são quartzo, carbonato, clorita e sericita. Os minerais subordinados são pirita, pirrotita e rutilo. Esses minerais associam-se em proporções variadas de modo a compor leitos que se alternam formando bandas, por vezes boudinadas e/ou dobradas (Fotomicrografia 1a). A textura geral é grano-lepidoblástica.

A associação quartzotcloritatsericita é característica do metamorfismo de baixo grau ou xisto verde (Winkler, 1977).

\subsection{Horizontes estéreis intercalados}

São compostos por BIF de fácies óxido, carbonato e silicato, além de clorita xistos grafitosos e carbonáticos, além de sericita-xistos e clorita-sericita xistos, todos com teores variáveis de quartzo. A mineralogia principal dos BIF compreende quartzo, carbonato, magnetita e clorita variando de acordo com as respectivas fácies, apresentando ainda teores menores de sericita e muscovita. A textura geral é granoblástica.

Quartzo, carbonato, clorita e sericita predominam nos xistos, ocorrendo, subordinadamente pirita. O quartzo apresenta textura de recristalização poligonal fina e, associado em proporções variáveis a clorita e a sericita definem o bandamento. A textura geral é grano-lepidoblástica 


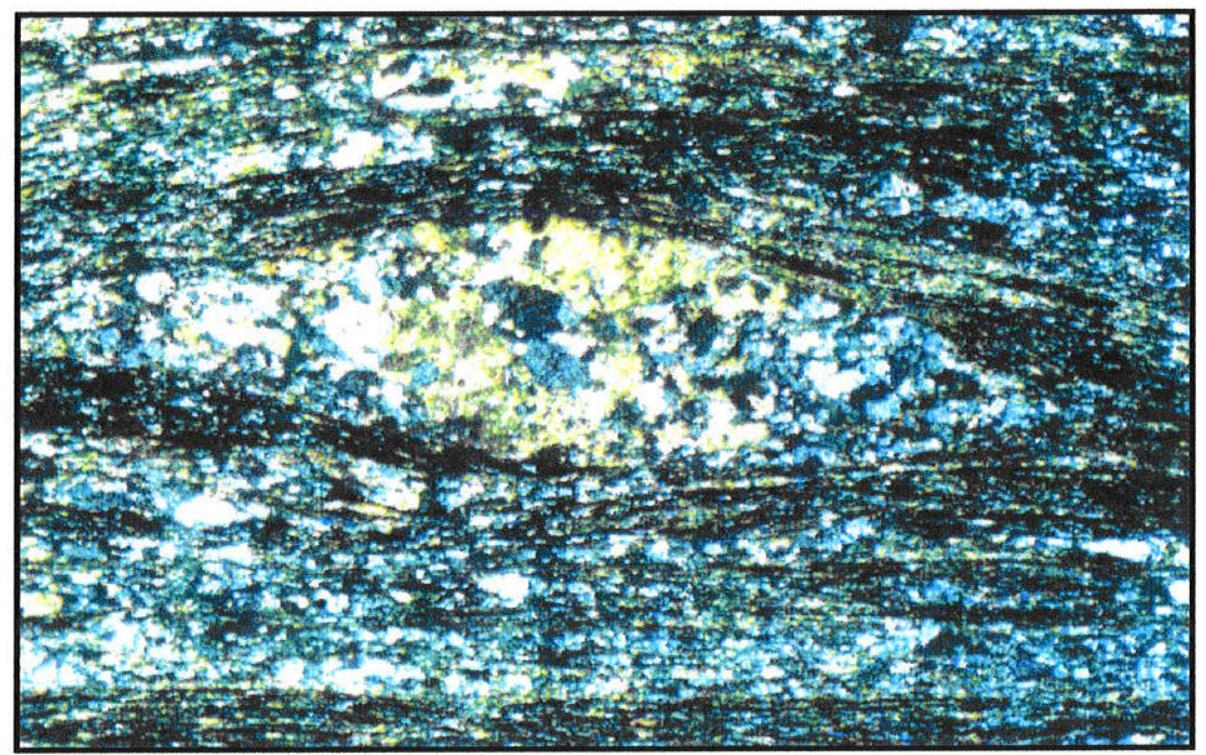

Fotomicrografia 1a : Amostra SB-02, lâmina delgada SB-02, largura da foto $2,8 \mathrm{~mm}$, luz transmitida, polarizadores cruzados. Bandamento milimétrico entre bandas quartzo-carbonáticas $\mathrm{e}$ bandas compostas por clorita e sericita onde concentram-se opacos estirados paralelamente ao bandamento. Níveis quartzo carbonáticos boudinados.

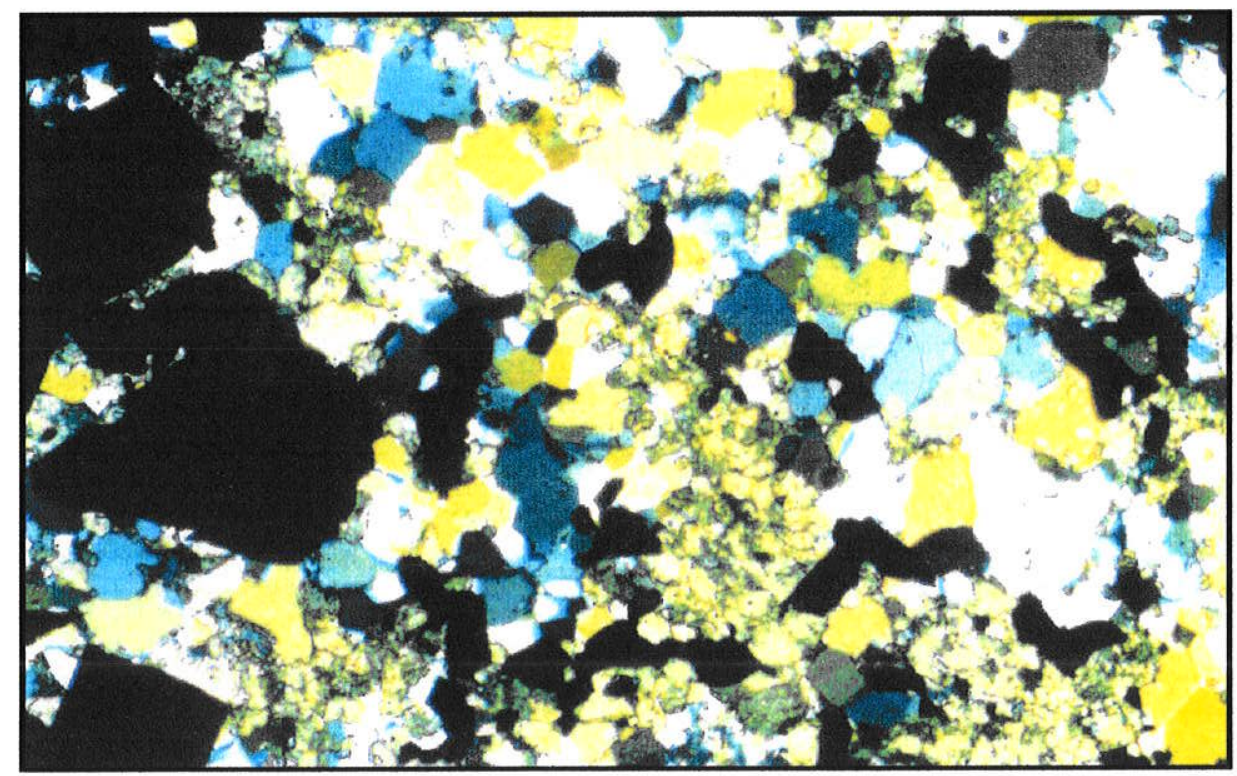

Fotomicrografia 1b: Amostrra SB-05, lâmina delgada SB-05-2, largura da foto 2,8 mm, luz transmitida, polarizadores cruzados. Bandamento quartzo-carbonático com presença de opacos intersticiais e como cristais subedrais a euedrais. 


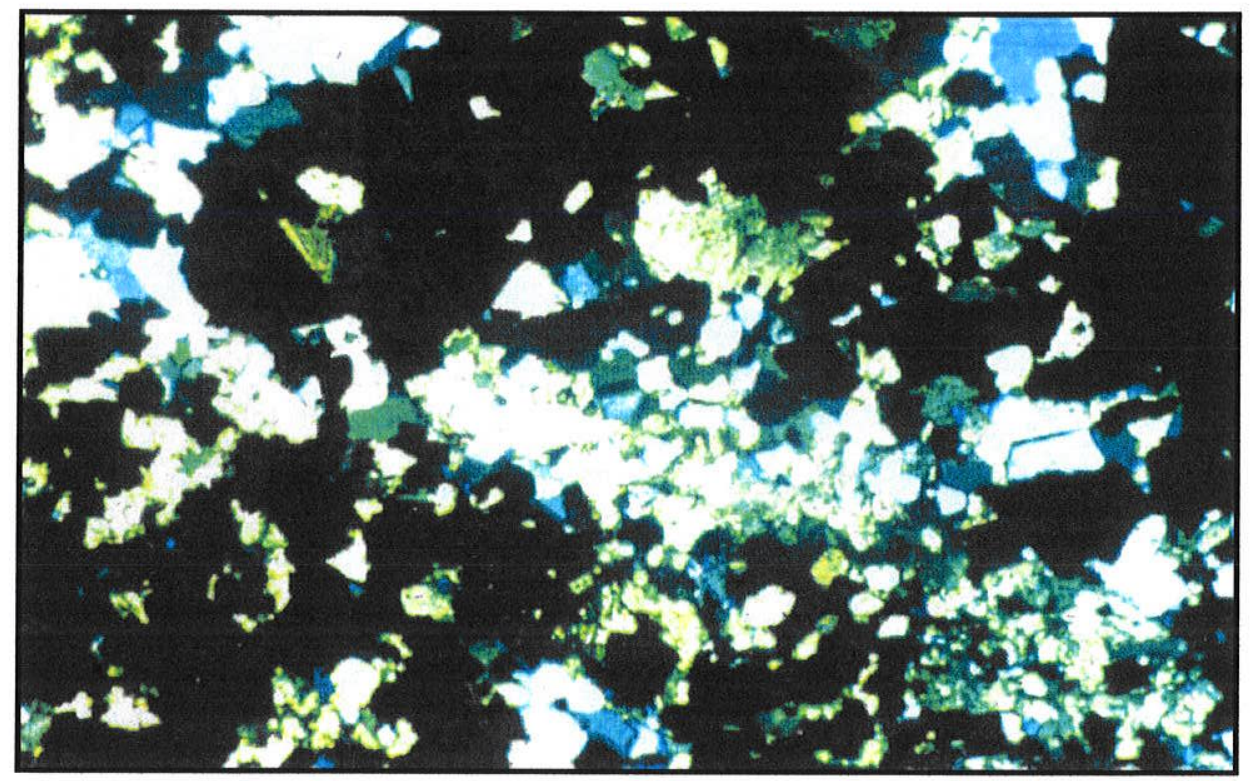

Fotomicrografia 1c: Amostra SB-09, lâmina delgada SB-09-2, largura da foto 2,8 mm., luz transmitida, polarizadores cruzados. Aspecto geral do bandamento quartzo-carbonático com opacos apresentando granulometria variável.

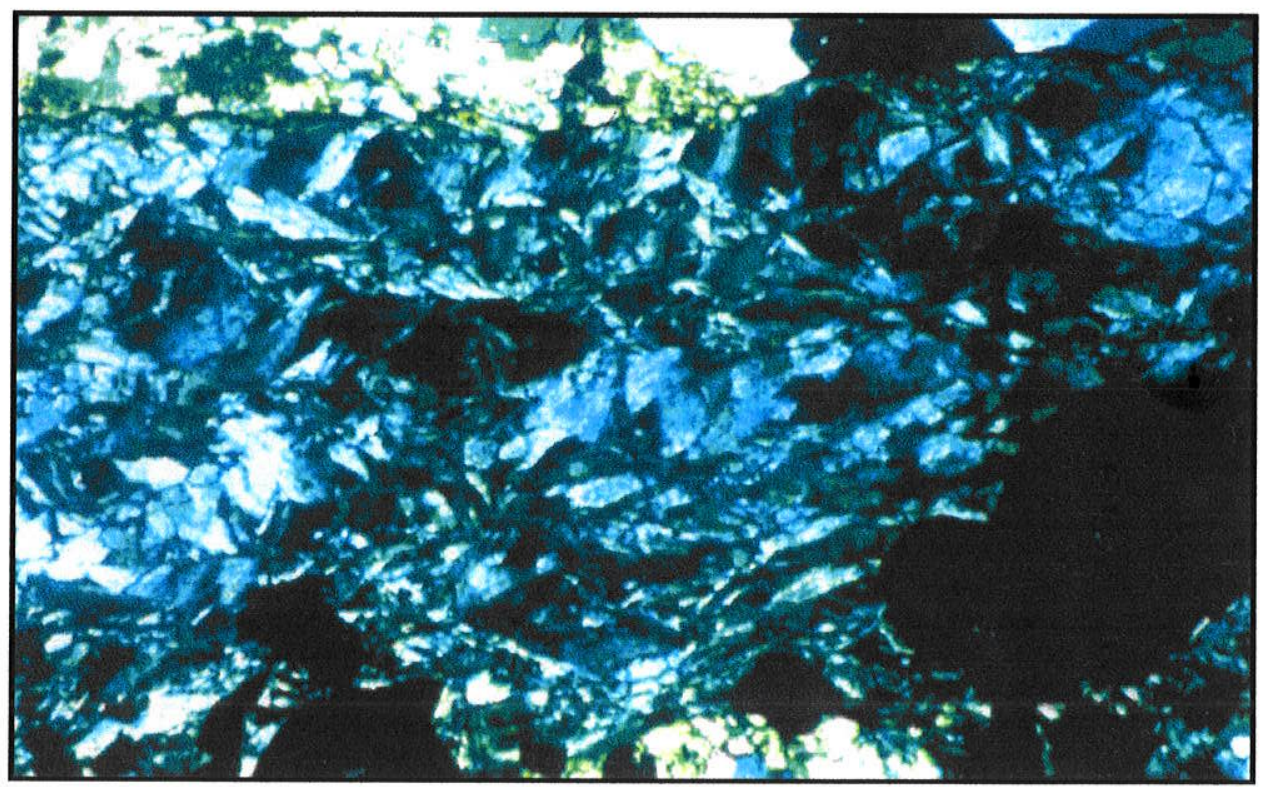

Fotomicrografia 1d: Amostra SB-09, lâmina delgada SB-09-1, largura da foto 2,8 mm., luz transmitida, polarizadores cruzados. Veio clorítico em contato brusco com o bandamento quartzocarbonático. 


\subsection{Horizontes mineralizados}

\subsubsection{Minerais de Ganga}

As características petrográficas das zonas mineralizadas são sempre semelhantes, independentemente do horizonte e de sua posição topográfica na mina.

A mineralogia é composta por quartzo, carbonatos, clorita e sericita; rutilo e plagioclásio (albita) são raros. Estes minerais compõem leitos que se alternam formando o bandamento, distinguindo-se as seguintes associações principais

- Bandas carbonáticas de textura granoblástica, granulometria variável $(<0,02 \mathrm{~mm}$ a $0,8 \mathrm{~mm}) \mathrm{com}$ clorita e quartzo subordinados.

- Bandas quartzo-carbonáticas de espessura variável $(0,1 \mathrm{~mm}$ a $3,5 \mathrm{~mm})$ e textura granoblástica. Os grãos de quartzo e carbonato variam de $(<0,002 \mathrm{~mm}$ a $0,8 \mathrm{~mm})$. Clorita e sericita associam-se a estes leitos intersticialmente (Fotomicrografias $1 \mathrm{~b}$ e $1 \mathrm{c}$ ).

- Bandas quartzosas apresentam espessuras variáveis $(0,1 \mathrm{~mm}$ a $9,0 \mathrm{~mm})$, textura poligonal e formas regulares a irregulares. A granulometria do quartzo é variável $(<0,02$ a $1,5 \mathrm{~mm})$ com cristais apresentando ou não extinção ondulante. Nestas bandas ocorre associado carbonato com granulometria variável $(<0,002$ a $0,9 \mathrm{~mm})$, em texturas variando de intersticial disseminada fina até como bolsões monominerálicos com cristais euedrais a subedrais de até $1,5 \mathrm{~mm}$.

- Bandas cloríticas com sericita associada de espessura variáveil $(0,1 \mathrm{~mm}$ a $2,0 \mathrm{~mm})$, textura lepidoblástica a grano-lepidoblástica (Fotomicrografia 1d) de forte orientação paralela ao bandamento e granulação fina a muito fina $(<0,02 \mathrm{~mm}$ a $0,1 \mathrm{~mm})$. As bandas compostas por clorita e sericita apresentam-se mais estiradas paralelas a alternância composicional e amoldando-se as bandas quartzo-carbonáticas disruptas.

\subsubsection{Petrografia dos minerais opacos}

As características petrográficas das zonas sulfetadas auríferas do depósito de São Bento, também são semelhantes entre siindependentemente do horizonte mineralizado e de sua posição topográfica na mina.

Os principais minerais opacos são, em ordem de abundância decrescente: pirrotita, arsenopirita, pirita, magnetita, calcopirita e esfalerita. Subordinadamente ocorrem ainda galena e bornita secundárias. A galena em cavidades de carbonatos lixiviados e a bornita como produto de alteração da calcopirita. Estes minerais não serão mais detalhados. As descrições são resumidas no Anexo 3 , Tabela 4. 


\section{Pirrotita}

Apresenta-se truncando as estruturas dos minerais de ganga, ocorrendo como massas xenomórficas com granulometria variável, com inclusões de outros sulfetos e ouro (Fotomicrografias $2 b$ e $2 c$ ). Ocorre também orientada e deformada concordante com o bandamento/ foliação da formação ferrífera (Fotomicrografia $2 \mathrm{~d}$ ).

suas formas de ocorrência mais raras são como inclusões finas principalmente na arsenopirita, pirita esfalerita e preenchendo fraturas tardias.

\section{Arsenopirita}

Ocorre principalmentecomo cristais euédricos a subédricos, losangulares (Fotomicrografia 3a) e prismáticos. Cristais anedrais (Fotomicrografia 3b) são mais raros. Apresentam-se sob duas formas texturais principais: Cristais com inclusões abundantes de outros sulfetos (pirita, pirrotita, calcopirita e esfalerita), minerais de ganga e ouro, e cristais limpos, com inclusões raras ou sem inclusões, ou em pequena quantidade (Fotomicrografia $3 \mathrm{c}$ ).

Podem ser observados cristais "mistos", com nítida zonação, apresentando núcleos definidos com inúmeras inclusões, bordeados por zonas de sobrecrescimento sem inclusões, frequentemente idiomórficas. A arsenopirita ocorre ainda como inclusões diminutas em piritas e pirrotitas.

\section{Pirita}

Ocorre principalmente em cristais subedrais a euedrais cúbicos, e como ciminutas inclusões principalmente na arsenopirita.

De forma similar à arsenopirita, os cristais de pirita apresentam-se com (Fotomicrografias $3 \mathrm{~d}$ e 4a) ou sem inclusões de outros sulfetos, ganga e ouro, assim como em cristais com núcleos apresentando inclusões e bordas sem inclusões (Fotomicrografia 4b).

\section{Magnetita}

É o mineral principal e típico dos BIF de fácies óxido, ocorrendo em cristais euedrais e subedrais formando camadas. Apresenta-se ainda inclusa na pirrotita e arsenopirita e, também englobando-as. 


\section{Calcopirita}

Ocorre de forma subordinada no minério, como massas anedrais associada principalmente à pirrotita e como inclusões nos principais sulfetos descritos. É comum, também, preenchendo fraturas em outros sulfetos.

\section{Esfalerita}

Ocorre, subordinada, em todas as seções descritas, como pequenas concentrações e em cristais anedrais, associados principalmente à pirrotita, assim como em diminutas inclusões nos sulfetos principais.

\section{Ouro}

Ocorre associado aos sulfetos, principalmente à pirrotita, arsenopirita e pirita. Seus cristais são, em geral, anedrais e irregulares. Suas formas de ocorrência são variadas: como microinclusões (grãos $\leq$ $5 \mu \mathrm{m}-\leq 10 \mu \mathrm{m}$ ) na arsenopirita e pirita, (Fotomicrografia 4a); como inclusões maiores na pirrotita (grãos $\geq 20 \mu \mathrm{m}-250 \mu \mathrm{m}$ ) (Fotomicrografia $2 \mathrm{~b}$ ), na interface ou em contato (Fotomicrografia 3c) com os três principais sulfetos descritos anteriormente (grãos $\geq 10 \mu \mathrm{m}-250 \mu \mathrm{m}$ ) e raramente como ouro livre na interface dos minerais de ganga. $\mathrm{O}$ ouro em microinclusões (ouro refratário) perfaz $\geq 85 \%$ do total contido no minério.

\subsection{Membro Ferrífero do Topo}

Apresenta-se como uma unidade de BIF bastante homogêneas, sem maiores variações faciológicas. $\mathrm{O}$ bandamento marcante alterna bandas compostas por quartzo-magnetita, quartzo-carbonato e quartzo-clorita-estilpnomelana (Fotomicrografia 2a), representando, respectivamente fácies óxido, carbonato e silicato.

\subsection{Formação Carrapato}

As rochas pertencentes a esta unidade são semelhantes às que ocorrem na Formação Grafitosa Basal. São clorita xistos grafitosos, sericita xistos e sericita-clorita xistos variavelmente carbonáticos e/ou quartzosos. Como minerais mais raros ocorrem pirita e rutilo. 


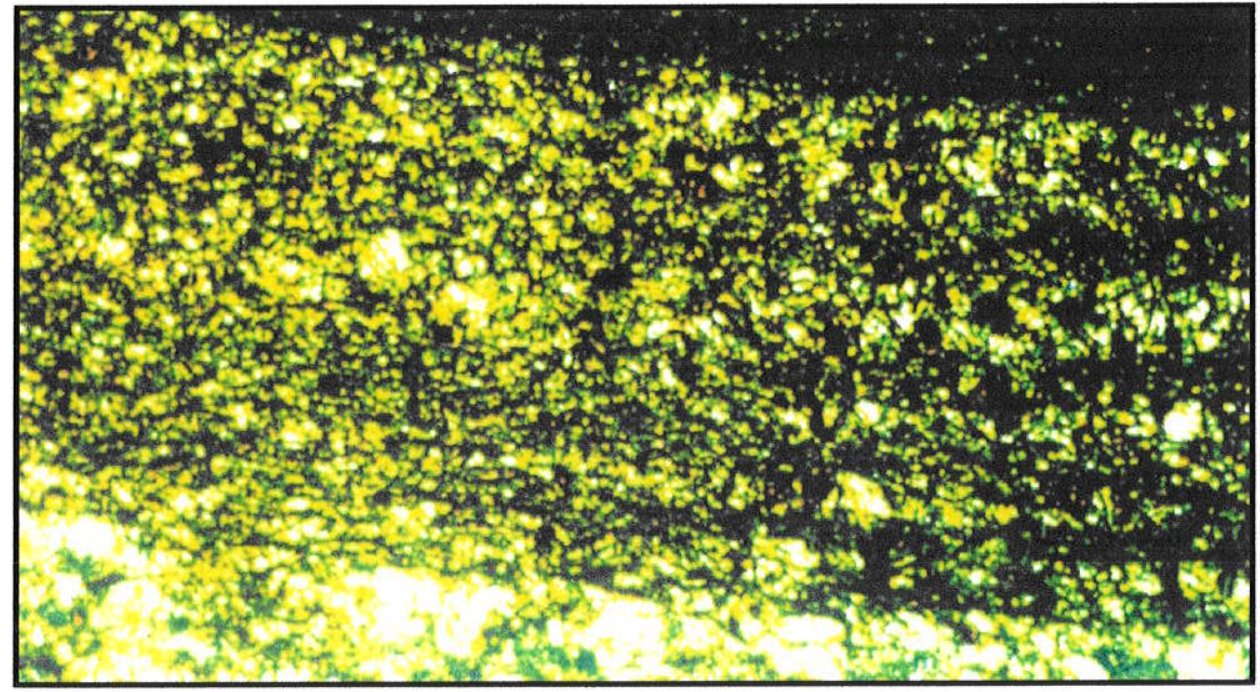

Fotomicrografia 2a: Amostra L-64, lâminda delgada L-64, largura da foto 2,8 mm., luz transmitida, polarizadores cruzados. Veio composto por estilpnomelano e clorita, apresentando-se paralelo ao bandamento.

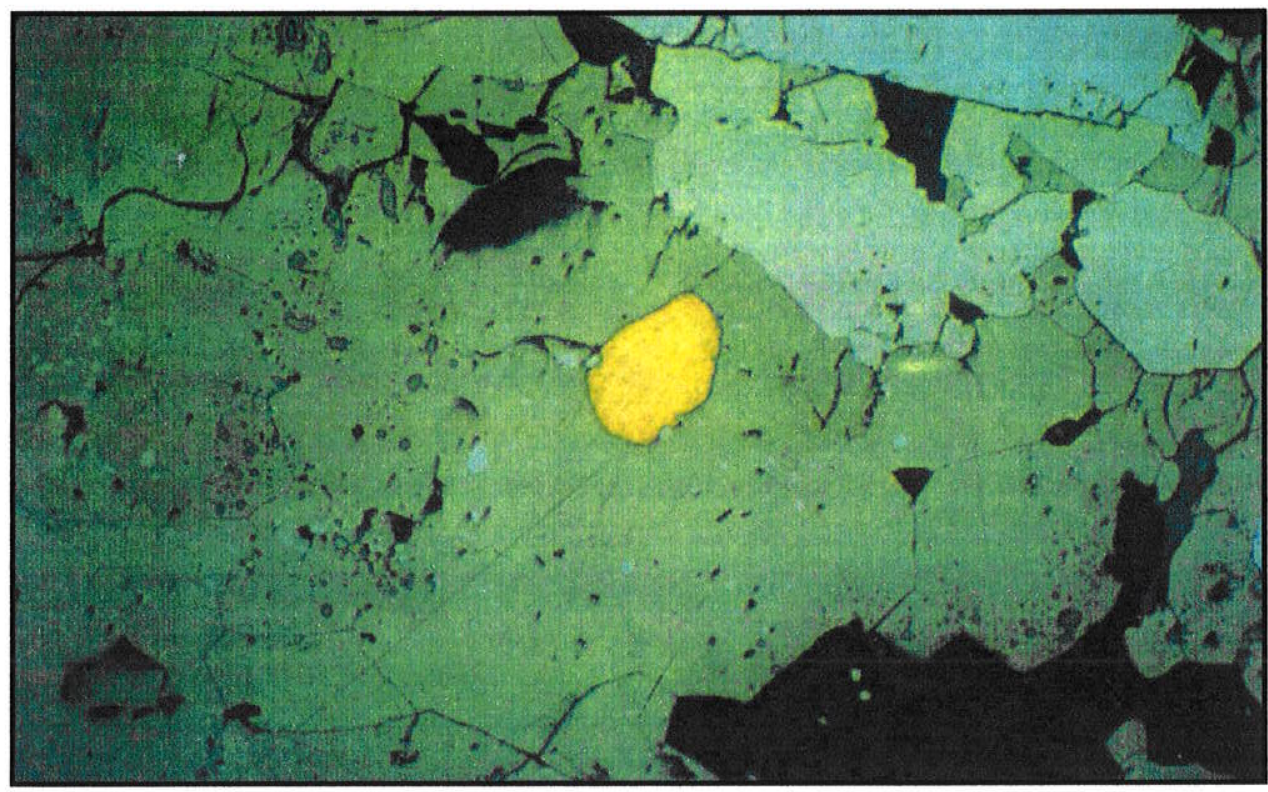

Fotomicrografia 2b: Amostrta SB-09, seção polida SB-09-2, largura da foto 0,7 mm., luz refletida, polarizadores paralelos. Ouro incluso em pirrotita. 


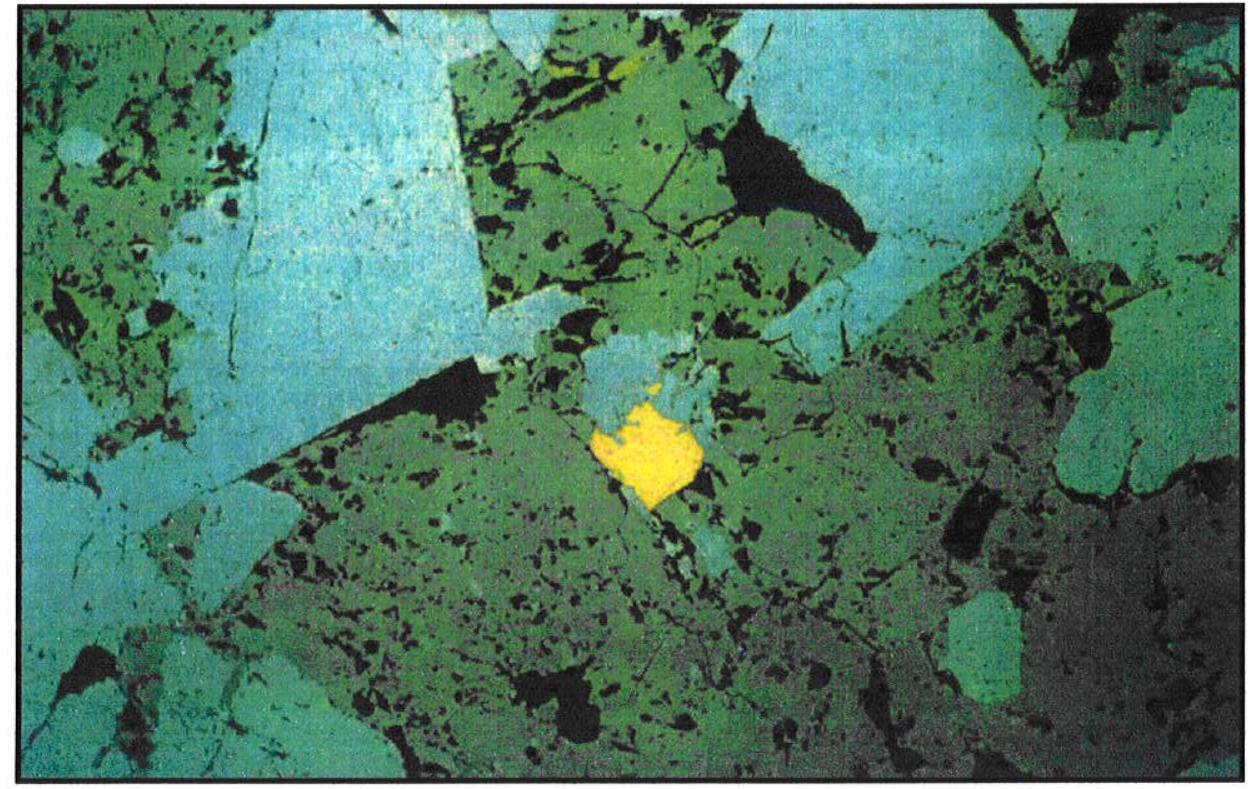

Fotomicrografia 2c: Amostra SB-15a, seção polida SB-15a-1, largura da foto 1,4 mm., luz refletida, polarizadores paralelos. Ouro incluso em pirrotita, em contato com arsenopirita.

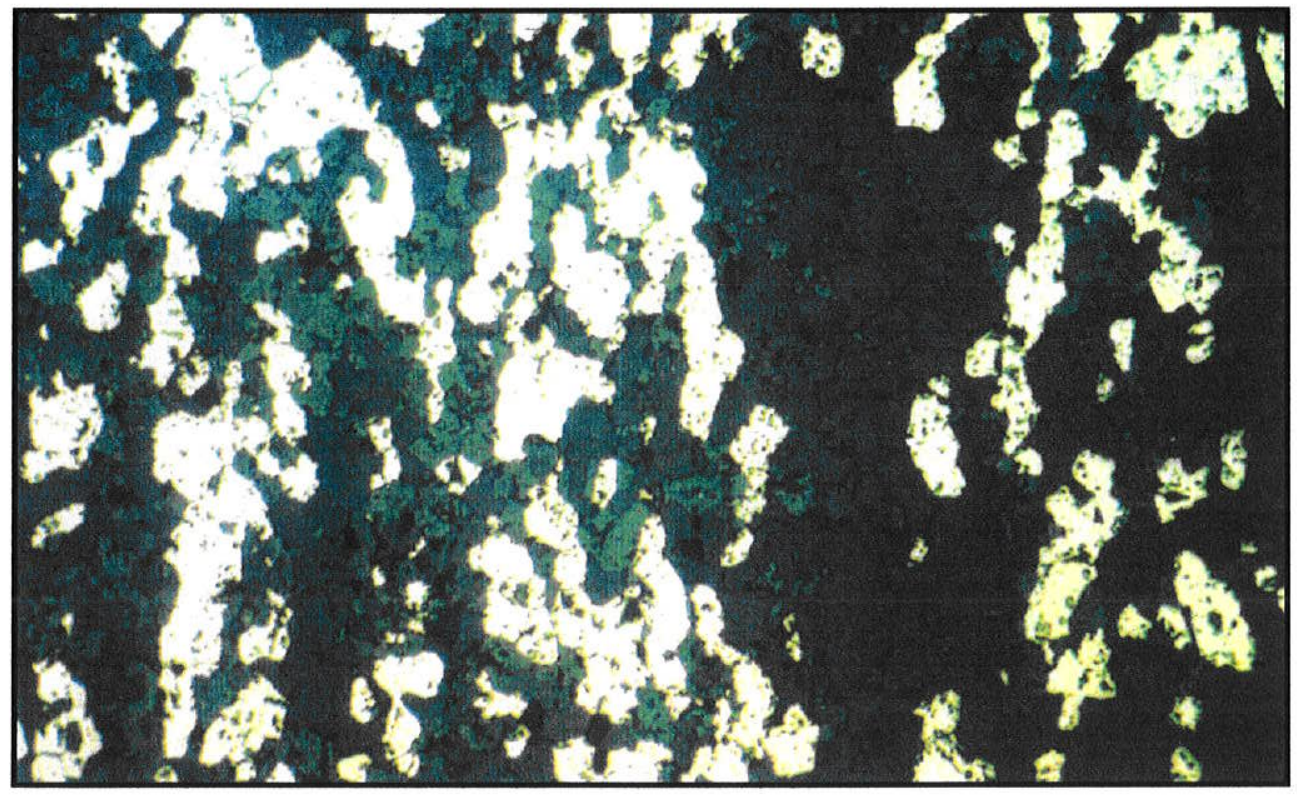

Fotomicrografia 2d: Amostra SB-09, seção polida SB-09-1, largura da foto 2,8 mm., luz refletida, polarizadores paralelos. Pirrotita xenomórfica estirada paralela à foliação. 


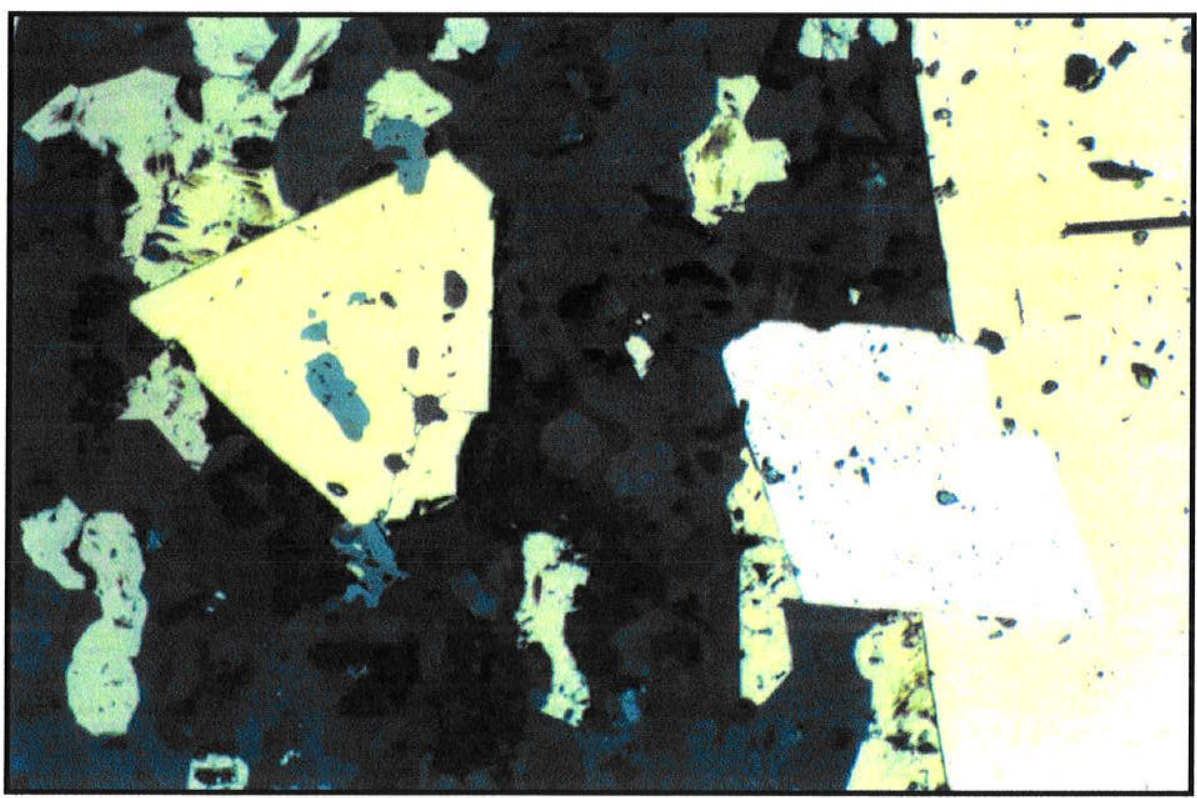

Fotomicrografia 3a: Amostrra SB-09, lâminda delgada polida SB-09-1, largura da foto 0,7 mm., luz refletida, polarizadores paralelos. Seção rômbica de arsenopirita em contato com idioblasto de pirita. Pirita subedral com inclusões de magnetita e esfalerita, cinza médio a escuro respectivamente no centro esquerdo da foto.

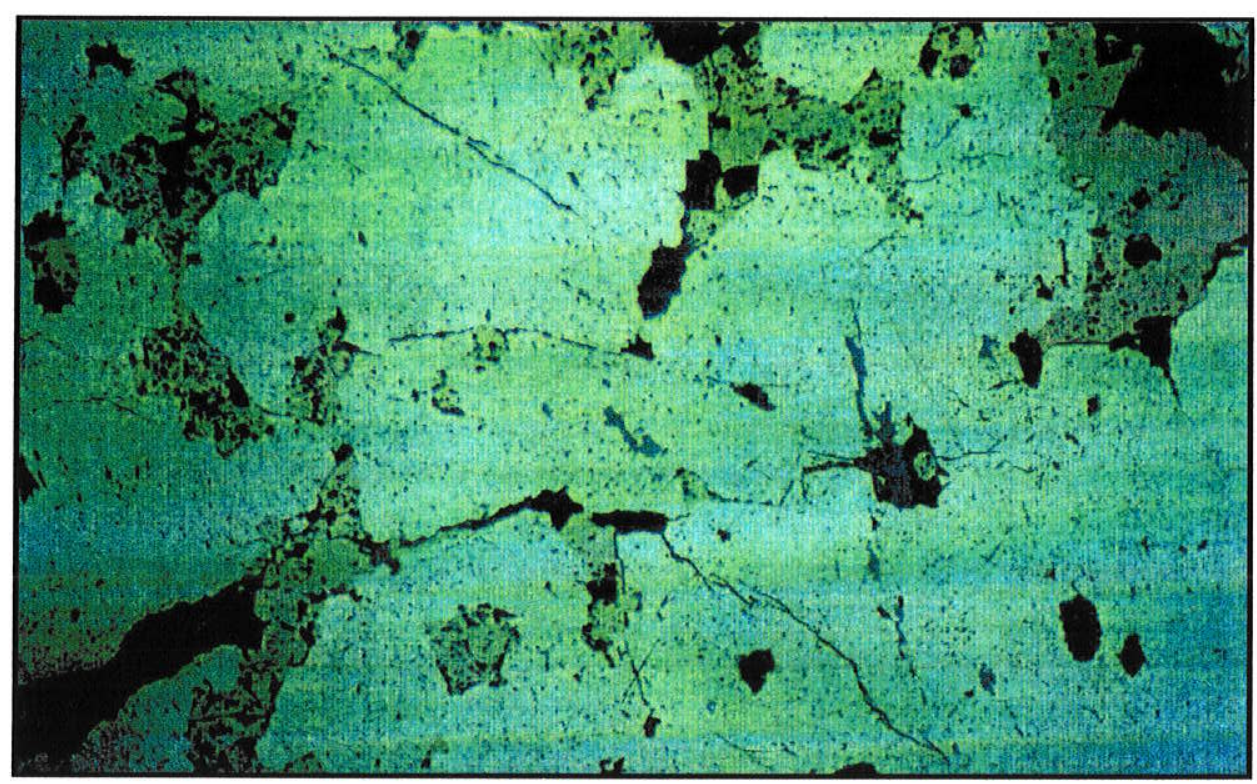

Fotomicrografia 3b: Amostra SB-09, seção polida SB-09-1, largura da foto 1,4 mm., luz refletida, polarizadores paralelos. Intercrescimento de pirrotita (mais escura) e arsenopirita. Cristais de magnetita tabular ocorrem estirados como inclusões na arsenopirita. 


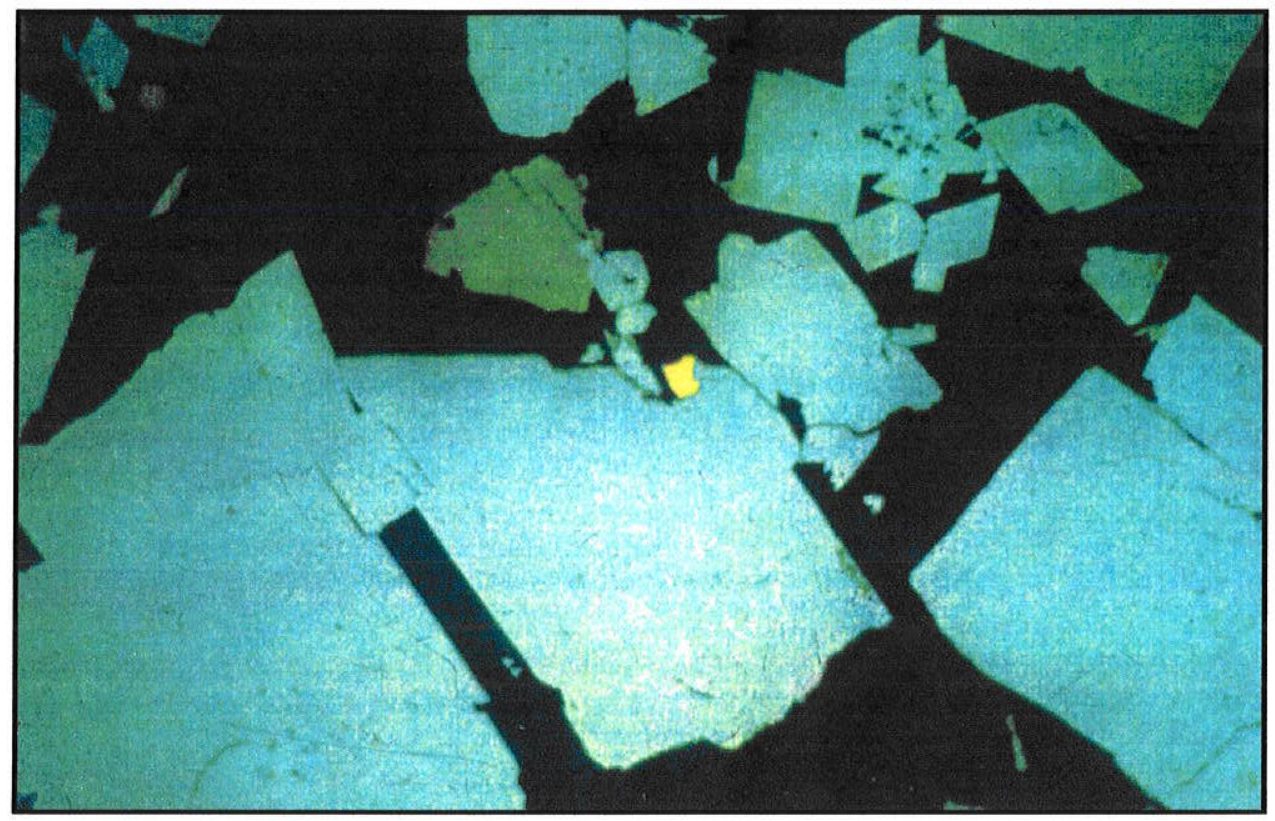

Fotomicrografia 3 c: Amostrra SB-15, seção polida SB-15C-2, largura da foto 1,4 mm., luz refletida, polarizadores paralelos. Ouro livre em contato com arsenopirita idioblástica sem inclusões.

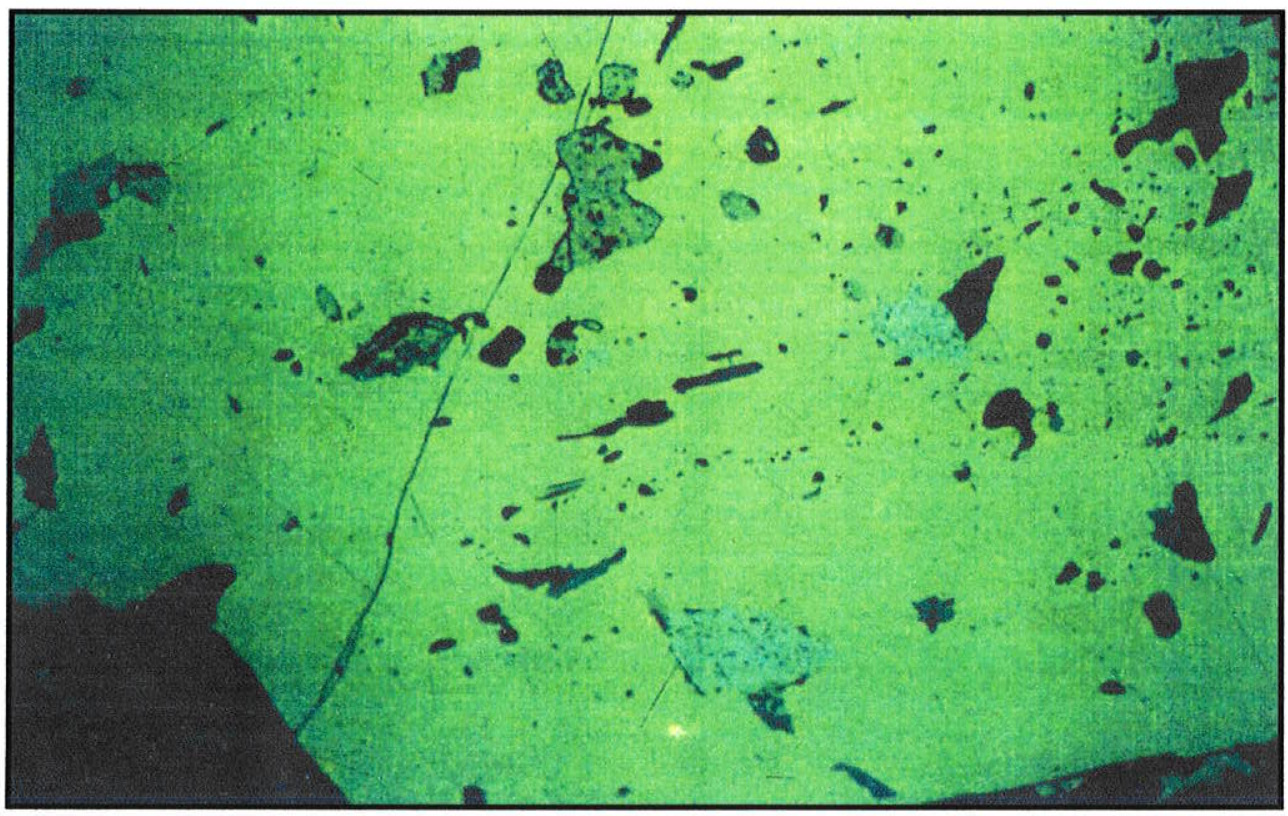

Fotomicrografia 3d: Amostra SB-09, seção polida SB-09-1, largura da foto 1,4 mm., luz refletida, polarizadores paralelos. Inclusões de pirrotita e arsenopirita em pirita idioblástica. 


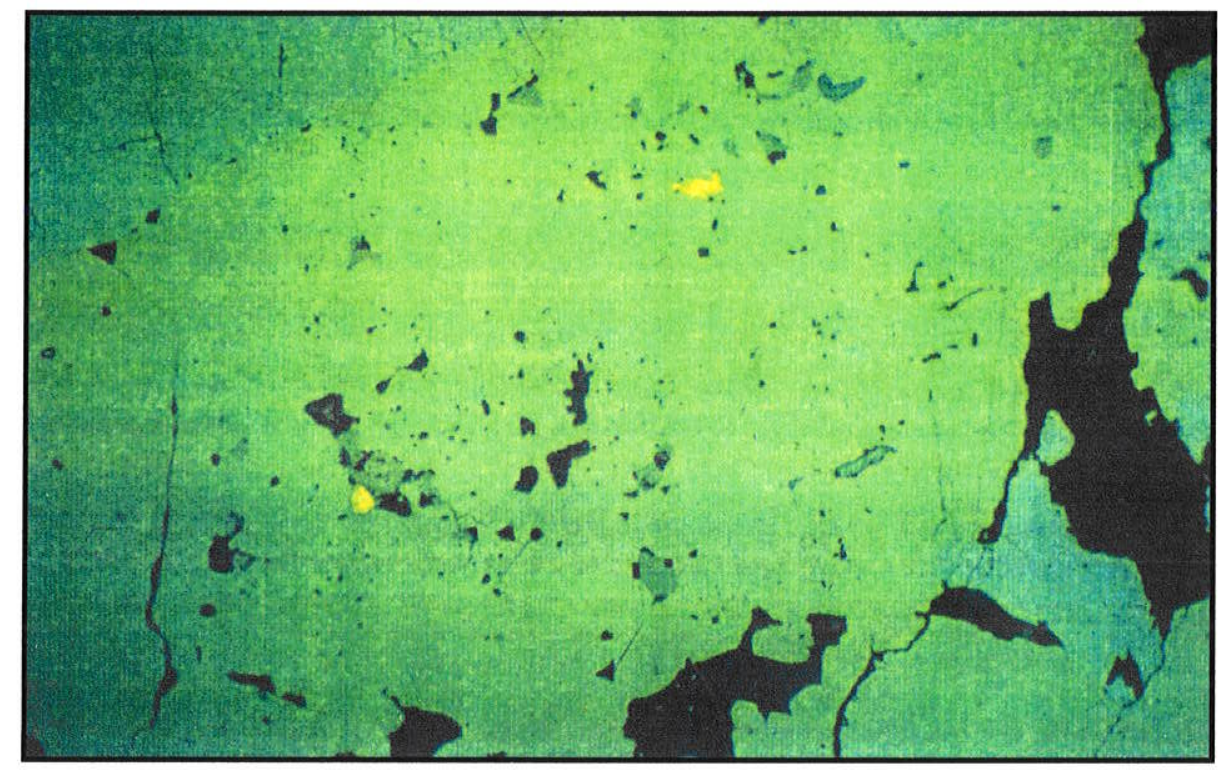

Fotomicrografia 4a: Amostra SB-10, seção polida SB-10-1, largura da foto 0,7 mm., luz refletida, polarizadores paralelos. Inclusões de ouro em pirita rica em inclusões (ganga e pirrotita).

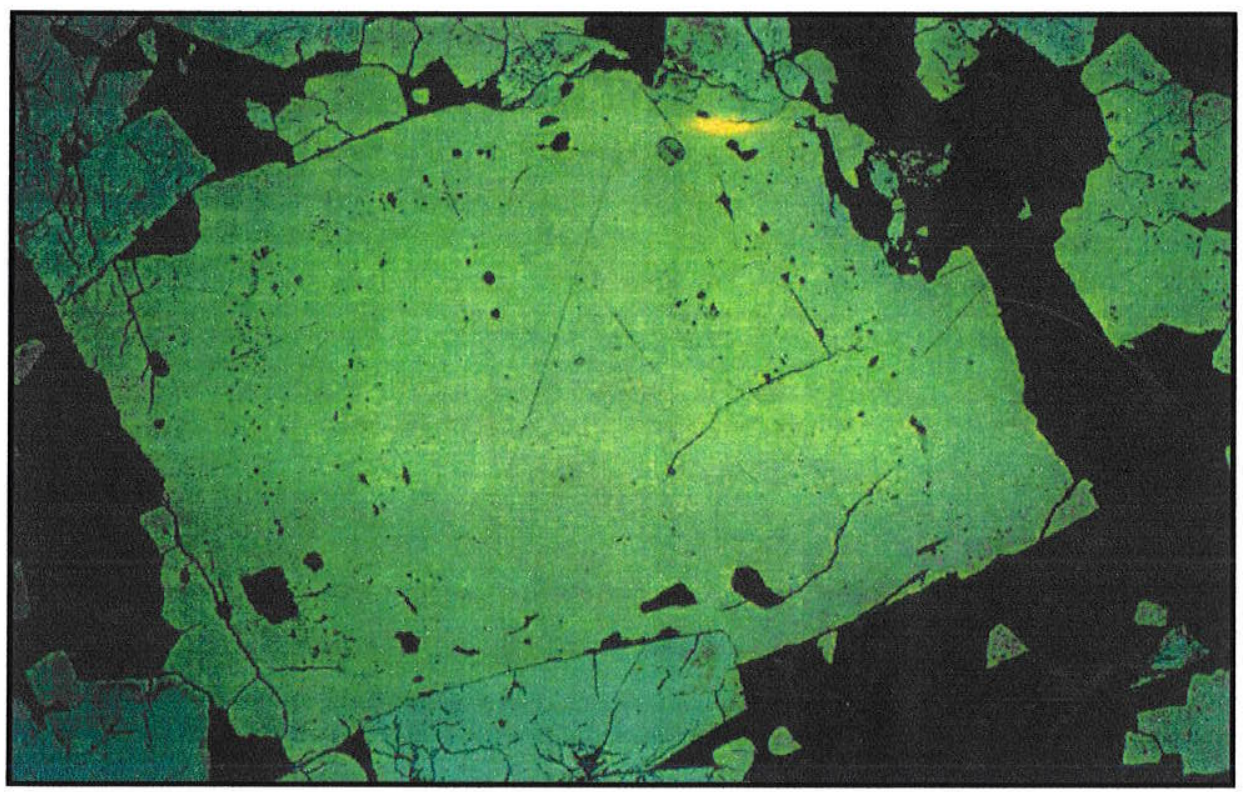

Fotomicrografia 4b: Amostra SB-10, seção polida SB-10-2, largura da foto 2,8 mm., luz refletida polarizadores paralelos. Diminutas inclusões de ouro e pirrotita em pirita idioblástica. 


\subsection{Discussão}

Diversos processos e mecanismos geológicos superimpostos contribuiram para originar as texturas; observadas, devido a este fato, interpretações acerca da gênese do minério aurífero da Mina São Bento, com base apenas nas descrições petrográficas, são arriscadas. Desta forma, serão feitas observações descritivas considerando de forma agrupada as principais características detalhadas individualmente.

Todos os minerais de minério, sulfetos, óxidos e ouro ocorrem em mais de uma, até quatro ou mesmo cinco gerações texturais e genéticas distintas. Existem claras evidências de deformação, (heterogênea para os sulfetos principais), dúctil, com a mobilização e deformação principalmente da pirrotita, que ocorre como massas xenomórficas, alongadas e estiradas. Diferentemente, a pirita e a arsenopirita se comportam, frente à mesma deformação, de forma mais competente ocorrendo cristais fraturados e/ou quebrados de deformação rúptil, bem evidenciada quando estes são envolvidos por massas de pirrotita de deformação dúctil. $\mathrm{O}$ ouro associado à pirrotita, mais provavelmente, foi remobilizado junto com ela. São observados cristais de arsenopirita e pirita com sobrecrescimento em cristais pré existentes, contendo inclusões de outros sulfetos, ganga e ouro, assim como são observados, também cristais euedrais e subedrais com poucas ou sem inclusões. Tais feições relacionam-se a processos metamórficos (Craig e Vokes, 1993).

Os minerais de ganga principais (quartzo e carbonato) apresentam extinção ondulante, textura em mosaico e junções tríplices a $120^{\circ}$, características estas, resultantes de deformação e recristalização. 


\section{Análises geoquímicas multielementares}

Nos estudos geoquímicos multielementares foram incluídas rochas encaixantes da mineralização, corpos de minério e horizontes estéreis intercalados nos corpos de minério e outros separando os horizontes mineralizados.

As análises por fluorescência de raios X (FRX) foram realizadas no Instituto de Mineralogia Aplicada e Geoquímica da Universidade Técnica de Munique, Alemanha englobando um total de 14 amostras. Os dados são apresentados na Tabela 5.

Análises por ICP-MS (Espectrometria de massa com fonte de plasma indutivamente acoplado) para ETR comtemplaram 20 amostras (Tabela 6) e foram realizadas nos laboratórios do Geoforschungszentrum (GFZ) Potsdam, Alemanha.

Análises por Fire Assay (análise quantitativa para Au e metais nobres em geral, sendo o metal separado por fusão/copelação em meio redutor, dissolvido em água régia e determinado por Absorção Atômica) de 16 amostras englobando os quatro horizontes mineralizados do Nível 15, foram relizadas no laboratório de análises químicas do Departamento de Metalurgia da São Bento Mineração e são apresentadas na Tabela 7.

A composição média dos elementos maiores (Tabela 5) para a formação ferrífera de São Bento está representada na Figura 5. As litologias e a localização das amostras estão listadas na Tabela 2 do Anexo 3.

O comportamento geoquímico dos elementos está diretamente associado à composição mineralógica das rochas. Entretanto, comparando-se os dados obtidos para as diferentes fácies de BIF, observa-se que não existem diferenças significativas entre os óxidos maiores analisados (Figuras 6 a 9) e, taõ pouco, em relação à composição média global (Figura 5).

Variações quanto aos teores de $\mathrm{Fe}_{2} \mathrm{O}_{3}$ e $\mathrm{SiO}_{2}$ (16.60-54.20 e 5.81-71.4 wt.\%, respectivamente) refletem diferenças na proporção de quartzo e de minerais de Fe nas amostras.

Diferenças para elementos maiores como o $\mathrm{Mn}$ e $\mathrm{Mg}$, podem depender das quantidades e composições dos carbonato (ankerita e/ou siderita) presentes.

As formações ferríferas, em particular as pertencentes à fácies silicática, contém teores mais elevados de $\mathrm{TiO}_{2}$ e principalmente $\mathrm{Al}_{2} \mathrm{O}_{3}$, que indicariam contribuições clásticas nessas formações, entretanto, também poderiam ter origens vulcânicas/vulcanoclásticas (de tufos e/ou tufitos) básicos (Dymek e Klein, 1988). 


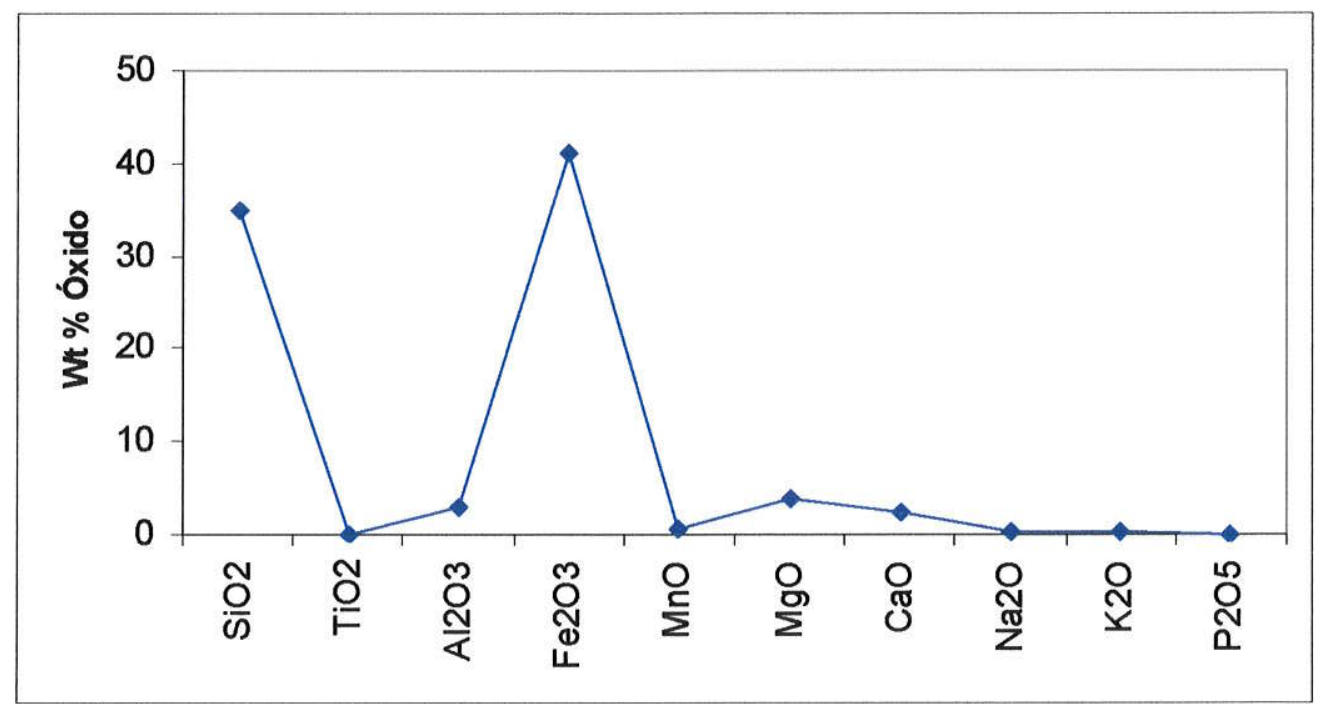

Figura 5: Composições médias dos elementos maiores da formação ferrífera São Bento.

A comparação entre as médias de alguns metais de transição ( $\mathrm{V}, \mathrm{Cr}, \mathrm{Co}$, Ni e $\mathrm{Zn})$ de amostras de formações ferríferas de São Bento e de Isua (Dymek \& Klein, 1988) mostram similaridades (Figura 10), exceto para os teores de $\mathrm{Cr}$ (40,3 e 108,0 ppm) e de $\mathrm{Zn}(109,8$ e 196,0 ppm) mais elevados para os BIF de São Bento. As concentrações de V e Co são similares, enquanto que os teores de Ni para Isua apresentam-se mais elevados. Comparando-se o gráfico de $\mathrm{V}, \mathrm{Cr}$, Co e $\mathrm{Ni}$ para os BIF e as rochas encaixantes de São Bento observa-se concentrações maiores de $\mathrm{Cr}$, Co e Ni nas encaixantes em relação aos BIF (Figura 11). 


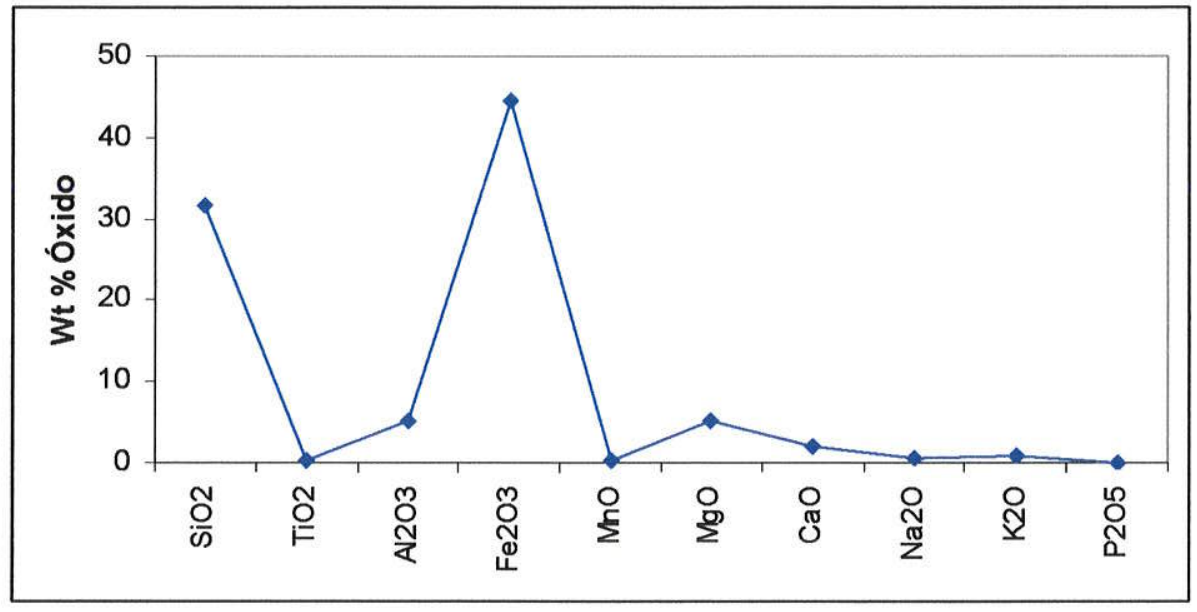

Figura 6: Composições médias dos elementos maiores de BIF fácies silicato de São Bento.

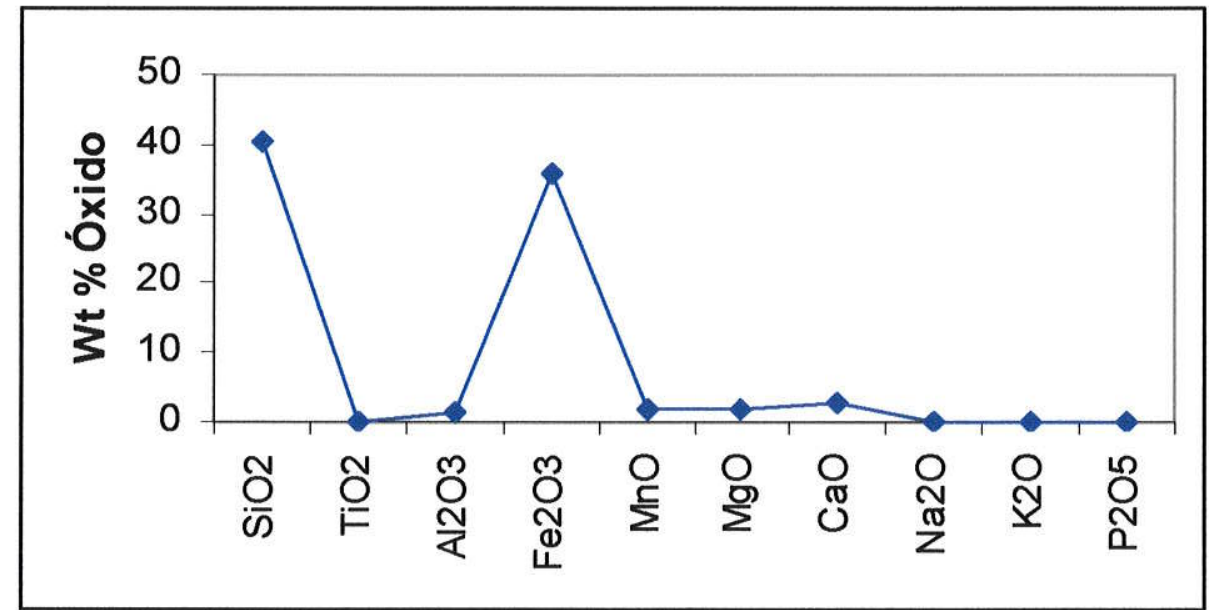

Figura 7: Composições médias dos elementos maiores de BIF fácies carbonato de São Bento. 


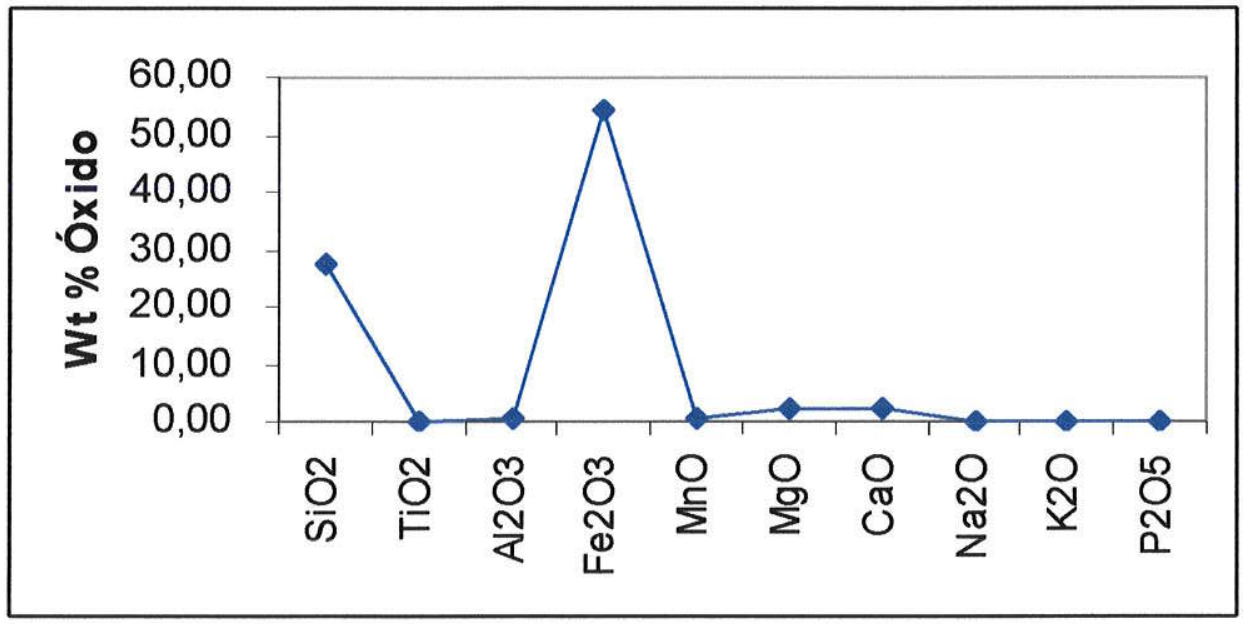

Figura 8: Composições médias dos elementos maiores de BIF fácies óxido de São Bento.

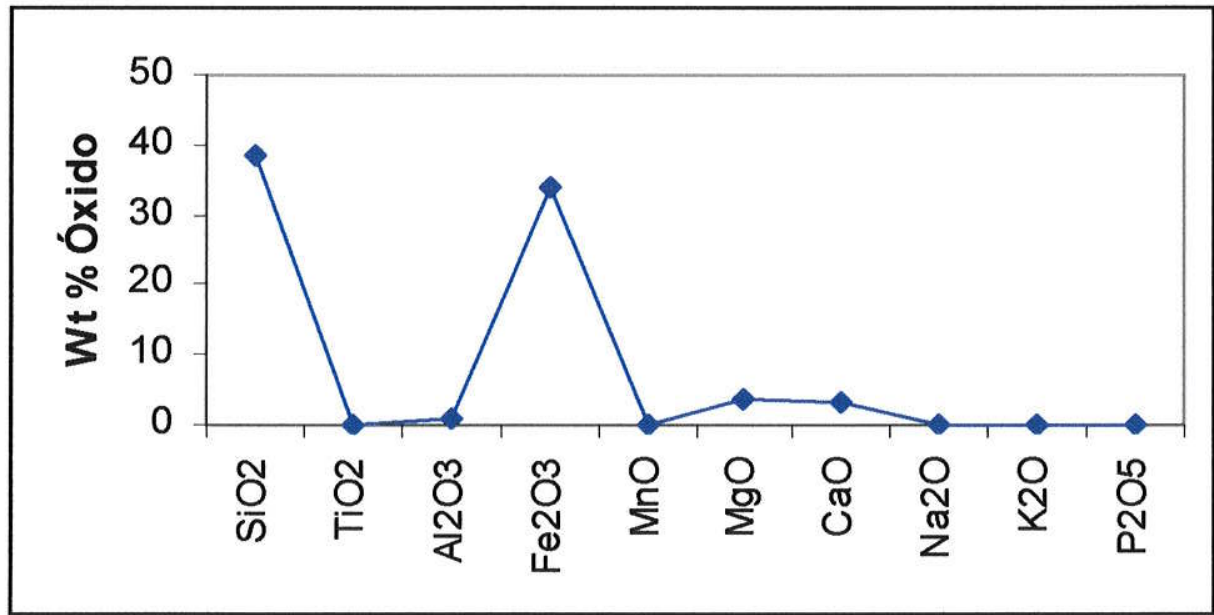

Figura 9: Composições médias dos elementos maiores de BIF fácies sulfeto de São Bento. 


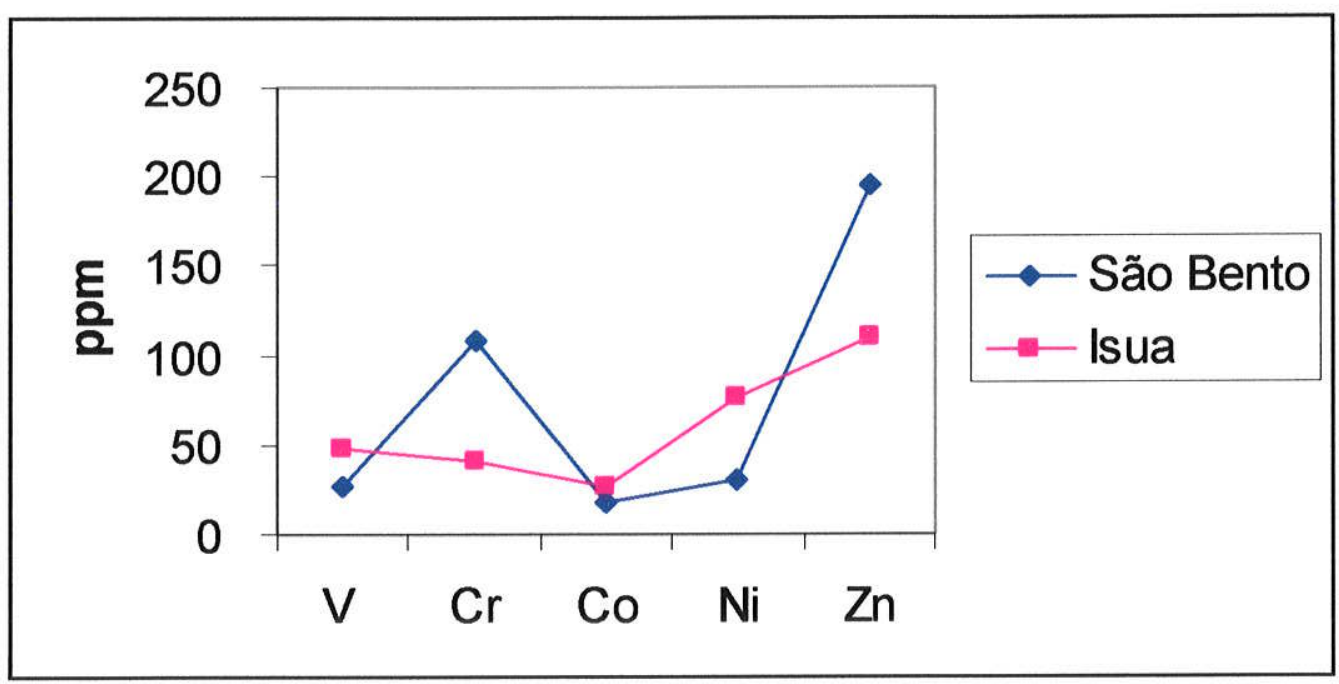

Figura 10: Comparação dos teores médios de alguns metais de transição de BIF de Isua (Dymek \& Klein, 1988) e São Bento.

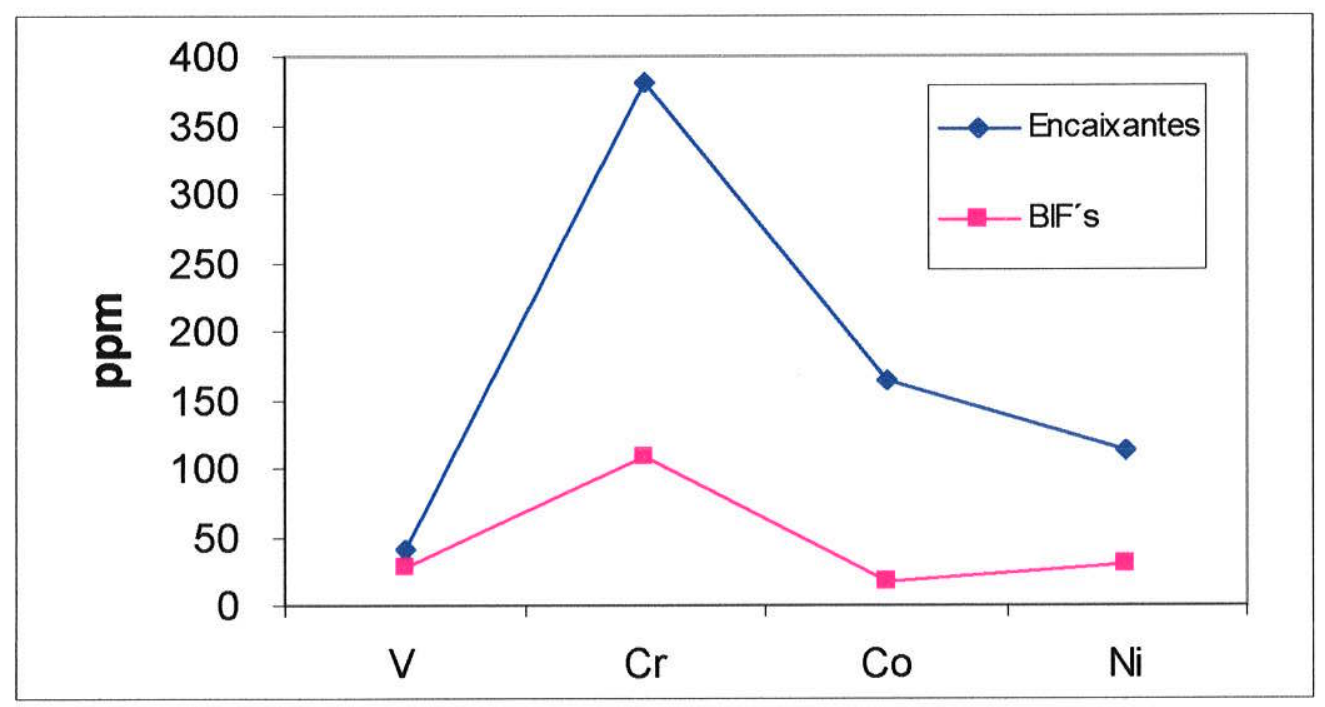

Figura 11: Comparação dos teores médios de alguns metais de transição nos BIF e nas rochas encaixantes de São Bento.

O ouro na formação ferrífera fácies sulfeto da mina São Bento ocorre, preferencialmente, associado aos sulfetos (pirita, pirrotita e arsenopirita), fato corroborado pela análise dos gráficos $\mathrm{Au} \times \mathrm{S}$ e $\mathrm{Au}$ $\mathrm{x}$ As (Figuras 12 e 13 respectivamente). Observa-se a boa correlação positiva do Au com os outros dois elementos. 


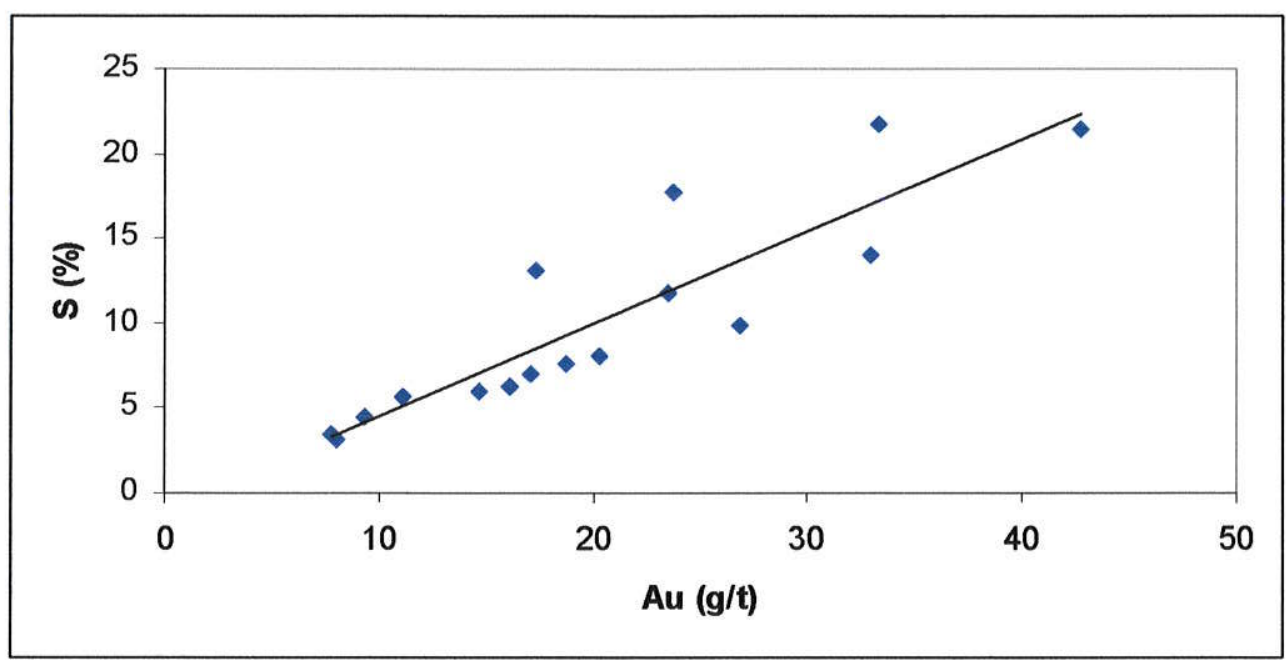

Figura 12: Correlação Au x S em BIF de fácies sulfeto de São Bento.

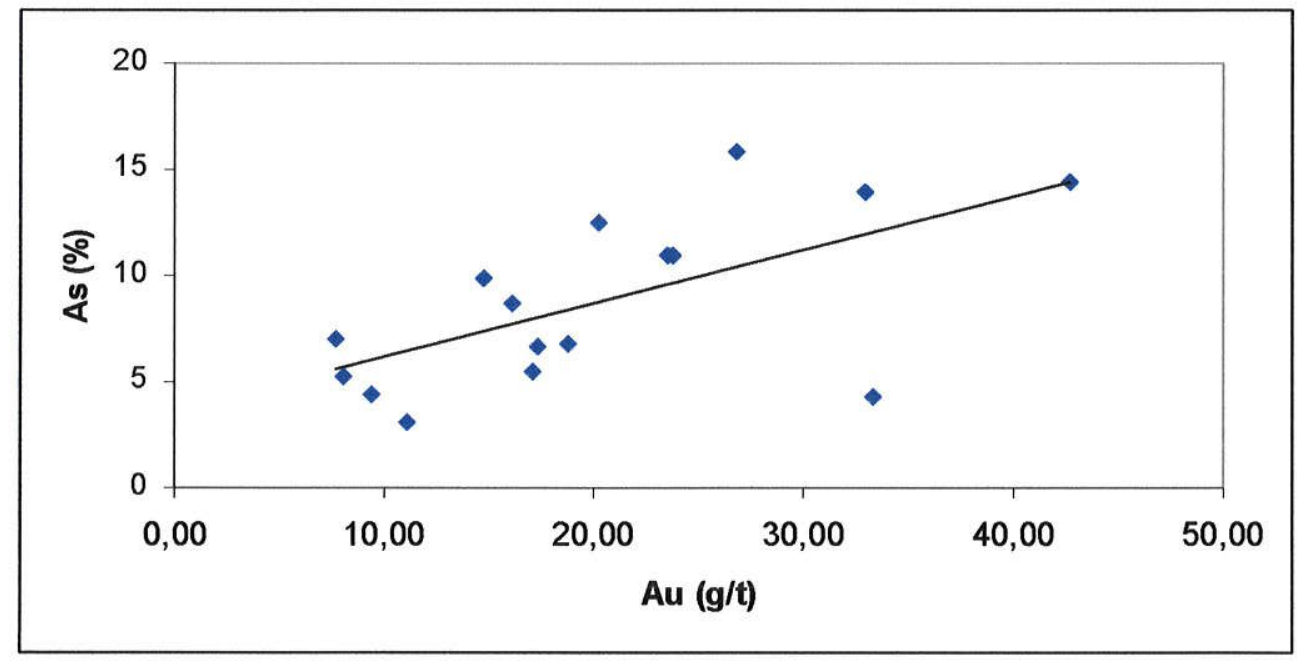

Figura 13: Correlação Au x As em BIF de fácies sulfeto de São Bento. 
As análises dos elementos terras raras (ETR) demonstram variações, entretanto, todas as fácies de BIF apresentam anomalias positivas de Eu e negativas de Ce (Figura 14). Os dados de São Bento apresentam-se semelhantes àqueles obtidos por Dymek e Klein (1988) para amostras de BIF de Isua, que interpretaram tais anomalias como indicativos da deposição dos BIF em ambiente marinho sob a ação de soluções hidrotermais/redutoras.

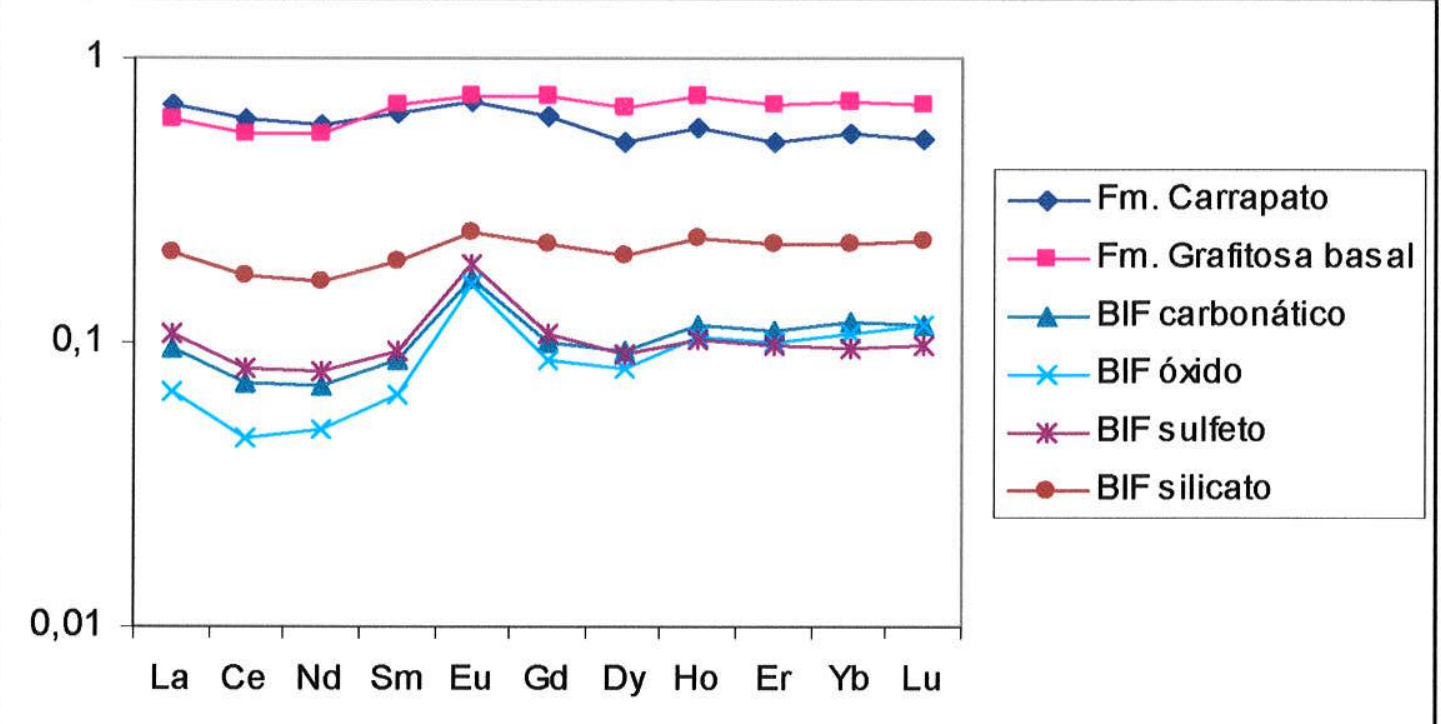

Figura 14: Padrões de teores médios dos elementos terras raras de BIF e rochas encaixantes de São Bento (normalização NASC).

Os BIF de fácies carbonato, óxido e sulfeto de São Bento apresentam grandes similaridades entre si, com teores baixos de ETR totais e fracionamento dos ETR leves. As rochas encaixantes também apresentam concentrações de ETR próximas e similares entre si, porém, sempre com teores individuais e totais de ETR mais elevados do que todos os BIF. Também apresentam padrões (com normalização NASC) mais planos e ausência de anomalia de Eu e Ce. Os BIF de fácies silicato apresentam-se intermediários entre os dois grupos (Figura 14).

Michard et al., (1983) assinalaram que soluções hidrotermais atuais são caracterizadas por baixas concentrações de ETR, fracos enriquecimentos de ETR leves e anomalias positivas de Eu.

A assinatura de ETR em sistemas hidrotermais é modificada pela mistura com a água do mar, e o fato da água do mar do Pacífico Norte próxima ao East Pacific Rise ser enriquecida em Eu comparada à água do Atlântico Norte pode representar efeitos de componentes hidrotermais (Klinkhammer et al., 1983). Por analogia, segundo Dymek e Klein, (1988) os padrões dos ETR dos 
BIF Arqueanos também sugerem sua deposição a partir de soluções que seriam misturas da água do mar e de fluídos hidrotermais.

Por fim, esses autores (Dymek e Klein, 1988) ainda descreveram para os depósitos de sulfetos hidrotermais auríferos recentes de fundo oceânico de Famous e Galápagos, leves anomalias negativas de Ce e anomalias positivas de Eu e, também, semelhanças quanto à abundância de ETR totais em comparação a BIF arqueanos. 


\section{Conclusões}

A sequência supracrustal que hospeda, na área de trabalho, a mineralização de ouro da mina São Bento é parte do greenstone belt arqueano Rio das Velhas definido como Supergrupo Rio das Velhas (Schorscher, 1978; 1979; 1992), pertencendo a sua unidade estratigráfica média, metavulcano-sedimentar máfica, denominada Grupo Nova Lima.

A sequência foi informalmente subdividida e compreende, de W para $\mathrm{E}$, rochas metassedimentares finas (xistos) da Formação Grafitosa Basal; seguem-se com contato brusco, metassedimentos químicos representados por espessos níveis de formações ferríferas com intercalações metassedimentares clásticas designados Formação Ferrífera São Bento; por fim, ocorrem novamente rochas metassedimentares clásticas finas, (similares aqueles da Formação Grafitosa Basal) compreendidos na Formação Carrapato.

A mineralização aurifera é parte da Formação Ferrífera São Bento, que se constitui num pacote de BIF mais espesso de extensão regional predominando as fácies óxido com magnetita, carbonato e silicato com teores anômalos de Au, porém muito abaixo de econômicos.

A deformação principal gerou as foliações principais, assim como as lineações de estiramento mineral. As rochas encaixantes imediatas da mineralização sofreram deformação/foliação máxima, adquirindo aspecto milonítico pelo desenvolvimento de zonas de cisalhamento diferencial (entre os BIF da mineralização e os xistos encaixantes). Nos níveis de formação ferrifera observa-se o bandamento composicional bem preservado. Deformaç̃es posteriores afetaram todas essas rochas. Ainda sob regime dúctil foi gerada crenulação e, em condições rúpteis, sistemas de falhas e fraturas, causando remobilização de sulfetos ouro pela circulação de fluídos hidrotermais tardios.

$\mathrm{O}$ metamorfismo regional principal, progressivo no sentido direcional de $\mathrm{E}$ para $\mathrm{W}$ atingiu na área da mina São Bento, condições da fácies xisto verde inferior, assinaladas pela associação quartzo+clorita+sericita e quartzo+Fe-estilpnomelana+sericitatclorita assim como pela ausência geral da biotita (Winkler, 1977).

Através da análise petrográfica, observou-se que existem mais de uma geração de todos os sulfetos e do ouro na mineralização.

A parte predominante da pirrotita que, entre todos, é de longe, o sulfeto mais dúctil foi reconformada durante a principal fase de deformação, estando estirada, paralela à foliação e, a estas concentrações de cristais deformados associam-se os grãos de ouro com granulometria mais grossa 
$(\geq 20 \mu \mathrm{m}-250 \mu \mathrm{m})$. As reações e reequilibrações metamórficas causaram a liberação e crescimento granulométrico do ouro livre e intercrescido na pirrotita.

Piritas e arsenopiritas, predominantes na mineralização apresentam bordas idiomórficas sem inclusões crescidas sobre núcleos, e em geral, partes internas irregulares desses mesmos cristais ricos em inclusões de minerais de ganga, outros sulfetos e ouro. Também ocorrem cristais euedrais a subedrais sem ou com apenas poucas inclusões representando, em sua maioria, cortes nas partes externas sem inclusões de cristais com bordas idiomórficas; em menor proporção ocorrem ainda piritas e arsenopiritas idiomórficas sem inclusões neoformadas.

As bordas idiomórficas assim como as piritas e arsenopiritas neoformadas são produtos do ápice termal do principal metamorfismo regional progressivo, conforme mostram estudos de geotermometria metamórfica desses sulfetos realizados pelo orientador (utilizando, entre outros, o geotermometro de As na arsenopirita)

O ouro incluso nos núcleos e partes internas dos cristais de pirita e arsenopirita tem granulometria muito fina $(\leq 5 \mu \mathrm{m} \sim \leq 10 \mu \mathrm{m})$, porém predomina na mineralização perfazendo cerca de $80 \%$ do teor total de Au do minério lavrado.

A assinatura geoquímica das formações ferríferas, à luz dos metais de transição e ETR enfocados neste trabalho, é virtualmente constante entre tipos pares de BIF e, em geral, muito similar entre todos os tipos de BIF aqui estudados, estando ainda em perfeita analogia com outras BIF do mundo. Não foram observadas variações desses padrões geoquímicos em relação aos teores de Au e sim, sua analogia com depósitos recentes de sulfetos auríferos de tipo smokers, de fundo oceânico.

Em relação às rochas encaixantes as diferenças geoquímicas são muito bem definidas e bruscas.

A gênese da mineralizacão tem sua origem em processos arqueanos singenéticos, exalativos, de sedimentação química com contribuições clásticas e vulcanoclásticas (tufitos) finos. Tais processos ocorreram em ambiente distal em relação a centros vulcânicos ativos do greenstone belt Rio das Velhas, pois, até o momento não foram identificadas rochas vulcânicas sinsedimentares na mina São Bento e arredores próximos. O pacote de rochas e minérios do Grupo Nove Lima da mina São Bento foi afetado por processos tectono-metamórfico-hidrotermais posteriores, gerando remobilizações e redistribuições dos sulfetos e do $\mathrm{Au}$, sem contribuições externas notáveis. Esses processos tectono-metamórficos e hidrotermais posteriores pouco afetaram o pacote mineralizado, gerando principalmente efeitos mineralógico-texturais. 


\section{Referências bibliograficas}

Abreu, A. S., Diniz, H. B., Prado, M. G. B., Santos, S. P. 1988. Mina de ouro de São Bento, Santa Bárbara, Minas Gerais. In: Schobbenhaus, C. e Coelho, C. E. S. (Editores), Principais depósitos minerais do Brasil - metais básicos não-ferrosos, ouro e alumínio, 3: 393-411.

Abreu, G. C. 1995. Geologia e Metalogênese do ouro da mina do Pari, NE do Quadrilátero Ferrifero-MG. Dissertação de Mestrado, 140 p., IG - USP.

Alkimin, F.F., Chemale jr., F. Bacellar, L. A. P., Oliveira, J. R. P. e Magalhães, P. M. 1989: Arcabouço estrutural da porção sul da Bacia do São Francisco - In: $5^{\circ} \mathrm{Simp}$. Geol. Minas Gerais, Anais, 289-293, SBG, Núcleo Minas Gerais, Bol.10, Belo Horizonte.

Almeida, F. F. M. 1976. Estruturas do Pré-Cambriano Inferior Brasileiro. - In: $29^{\circ}$ Cong. Bras. Geol., Resumos: 201-202, SBG, Ouro Preto/Belo Horizonte.

Almeida, F. F. M. 1977. O Cráton do São Francisco. Rev. Bras. Geoc., 7:349-64.

Alves, M. G. 1986. Utilização de sensoriamento remoto na obtenção de dados litoestruturais em trabalho geológico de detalhe na região NE do Quadrilátero Ferrífero (MG). - Dissertação de Mestrado, INPE (SERE), São José dos Campos.

Alves, J. V. 1995. Estudo de Inclusões Fluídas em Veios de Quartzo da Mina de Ouro de São Bento, Santa Bárbara, MG. Unpub. M.Sc. Thesis, Univ. Fed. Minas Gerais, Belo Horizonte, $99 \mathrm{p}$.

Barbosa, A. L. M. 1968. Contribuições recentes à geologia do Quadrilátero Ferrífero. Conferência proferida na Soc. Bras. de Geol. Minas Gerais em 1968. Impressão IGC-UFMG, 1985.44p.

Barbosa, O. 1935. Estudo de amostras da região aurífera de Caeté - Santa Bárbara. DNPM report, $478,40 \mathrm{pp}$.

Barbosa, O. 1939. Petrologia da região aurífera de Caeté e Santa Bárbara. DNPM/DFPM, Rio de Janeiro, Bull. 38, 153-186.

Barbosa, O. 1954: Évolution du géosynclinal Espinhaço. - In: 19th Inter. Geol. Cong., Sec. XIII, 2. part., Fascícule XIV: 17-36, Alger.

Belo de Oliveira, O. A. 1986a. As falhas de empurrão e suas implicações na estratigrafia e metalogênese do Quadrilátero Ferifero. In: Congresso Brasileiro de Geologia, Goiânia, 1986, Soc. Bras. Geol., extr. abstr. vol., 2: 1074-1087.

Chemale Jr., Rosière, C. A., Endo, I. 1994. The tectonic evolution of the Quadrilátero Ferrífero, Minas Gerais, Brazil. Precambrian Research, 25 - 24.

Craig, J. R. e Vokes, F. M. 1993. The metamorphism of pyrite and pyritic ores: an overview. Mineralogical Magazine, V. 57, pp.13-18.

Davies, H. P. K. 1993. Petrogênese e evolução crustal pré-Cambriana da região de Bateias (Quadrícula 1:25.000 NE da Folha Topográfica Catas Altas 1:50.000) Quadrilátero Ferrifero-Minas Gerais. - Diss. Mestrado, 74 p., IG-USP, São Paulo. 
Derby, O.A. 1906. The Serra do Espinhaço, Brazil. - J. Geol., 14 (5): 374-401.

Dorr, J. V. N. 1966. Stratigraphy. - Pr. IV-2-IV-5, in: Outline of the Geology of the Quadrilatero Ferrífero, Minas Gerais, Brazil, Amer. Geol. Inst., Brazil, Washington 1966.

Dorr, J. V. N; Gair, J. E. ; Pomerene, J. B.; Rynearson, G. A. 1957. Revisão da estratigrafia PréCambriana do Quadrilátero Ferrífero, Brasil, DNPM/DFPM, Avulso 81:31p.

Dorr, J. V. N. 1969. Physiographic, stratigraphic and structural development of the Quadrilatero Ferrífero, Minas Gerais, Brazil. USGS Prof. Paper 641-A, 109 pp.

Drake Jr., A. A., Morgan, B. A. 1980. Precambrian Plate Tectonics in the Brazilian Shield Evidence from the Pre-Minas rocks of the Quadrilatero Ferrifero, Minas Gerais. USGS Prof. Pap. 1119-B, B1-B19.

Eschwege, W. L. v. 1817. Idées générales sur la constitution géologique du Brésil. - Ann. Mines II, $238-240$

Eschwege, W. L. v 1822. geognosticsches Gemalde von Brasilien und wahrscheinliches Muttergestein der diamanten. - 44 p., Landes_Industries-Comptoirs, Weimar

Eschwege, W. L. v 1832. Beitrage zur Gebirgskunde Brasiliens. - 488 p., Reimer Verlag, Berlin

Fripp, R. E. P. 1976a. Stratabound Gold Deposits in Archaean Banded Iron-Formation, Rhodesia. Econ. Geol. v.71: $58-75$.

Fripp, R.E.P. 1976b. Gold metallogeny in the Archean of Rhodesia. In. B.F. Windley (Ed.) The Early History of the Earth, Wiley, London, 455-466.

Freyberg, B.V. 1932. Ergebnisse geologischer Forschungen in Minas Gerais (Brasilien) - N. Jb. Min., Sonderbd. 2, 403p.

Freyberg, B.V. 1934. Die Bodenschaetze des Staates Minas Gerais. 453p. Ed. Schweizerbart, Stuttgart.

Goodwin, A.M. 1962. Structure, Stratigraphy and Origin of Iron-Formation, Michipicoten Area, Algoma district, Ontario, Canada: Geol. Soc. America Bull., v. 73: 561 - 85.

Gromet, L.P.; Dymek, R.F.; Haskin, L.A. e Korotev, R.L. 1984. The "North American Shale Composite": its compilation, major and trace element characteristics. Geochim. Cosmochim. Acta, 48: 2469-2482.

Groos, G.A. 1965. Geology of Iron Deposits in Canada: Canada Geol. Survey Econ. Geol. Rept. 22, v. $1,181 \mathrm{p}$.

Groves, D.I., Phillips, G.N., Ho,S. E., Houston, S.M. 1985. The Nature, Genesis and Regional Controls of Gold mineralization in Archaean Greenstone Belts of the Western australian Shield: a Brief Review. Trans. Geol. soc. South africa, 14 p.

Groves, D.I e Batt, W.D. 1984 Spatial and temporal variations of Archean metallogenic associations in terms of evolution of granitoid-greenstone terrains with particular emphasis on Western 
Australia. In:A. Kröner, G.M. Hanson and A.M. Goodwin (eds), Archean Geochemistry. Springer-Verlag, Berlin, pp. 73-98.

Guimarães, D. 1970. Arqueogênese do ouro na região central de Minas Gerais. DNPM/DFPM, Rio de Janeiro, Bull. 139, 51 pp.

Guimarães, D. 1951. Arqui-Brasil e sua evolução geológica. - DNPM, Div. Fom. Prod. Miner., Bol. 88,314 p. Rio de Janeiro

Harder, E. C., Chamberlin, R. T. 1915. The Geology of Central Minas Gerais, Brazil. Journ of Geol. $23: 341-378$ and $385-424$.

Herz, N. 1970. Gneissic and igneous rocks of the Quadrilátero Ferrífero, Minas Gerais, Brazil. U. S. Geol. Surv. Prof. Paper 641B: 58 p.

Herz, N. 1978. Metamorphic rocks of the Quadrilátero Ferrífero, Minas Gerais, Brazil. U. S. Geol. Surv. Prof. Paper 641C: 81p.

Hodgson, C. J. 1989. The structure of shear-related, vein tipe gold deposits - A review: Ore Geology Reviews, v.4, p. 231-273.

Hutchinson, R. W. 1973. Volcanogenic sulphide deposits and their metallogenetic significance. Econ. Geol., 68: 1223-1246.

Hutchinson, R. W. 1993. A multi-stage, multi-process genetic hypothesis for greenstone-hosted gold lodes. Ore Geol. Reviews, Special Issue 8 (Vein-type Ore Deposits) : 349 - 382.

Hutchinson, R. W. e Burlington, J. L. 1984. Some broad characteristics of greenstone belt gold lodes. pp. 339-372 , in R. P. Foster (ed.) Gold'82: The Geology, Geochemistry and Genesis of Gold Deposits (Geol. Soc. Of Zimbabwe, Special publication 1) A.A.Balkema, Rotterdam, The Netherlands, 753p.

Inda, H. A. V., Schorscher, H. D., Dardenne, M. H., Schobbenhaus, C., Haralyi, N. L. E., Branco, P. C. A., Ramalho, R. 1984. O cráton do São Francisco e a Faixa de dobramentos Araçuai. In: Schobbenhaus, C., Campos, D. A., Derze, G. R. Asmus, H. E., (editores), Geologia do Brasil. Brasília DNPM-MME, p. 196 - 250.

James, H. L. 1954. Sedimentary facies of Iron Formation. Econ. Geol., v. 49:235 - 93.

Kerrich, R., Fryer, B. J. 1979. Archean Precious Metal Hydrothermal Systems, Dome Mine, Abitibi Greenstone belt. II. REE and oxygen isotope relations. Canada Jour. Earth Sci., v. 16: 440 58.

Ladeira, E. A. 1980. Metallogenesis of Gold at the Morro Velho Mine in Nova Lima District, Quadrilatero Ferrífero, Minas Gerais, Brazil. University of Western Ontario.

Umpubl. PhD. Thesis, 272 p, London, Ontario, Canada.

Ladeira, E. A. 1988. Metalogenia dos depósitos de ouro do quadrilátero Ferrífero, Minas Gerais. In: Schobbenhaus, C., Coelho, C. E. S. (Editores), Principais depósitos minerais do Brasil metais básicos não ferrosos, ouro e alumínio, 3: 301-375.

Ladeira, E. A. 1991a. (Editor), Brazil Gold'91, Balkerma, Rotterdam, 823 pp. 
Ladeira, E. A. 1991b. Genesis of gold in Quadrilátero Ferrífero: a remarkable case of permanency, recycling and inhiritance a tribute to Djalma Guimarães, Pierre Routhier and Hans Ramberg. In: Ladeira, E. A. (Editor), Brazil Gold'91, Balkerma, Rotterdam, 11-32.

Ladeira, E. A., e Roeser, H. P. M. 1983. Petrography of the Rio das Velhas Greenstone Belt, Quadrilátero Ferrífero, Minas Gerais, Brazil. Zbl. Geol. Miner., Teil 1, H 314, 430-445.

Ladeira, E. A., Viveiros, J. F. M. 1984. Hipótese sobre a estruturação do Quadrilátero Ferrífero com base nos dados disponíveis. Belo Horizonte, Soc. Bras. Geol. Núcleo de Minas Gerais, Bull. $4,18 \mathrm{pp}$.

Lobato, L.M e Vieira, F.W.R. 1998. Styles of hydrotermal alteration and gold mineralization associated with the Nova Lima Group os the Quadrilátero Ferrifero: Part II, The Archean mesothermal gold-bearing hydrotermal system. Rev. Bras. Geoc., 28(3): 355-366.

Lobato, L.M.; Vieira, F.W.R.; Ribeiro Rodrigues, L.C.; Pereira, L.M.M; Menezes, M.G.; Junqueira, P.A. e Martins Pereira, S.L. 1998. Styles of hydrotermal alteration and gold mineralization associated with the Nova Lima Group os the Quadrilatero Ferrifero: Part I, Description of selected gold deposits. Rev. Bras. Geoc., 28(3): 339-354.

Luchesi, I. 1991. Evolução Petrogenética e metalogenética da Serra da Boa Vista, Quadrilátero Ferrífero-MG. Diss. Mestrado, IG-USP, 134p.

Machado, N., Noce, C. M., Oliveira, O. A. B., Ladeira, E. A. 1989. Evolução Geológica do Quadrilátero Ferrífero no Arqueano E Proterozóico Inferior com base em geocronologia U/Pb. In: 5. Simpósio de Geologia de Minas Gerais, Belo Horizonte, 1989, Soc. Bras. Geol.. Núcleo Minas Gerais, c 1-5.

Martins Pereira, S. L. 1992. An overview on the geology of the São Bento gold deposit, Santa Bárbara, Minas Gerais. In: Gold deposit modeling course-IUGS-UNESCO, 1992, Brazil, ext. abstr. vol., 59-100.

Martins Pereira, S. L. 1995. Controles litoestruturais da mineralização aurífera do Distrito de Santa Bárbara, Quadrilátero Ferrífero, MG: Mina de São Bento. Unpub. M.Sc. Thesis, Univ. Fed. Minas Gerais, Belo Horizonte, $158 \mathrm{pp}$.

Mason, R. e Helmstaedt, H.H. 1992. Structural controls during formation and deformation of Archean lode-gold deposits in the Canadian Shield. In: International Basement tectonics Association Publication no 8, pp 625-631.

Menezes, M.G. 1996. Evolução mineralógica das encaixantes da mineralização Aurífera da Mina de Santana - Mariana - MG. In: SBG, Congr. Bras. Geol. , 39: Salvador, Anais. 3: 320-322.

Moraes, L. J. 1935. Notas preliminares sobre algumas jazidas metalíferas de Caeté e Santa Bárbara, Minas Gerais. DNPM internal report 583, Belo Horizonte, $10 \mathrm{pp}$.

Moraes, L. J., e Barbosa, O. 1939. Ouro no centro de Minas Gerais., DNPM/DFPM, Rio de Janeiro, Bull. 38, 197 pp.

Moreschi, J.B. 1972. Geologia da Mina de Ouro do Faria, Minas Gerais. - 115pp., Tese de Doutorado, IG-USP. 
Moseley, G. 1986. The Geology of the São Bento Gold Deposit. In: IBRAM-IUGS, Workshop on gold related to greenstone belts and base metals associated to volcanogenic rocks, Belo Horizonte, Field Trip Guide Book: 100 - 116.

Mothé $\mathrm{F}^{\circ}$, H.F. 1996. Contribuição à geologia da Quadrícula de Florália, Quadrilátero FerríferoMG. Diss. Mestrado, UFRJ, 212p., Rio de Janeiro.

Noce, C. M., Machado, N. e Teixeira, W. 1994. O Complexo Belo Horizonte e a evolução Arqueana do Quadrilátero Ferrífero, Minas Gerais. In: 38. Congresso Brasileiro de Geologia, Balneário Camboriú, 1994, ext. abstr. vol., SM03, 68-69.

Noce, C. M. 1995. Geocronologia dos eventos magmáticos, sedimentares e metamórficos na região do Quadrilátero Ferrífero, Minas Gerais. Unpub. Ph.D. Thesis, Univ. São Paulo, São Paulo, $128 \mathrm{pp}$.

Oliveira, O. A. B. 1984. As falhas de empurrão e suas implicações na estratigrafia e metalogenia do Quadrilátero Ferrífero-MG. In: Congresso Brasileiro de Geologia, Soc. Bras. Geol., Goiânia, 1984, ext. abstr. vol., 1074-1087.

Pereira, E. L. S. 1996. Controles e evolução da mineralização aurífera da Mina de São Bento, greenstone belt Rio das Velhas, MG. Unpub. M.Sc. Thesis, Univ. Fed. Ouro Preto, Ouro Preto.

Pflug, R. 1965: A geologia da parte meridional da Serra do Espinhaço e zonas adjacentes, Minas Gerais - DNPM. Div. Geol. Mineral. Bol. 226, 55 p., Rio de Janeiro.

Pflug, R. 1968: Observações sobre a estrtigrafia da Série Minas na Região de Diamantina, Minas Gerais. - DNPM Div. Geol. Mineral. Notas Prelim. E Est. 142, 20 p., Rio de Janeiro.

Pflug, R. e Renger, F. 1973: A evolução Geológica da margem SE do Cráton SanFranciscano. - In: $27^{\circ}$ Cong. Bras. Geol., Anais, v. 2, 5-19, Soc. Bras. Geol., Aracaju.

Phillips, G. N., Groves, D. I., Martyn, J. E. 1984. An Epigenetic Origin for Archaean Banded Iron Formation - Hosted Gold Deposits. Econ. Geol, v. $79: 162$ - 71 .

Prado, M. G. B., Pereira, S. L. M., Rodrigues, J. T. e Ribeiro, A. 1991. Synthesis of the geology of São Bento and Santa Quitéria Mines, Santa Bárbara, Minas Gerais. In: Fleischer, R.; et al. (ed.) field and mine trip to Quadrilátero Ferrífero, Minas Gerais, Brazil. Field Guide Book of Brazil Gold' 91: An International Symposiun on the Geology of Gold. Belo Horizonte, 1991: p. $41-74$.

Rettinger, R.; Schorscher, H.D.; OBERHANSLI, R. 1996. gotermobarometric correlation of geothermobarometers and petrogenetic modelling in NE-Quadrilátero Ferrífero, Minas Gerais, Brazil. Zbl. Geol. Palaont. Teil I,1994 (7/8): 613-625, Stuttgart.

Rettinger, R. 1998. Thermometamorphic characterization of the transition zone between the archean São Francisco Cráton and the Proterozoic mobile belt, Minas Gerais, Brazil. Tese Doutor., 116 p., Univ. Potsdam.

Ribeiro-Rodrigues, L. C., Friedrich, G., Oliveira, C. G., Vieira, F. W. R., Callegari, L. A., Biasi, E. E. 1995. Gold in Archean banded iron formations of the Iron Quadrangle, Minas Gerais, Brazil: The Cuiabá Mine. In: Geocongress 1995, Johanesburg, Geol. Soc. South Africa, ext. abstr. vol., 1: 146-149. 
Ribeiro-Rodrigues, L. C., Friedrich, G., Oliveira, C. G. 1996b. Gold Mineralization in Archean banded iron-formations in Brazil. In: 30. International Geological Congress Beijing, 1996, ext. abstr. vol., 3: 756.

Ribeiro-Rodrigues, L. C., Friedrich, G., Oliveira, C. G., Vieira, F. W. R., Callegari, L. A., Biasi, E. E. 1996c. The BIF-hosted Cuiabá Gold Deposit, Iron Quadrangle, Minas Gerais, Brazil: characteristics, controls and genesis. In: Gold Deposits of South America Symposium, 39. Congresso Brasileiro de Geologia, Salvador, 1996, vol. 7.

Ribeiro-Rodrigues, L. C., Vieira, F. W. R., Friedrich, G., Chemale Jr., F., Oliveira, C. G. 1997. Structural styles of greenstone-hosted gold mineralization in the Quadrilátero Ferrifero, Minas Gerais, Brazil. In: 6. Simpósio Nacional de Estudos Tectônicos (SNET), Brasília, 1997, ext. abstr. Vol., 363-366.

Rona, P e Scott, S.D 1993. A special issue on sea floor, hydrotermal mineralization: new perspectives. Econ. Geol. 88(8): 1935-1975.

Scarpelli, W. 1991. Aspects of gold mineralization in the Iron Quadrangle, Brazil. In: Ladeira, E. A. (Editor), Brazil Gold'91, Balkerma, Roterdam, 151-158.

Schobbenhaus, C. e Coelho, C.E.S. 1988. Principais Depósitos Minerais do Brasil, Vol. III, Metais Básicos não ferrosos, Ouro e Alumínio, DNPM, Brasília, 670p.

Schorscher, H. D. 1975. Entwicklung des polymetamorphen prakambrischen Raumes Itabira, Minas Gerais, Brasilien. Tese Doutor. , 304 p., 11 mapas, Miner. Petrog. Inst. , Univ. Heidelberg.

Schorscher, H.D. 1976a. Polimetamorfismo do Pré-Cambriano na região de Itabira, Minas Gerais, Brasil. - In: 29o Cong. Bras. Geol., Resumos: 194-195, SBG., Ouro Preto/Belo Horizonte.

Schorscher, H.D. 1976b: Alpinotype Deckentektonik im Präkambrium des Eisernen Vierecks, Minas Gerais, Brasilien. - In: 5. Geowiss. Lateinamerika-Kolloquium, Tagungsunterl.: 3335 , Clausthal-Zellerfeld.

Schorscher, H. D. 1978. Komatítos na Estrutura "Greenstone Belt" Série Rio das Velhas, Quadrilátero Ferrífero, Minas Gerais, Brasilien. In: Congresso Brasileiro de Geologia, 30 Recife (Resumo).

Schorscher, H. D. 1979. Evolução Geotectônica e Petrogenética do Embasamento Arqueano do Quadrilátero Ferrífero. Anais Acad. Bras. ci., 51: 767-8 (Resumo).

Schorscher, H.D. 1979b. Evolução arqueana e proterozóica do Quadrilátero Ferrífero e de partes meridionais da Serra do Espinhaço. - Simp. sobre a Geologia do Cráton do São Francisco e de suas faixas marginais, Resumos, Salvador.

Schorscher, H. D., Santana, F. C., Polonia, J. C., Moreira, J. M. P. 1982. Quadrilátero Ferrífero, Minas Gerais State: Rio das Velhs greenstone belt and Proterozoic rocks. In: International Symposium on Archean and Early Proterozoic geologic evolution and metallogenesis (ISAP), Sec. Minas e Energia, Bahia, excursion annex, 46 pp.

Schorscher, J.H.D.; Mothè Fo., H.F.; Davies, H.P.K.; Abreu, G.C.; Queiroga, N.C.M.1986. Metalogenia arqueana do ouro na Mina do Pari e arredores de Florália, MG. 34o Cong. Bras. Geol., Bol. 1 - Res. Breves Comun., p.232, Goiânia. 
Schorscher, J.H.D.; Abreu, G.C.; Queiroga N.C.M.; Luchesi, I.; Davies, H.P.K.; Mothè Fo., H.F.; Alves, M.G. 1990 Geologia da Quadrícula de Florália(1:25000), Quadrilátero Ferrífero, Minas Gerais. In: 360 Cong. Bras. Geol., Res. das comun., p.342, Natal.

Schorscher, H. D., Abreu, G. C., Luchesi, I., Queiroga, N. C. M., Sant'anna, L. G., Sá, E. L. 1991. Microgeoquímica do ouro arqueano e proterozóico na região E-NE do Quadrilátero Ferrífero e Itabira, MG. In: 3. Congresso Brasileiro de Geoquímica/ Congresso de Geoquímica de países de língua portuguesa, São Paulo, Soc. Bras. Geoq., 1991, guia de excursão, 574-577.

Schorscher, H. D. 1992. Arcabouço Petrográfico e Evolução Crustal de terrenos PréCambrianos do sudeste de M.G.: Quadrilátero Ferrífero, Espinhaço Meridional e domínios granitognássicos adjacentes. Tese de Livre-Docência, 2 vol., 394 págs., IG - USP, São Paulo, 1992.

Sichel, S. E. 1983. Geologia das rochas pré-cambrianas da região de Barão dos Cocais e geoquímica preliminar dos komatiítos do Supergrupo Rio das Velhas, Quadrilátero Ferrifero, MG. Unpub. M.Sc. Thesis, Univ. Fed. Rio de Janeiro, 232 pp.

Sichel, S. E. e Valença, J. G. 1983. Geologia do Arqueano da região de Santa Bárbara, Quadrilátero Ferrífero, MG. In: 2. Simpósio de Geologia de Minas Gerais, Soc. Bras. Geol., núcleo Minas Gerais, Belo Horizonte, 1983, ext. abstr. vol., 197-208.

Silva, L. C., Zucceti, M., Silva, S. L., Baltazar, O. F., Malouf, R. F., Silva, J. N. S. 1993. Antofilitacordierita "xistos" e outras paragêneses exóticas no greenstone belt Rio das Velhas (GBRV): possiveis origens e significados. CPRM internal report, Belo Horizonte, $20 \mathrm{pp}$.

Simmons, G. C.; Maxwell, C. H. 1961. Grupo Tamanduá da Série Rio das Velhas. DNPM/DGM, Bol. $21131 \mathrm{p}$.

Simmons, G. C. 1968. Geology and mineral resources of the Barão de Cocais area, Minas Gerais, Brazil. - USGS Prof. Pap. 341-H, 46 p., Washington.

Teixeira, W. 1985. A evolução geotectônica da porção meridional do Cráton do São Francisco com base em interpretações geocronológicas. Umpub. Ph.D. Thesis, Univ. São Paulo, São Paulo, $207 \mathrm{pp}$.

Valladares, F. B. 2000. Geologia e petro-metalogênese da mineralização de ouro da mina São Bento, Quadrilátero Ferrífero, MG. Monografia de Trabalho de Formatura, Universidade de São Paulo, 33 pp.

Winkler, H. G. F. 1976. Petrogenesis of metamorphic rocks. 4 ed. Springer-Verlag, Berlin. 334 p. 


\section{$\underline{\text { Tabelas }}$}

Tabela 1 - Resumo das descrições de afloramentos.

Tabela 5 - Resultados das análises realizadas por FRX.

Tabela 6 - Resultados de análises para ETR.

Tabela 7 - Análises realizadas por Fire Assay. 
Tabela 1 - Resumo das descrições de afloramentos

\begin{tabular}{|c|c|c|}
\hline Afloramento & Descrição & Dados Estruturais \\
\hline 1 & $\begin{array}{l}\text { Xisto grafitoso intercalado a metachert carbonático } \\
\text { alterado. }\end{array}$ & $\begin{array}{l}295 / 60 \\
152 / 45 \\
135 / 45 \\
\text { Frat.234/60 }\end{array}$ \\
\hline 2 & $\begin{array}{l}\text { Intercalaç̃̃es centimétricas a métricas de xistos } \\
\text { pelíticos, grafitosos e carbonáticos com Fm. } \\
\text { ferriferas e xistos máficos. Variações de cores: } \\
\text { cinza, vinho e bege. } \\
\text { Amostras: }\end{array}$ & $\begin{array}{l}130 / 60 \\
152 / 65 \\
144 / 65 \\
150 / 65 \\
\text { Frat. } 64 / 70 \\
60 / 65 \\
\text { Eixo cren. } 8 / 70 \\
\end{array}$ \\
\hline 3 & $\begin{array}{l}\text { Após o ponto anterior ocorre solo de coloração } \\
\text { vermelha (metabásica?). }\end{array}$ & \\
\hline $3 \mathrm{~A}$ & $\begin{array}{l}\text { Xisto grafitoso com níveis quartzosos } \\
\text { recristalizados sacaroidal finos. }\end{array}$ & $142 / 70$ \\
\hline 4 & $\begin{array}{l}\text { Contato gradacional entre xisto grafitoso clorita } \\
\text { xisto. }\end{array}$ & $\begin{array}{l}136 / 45 \\
.112 / 55\end{array}$ \\
\hline 5 & clorita xisto & $\begin{array}{l}129 / 45 \\
110 / 55 \\
132 / 65 \\
\text { Frat. 191/85 } \\
\text { Lin. est. } \\
120 / 45 \\
280 / 55 \\
\text { cliv. cren. 292/45 }\end{array}$ \\
\hline 6 & rocha metabásica & \\
\hline $6 \mathrm{~A}$ & $\begin{array}{l}\text { xistos de coloração cinza variando } \\
\text { gradacionalmente para xistos de coloração bege } \\
\text { (clorita-sericita xisto). }\end{array}$ & $110 / 50$ \\
\hline 7 & clorita-sericita xisto & \\
\hline $7 \mathrm{~A}$ & Sericita xisto & $152 / 35$ \\
\hline $7 \mathrm{~B}$ & clorita-sericita xisto & \\
\hline 8 & $\begin{array}{l}\text { Ponto de observação, quebra de relevo. } \\
\text { Neste ponto ocorre solo de coloração avermelhada. }\end{array}$ & \\
\hline 9 & $\begin{array}{l}\text { Intercalações métricas entre clorita xistos e sericita } \\
\text { xistos. }\end{array}$ & $110 / 60$ \\
\hline $9 \mathrm{~A}$ & sericita xisto & $\begin{array}{l}106 / 70 \\
110 / 65 \\
140 / 50\end{array}$ \\
\hline $9 \mathrm{~B}$ & $\begin{array}{l}\text { Intercalações centimétricas a métricas, verticais e } \\
\text { horizontatis de clorita xisto e xisto carbonoso. }\end{array}$ & \\
\hline 10 & clorita-sericita xisto & $128 / 50$ \\
\hline $10 \mathrm{~A}$ & clorita-sericita xisto & \\
\hline $10 \mathrm{~B}$ & clorita-sericita xisto & $\begin{array}{l}128 / 35 \\
\text { eixo cren. } 20 / 25 \\
\text { cliv. cren. } 268 / 60\end{array}$ \\
\hline $10 \mathrm{C}$ & Xisto grafitoso. & \\
\hline $10 \mathrm{D}$ & Clorita-sericita xisto & $145 / 52$ \\
\hline
\end{tabular}




\begin{tabular}{|c|c|c|}
\hline 11 & Clorita-sericita xisto & \\
\hline $11 \mathrm{~A}$ & Clorita-sericita xisto. Apresentando intercalaçס̃es & \\
\hline 12 & Talco-clorita xisto & \\
\hline $12 \mathrm{~A}$ & Talco-clorita xisto & \\
\hline $12 \mathrm{~B}$ & contato talco-clorita xisto com granodiorito & $130 / 58$ \\
\hline 13 & clorita-sericita xisto & \\
\hline 14 & granodiorito & \\
\hline 15 & granodiorito & \\
\hline 16 & clorita-sericita xisto & \\
\hline 17 & clorita-sericita xisto & $157 / 60$ \\
\hline 18 & cloritamsericita xisto & \\
\hline 19 & metabasito & \\
\hline 20 & contato entre metabasito e cloita xisto & \\
\hline 21 & conglomerado & \\
\hline 22 & conglomerado & \\
\hline 23 & clorita-sericita xisto & \\
\hline 24 & clorita-sericita xisto & $145 / 53 ; 150 / 47$ \\
\hline 25 & clorita-sericita xisto & \\
\hline 26 & clorita-sericita xisto & \\
\hline 27 & metabasito & \\
\hline 28 & clorita-sericita xisto & \\
\hline 29 & formação ferrífera bandada & \\
\hline 30 & clorita-sericita xisto & \\
\hline 31 & Talco-clorita xisto & \\
\hline 32 & Talco-clorita xisto & $147 / 53$ \\
\hline 33 & Talco-clorita xisto & \\
\hline 34 & contato entre talco-clorita xisto e granodiorito & \\
\hline 35 & clorita xisto & \\
\hline 36 & clorita xisto & \\
\hline 37 & clorita xisto & \\
\hline 38 & clorita xisto & \\
\hline 39 & $\begin{array}{l}\text { clorita xisto com presença de blocos rolados de } \\
\text { formação ferrífera }\end{array}$ & \\
\hline 40 & clorita xisto & \\
\hline $40 \mathrm{~A}$ & $\begin{array}{l}\text { clorita xisto com presença de blocos rolados de } \\
\text { formação ferrífera }\end{array}$ & \\
\hline 41 & clorita xisto & $124 / 59$ \\
\hline 42 & clorita-sericita xisto & \\
\hline
\end{tabular}




\begin{tabular}{|c|c|c|}
\hline 43 & clorita-sericita xisto & \\
\hline 44 & clorita-sericita xisto & \\
\hline 45 & clorita-sericita xisto & \\
\hline 46 & metabasito & \\
\hline 47 & sericita xisto & $134 / 50$ \\
\hline 48 & formação ferrífera & \\
\hline 49 & formação ferrífera & \\
\hline 50 & formação ferrífera & \\
\hline 51 & clorita-sericita xisto & $123 / 70$ \\
\hline 52 & clorita-sericita xisto & \\
\hline 53 & formação ferrífera & \\
\hline 54 & formação ferrífera & \\
\hline 55 & formação ferrífera & \\
\hline 56 & metabasito & \\
\hline 57 & clorita sericita xisto & $144 / 36 ; 132 / 57$ \\
\hline 58 & clorita sericita xisto & \\
\hline 59 & clorita sericita xisto & \\
\hline 60 & filito & \\
\hline 61 & filito & \\
\hline$\overline{62}$ & sericita xisto & \\
\hline 63 & filito & \\
\hline 64 & sericita xisto & \\
\hline 65 & itabirito & \\
\hline 66 & itabirito & \\
\hline 67 & itabirito & \\
\hline 68 & clorita-sericita xisto & \\
\hline 69 & clorita-sericita xisto & \\
\hline 70 & formação ferrifera & $145 / 47$ \\
\hline 71 & formação ferrífera & \\
\hline 72 & clorita xisto & \\
\hline 73 & clorita xisto & \\
\hline 74 & formação ferrífera & \\
\hline 75 & clorita xisto & \\
\hline 76 & clorita xisto & \\
\hline 77 & formação ferrífera & \\
\hline 78 & contato entre formação ferrifera e clorita xisto & $136 / 46$ \\
\hline 79 & clorita xisto & \\
\hline
\end{tabular}




\begin{tabular}{|c|c|c|}
\hline 80 & formação ferrífera & \\
\hline 81 & sericita-clorita xisto & \\
\hline 82 & formação ferr;ifera & \\
\hline$\overline{83}$ & formação ferr;ifera & \\
\hline 84 & metabasito & \\
\hline 85 & formação ferrífera & \\
\hline 86 & contato entre formação ferrifera e metabasito & \\
\hline 87 & clorita xisto & \\
\hline 88 & formação ferrífera & \\
\hline 89 & formação ferrífera & $145 / 59$ \\
\hline 90 & contato entre clorita xisto e formação ferrífera & \\
\hline 91 & formação ferrifera & \\
\hline 92 & formação ferrifera & \\
\hline 93 & formação ferrífera & \\
\hline 94 & formação ferrifera & \\
\hline 95 & conglomerado & \\
\hline 96 & clorita-sericita xisto & \\
\hline 97 & clorita-sericita xisto & $135 / 40$ \\
\hline 98 & clorita-sericita xisto & \\
\hline 99 & clorita-sericita xisto & \\
\hline 100 & clorita-sericita xisto & \\
\hline 101 & clorita-sericita xisto & \\
\hline 102 & clorita-sericita xisto & $140 / 60$ \\
\hline 103 & clorita-sericita xisto & \\
\hline 104 & formação ferrífera & \\
\hline 105 & xisto grafitoso & \\
\hline 106 & xisto grafitoso & \\
\hline 107 & clorita-sericita xisto & \\
\hline 108 & clorita-sericita xisto & \\
\hline 109 & clorita-sericita xisto & \\
\hline 110 & sericita xisto & \\
\hline 111 & clorita-sericita xisto & $130 / 42$ \\
\hline 112 & sericita $x$ isto & \\
\hline 113 & clorita-sericita xisto & \\
\hline 114 & clorita-sericita xisto & \\
\hline 115 & sericita xisto & \\
\hline 116 & contato entre formação ferrífera e clorita xisto & \\
\hline
\end{tabular}




\begin{tabular}{|c|c|c|}
\hline 117 & contato entre formação ferrifera e clorita xisto & $160 / 57$ \\
\hline 118 & formação ferrifera & \\
\hline 119 & contato entre formação ferrifera e clorita xisto & \\
\hline 120 & formação ferrífera & \\
\hline 121 & clorita xisto & \\
\hline 122 & formação ferrifera & \\
\hline 123 & formação ferrífera & $142 / 40$ \\
\hline 124 & clorita xisto & \\
\hline 125 & contato entre talco-clorita xisto e clorita xisto & $138 / 64$ \\
\hline 126 & clorita xisto & \\
\hline 127 & clorita xisto & \\
\hline 128 & clorita xisto & \\
\hline 129 & formação ferrifera & \\
\hline 130 & contato entre talco-clorita xisto e formação ferrífera & \\
\hline 131 & talco clorita xisto & \\
\hline 132 & talco clorita xisto & \\
\hline 133 & talco clorita xisto & $145 / 45$ \\
\hline 134 & talco clorita xisto & \\
\hline 135 & talco clorita xisto & \\
\hline 136 & talco clorita xisto & \\
\hline$\overline{137}$ & granodiorito & \\
\hline 138 & talco clorita xisto & \\
\hline 139 & talco clorita xisto & $146 / 60$ \\
\hline 140 & talco clorita xisto & \\
\hline 141 & talco clorita xisto & \\
\hline 142 & contato entre formação ferrifera e clorita xisto & \\
\hline 143 & clorita xisto & \\
\hline 144 & sericita clorita xisto & \\
\hline 145 & clorita xisto & \\
\hline 146 & clorita xisto & \\
\hline 147 & clorita xisto & \\
\hline 148 & formação ferrífera & \\
\hline 149 & sericita-clorita xisto & \\
\hline 150 & sericita-clorita xisto & \\
\hline 151 & sericita-clorita xisto & $157 / 46$ \\
\hline 152 & sericita-clorita xisto & \\
\hline 153 & sericita-clorita xisto & \\
\hline
\end{tabular}




\begin{tabular}{|c|c|c|}
\hline 154 & clorita xisto & $134 / 56$ \\
\hline 155 & clorita xisto & \\
\hline 156 & sericita-clorita xisto & \\
\hline 157 & sericita-clorita xisto & \\
\hline 158 & clorita xisto & \\
\hline 159 & clorita xisto & \\
\hline 160 & contato entre talco xisto e clorita-sericita xisto & \\
\hline 161 & contato entre talco xisto e clorita-sericita xisto & $124 / 52$ \\
\hline $161 \mathrm{~A}$ & talco-clorita xisto & \\
\hline $161 \mathrm{~B}$ & talco-clorita xisto & \\
\hline 162 & contato entre talco-clorita xisto e clorita xisto & \\
\hline 163 & clorita sericita xisto & \\
\hline 164 & clorita sericita xisto & \\
\hline 165 & clorita sericita xisto & \\
\hline 166 & clorita sericita xisto & \\
\hline 167 & clorita sericita xisto & \\
\hline 168 & $\begin{array}{l}\text { contato entre clorita sericita xisto e talco-clorita } \\
\text { xisto }\end{array}$ & $135 / 45$ \\
\hline 169 & clorita xisto & \\
\hline 170 & clorita xisto & \\
\hline 171 & xisto grafitoso & \\
\hline 172 & xisto grafitoso & \\
\hline 173 & formação ferrífera & $156 / 47$ \\
\hline 174 & clorita xisto & \\
\hline 175 & clorita xisto & \\
\hline 176 & clorita xisto & \\
\hline 177 & clorita xisto & \\
\hline 178 & clorita xisto & \\
\hline 179 & clorita xisto & \\
\hline 180 & formação ferrífera & \\
\hline 181 & formação ferrífera & \\
\hline 182 & formação ferrifera & \\
\hline 183 & talco xisto & \\
\hline 184 & talco xisto & \\
\hline 185 & talco-clorita xisto & $160 / 56$ \\
\hline 186 & clorita sericita xisto & \\
\hline 187 & clorita xisto & \\
\hline 188 & sericita xisto & \\
\hline
\end{tabular}




\begin{tabular}{|l|l|l|}
\hline 189 & clorita sericita xisto & $135 / 55$ \\
\hline 190 & clorita-sericita xisto & \\
\hline 191 & clorita xisto & \\
\hline 192 & clorita xisto & \\
\hline 193 & clorita xisto & $164 / 50 ; 172 / 43$ \\
\hline
\end{tabular}


Tabela 5 - Resultados das análises realizadas por FRX

\begin{tabular}{|c|c|c|c|c|c|c|c|c|c|c|c|c|c|c|c|c|}
\hline & & Lim. de Det. & SBi7-2 & SB17-3 & SB32 & SB35 & SB01 & SB11B-1 & SB11B-2 & SB17-1 & $\mathrm{X}-1$ & 60-TOPE & 42 & 40BASE & 33BASE & 33ABASE \\
\hline Total & $\%$ & 0.0 & 100.2 & 100.8 & 100.3 & 99.2 & 100.6 & 99.4 & 100.8 & 99.7 & 99.4 & 99.7 & 100.5 & 100.2 & 100.7 & 100.5 \\
\hline LOI & $\%$ & 0.0 & 11.2 & 19.6 & 11.7 & 3.7 & 5.3 & 28.1 & 9.8 & 22.4 & 1.5 & 12.2 & 12.9 & 15.9 & 12.4 & 4.9 \\
\hline $\mathrm{SiO}_{2}$ & $\%$ & 0.01 & 63.3 & 37.2 & 34.0 & 58.9 & 49.30 & 5.81 & 71.40 & 20.12 & 30.2 & 35.3 & 28.7 & 31.8 & 27.3 & 31.7 \\
\hline $\mathrm{TiO}_{2}$ & $\%$ & 0.001 & 0.00 & 0.04 & 0.45 & 0.62 & 0.910 & 0.080 & 0.000 & 0.090 & 0.3 & 0.22 & 0.31 & 0.19 & 0.03 & 0.22 \\
\hline $\mathrm{Al}_{2} \mathrm{O}_{3}$ & $\%$ & 0.02 & 0.44 & 1.04 & 10.6 & 13.9 & 26.51 & 1.82 & 0.39 & 2.22 & 7 & 5.01 & 6.06 & 3.96 & 0.84 & 4.21 \\
\hline $\mathrm{Fe}_{2} \mathrm{O}_{3}$ & $\%$ & 0.01 & 22.79 & 36.40 & 36.30 & 13.60 & 6.56 & 51.10 & 16.60 & 48.20 & 52.8 & 37.09 & 43.3 & 38.2 & 54.2 & 51 \\
\hline $\mathrm{MnO}$ & $\%$ & 6 & 2 & 3 & 8 & 9 & 0.0573 & 0.2495 & 0.0742 & 0.498 & 0.3848 & 0.4198 & 0.2982 & 0.425 & 0.5941 & 0.1884 \\
\hline $\mathrm{MgO}$ & $\%$ & 0.01 & 1.05 & 1.78 & 6.58 & 3.17 & 3.60 & 5.87 & 1.26 & 3.03 & 5.58 & 5.91 & 5.45 & 5.15 & 2.54 & 3.44 \\
\hline $\mathrm{CaO}$ & $\%$ & 0.01 & 1.32 & 4.14 & 0.39 & 1.20 & 1.12 & 5.35 & 1.14 & 2.65 & 1.38 & 2.07 & 1.83 & 3.17 & 2.39 & 2.16 \\
\hline $\mathrm{Na}_{2} \mathrm{O}$ & $\%$ & 0.02 & 0.01 & 0.02 & 0.02 & 3.03 & 0.86 & 0.20 & 0.01 & 0.03 & 0.02 & 0.58 & 0.64 & 0.49 & 0.14 & 0.85 \\
\hline $\mathrm{K}_{2} \mathrm{O}$ & $\%$ & 0.01 & 0.04 & 0.04 & 0.05 & 0.81 & 6.05 & 0.10 & 0.05 & 0.03 & 0.08 & 0.82 & 0.91 & 0.71 & 0.25 & 1.19 \\
\hline $\mathrm{P}_{2} \mathrm{O}_{5}$ & $\%$ & 0.005 & 0.000 & 0.140 & 0.030 & 0.030 & 0.110 & 0.160 & 0.000 & 0.100 & 0.04 & 0.03 & 0.11 & 0.08 & 0.04 & 0.42 \\
\hline$F$ & $\%$ & 0.4 & 0.0 & 0.2 & 0.0 & 0.0 & 0.0 & 0.0 & 0.0 & 0.0 & 0 & 0 & 0 & 0 & 0 & 0 \\
\hline AS & ppm & 20 & 17 & 26 & 30 & 18 & 216 & 1292 & 2 & 59 & 25 & 185 & 51 & 20 & 70 & 17 \\
\hline BA & ppm & 20 & 0 & 16 & 23 & 364 & 996 & 32 & 0 & 3 & 56 & 254 & 299 & 260 & 91 & 410 \\
\hline $\mathrm{CE}$ & ppm & 40 & 3 & 11 & 54 & 32 & 128 & 48 & 5 & 56 & 0 & 7 & 41 & 1 & 0 & 4 \\
\hline $\mathrm{CL}$ & $\mathrm{ppm}$ & 400 & 352 & 234 & 0 & 0 & 0 & 0 & 0 & 0 & 0 & 0 & 0 & 0 & 0 & 0 \\
\hline $\mathrm{CO}$ & ppm & 8 & 12 & 12 & 24 & 48 & 52 & 0 & 0 & 0 & 28 & 53 & 76 & 8 & 0 & 0 \\
\hline CR & ppm & 6 & 16 & 55 & 297 & 346 & 498 & 81 & 9 & 79 & 225 & 163 & 209 & 132 & 52 & 169 \\
\hline CS & ppm & 30 & 0 & 0 & 0 & 0 & 27 & 0 & 8 & 11 & 0 & 46 & 0 & 44 & 14 & 107 \\
\hline $\mathrm{CU}$ & & & & & & & 67 & 0 & 9 & 24 & & & & & & \\
\hline GA & ppm & 4 & 2 & 6 & 15 & 17 & 31 & 0 & 0 & 4 & 10 & 6 & 8 & 2 & 4 & 0 \\
\hline LA & $\mathrm{ppm}$ & 30 & 1 & 0 & 19 & 24 & 49 & 13 & 0 & 7 & 13 & 0 & 3 & 34 & 0 & 0 \\
\hline NB & ppm & 4 & 1 & 6 & 11 & 10 & 14 & 7 & 3 & 10 & 16 & 8 & 14 & 7 & 12 & 15 \\
\hline ND & ppm & 30 & 0 & 18 & 38 & 33 & 72 & 16 & 3 & 0 & 21 & 0 & 9 & 0 & 0 & 22 \\
\hline NI & ppm & 6 & 0 & 0 & 92 & 170 & 229 & 5 & 0 & 48 & 83 & 75 & 90 & 25 & 0 & 4 \\
\hline PB & ppm & 10 & 27 & 17 & 23 & 15 & 22 & 35 & 18 & 30 & 31 & 28 & 19 & 15 & 29 & 47 \\
\hline RB & $\mathrm{ppm}$ & 4 & 3 & 0 & 1 & 29 & 234 & 9 & 0 & 1 & 10 & 64 & 80 & 62 & 21 & 122 \\
\hline$s$ & $\%$ & 0.002 & 0.050 & 0.130 & 0.110 & 0.090 & 0.000 & 0.500 & 0.000 & 0.400 & 0.03 & 0.06 & 0.05 & 0 & 0.11 & 0.15 \\
\hline SN & ppm & 30 & 0 & 0 & 0 & 0 & 4 & 0 & 0 & 0 & 0 & 0 & 0 & 0 & 0 & 0 \\
\hline SR & $\mathrm{ppm}$ & 4 & 14 & 52 & 0 & 138 & 147 & 111 & 14 & 30 & 19 & 63 & 72 & 74 & 37 & 100 \\
\hline TA & ppm & 8 & 29 & 47 & 35 & 5 & 0 & 0 & 0 & 0 & 59 & 37 & 56 & 59 & 97 & 84 \\
\hline $\mathrm{TH}$ & $\mathrm{ppm}$ & 4 & 0 & 0 & 9 & 8 & 14 & 17 & 1 & 16 & 6 & 8 & 8 & 4 & 9 & 11 \\
\hline U & $\mathrm{ppm}$ & 6 & 2 & 9 & 17 & 0 & 1 & 25 & 0 & 30 & 12 & 18 & 19 & 22 & 22 & 28 \\
\hline V & $\mathrm{ppm}$ & 6 & 1 & 16 & 75 & 94 & 167 & 16 & 0 & 15 & 54 & 51 & 53 & 38 & 19 & 39 \\
\hline$w$ & & & & & & & 0 & 0 & 1 & 0 & & & & & & \\
\hline$Y$ & ppm & 4 & 0 & 5 & 14 & 17 & 29 & 0 & 0 & 2 & 12 & 10 & 12 & 5 & 7 & 17 \\
\hline $\mathrm{ZN}$ & ppm & 6 & 136 & 184 & 219 & 105 & 130 & 142 & 35 & 348 & 493 & 283 & 195 & 166 & 38 & 132 \\
\hline ZR & ppm & 4 & 2 & 13 & 136 & 145 & 230 & 29 & 0 & 24 & 90 & 53 & 73 & 53 & 14 & 67 \\
\hline
\end{tabular}


Tabela 6 - Resultados de análises para ETR (ug/g)

\begin{tabular}{|c|c|c|c|c|c|c|c|c|c|}
\hline Elemento & SB-0I & SB-03-1 & SB-32 & SB-35 & SB-11C-2 & SB-19B & SB-30B-1 & SB-31-1 & SB-05-2 \\
\hline $\mathrm{La}$ & 24.9 & 14.5 & 19.4 & 24.6 & 2.51 & 4.26 & 4.00 & 1.46 & 3.33 \\
\hline $\mathrm{Ce}$ & 49.6 & 29.2 & 40.8 & 47.8 & 4.32 & 7.84 & 6.12 & 2.96 & 5.72 \\
\hline Nd & 22.2 & 13.4 & 18.0 & 20.1 & 1.96 & 3.37 & 2.55 & 1.45 & 2.60 \\
\hline $\mathrm{Sm}$ & 4.82 & 2.93 & 3.43 & 3.91 & 0.436 & 0.685 & 0.465 & 0.371 & 0.555 \\
\hline $\mathrm{Eu}$ & 1.10 & 0.735 & 0.750 & 1.01 & 0.210 & 0.203 & 0.226 & 0.184 & 0.285 \\
\hline $\mathrm{Gd}$ & 4.81 & 2.80 & 2.82 & 3.62 & 0.500 & 0.683 & 0.533 & 0.385 & 0.569 \\
\hline Dy & 5.02 & 2.82 & 2.66 & 3.24 & 0.527 & 0.655 & 0.579 & 0.421 & 0.562 \\
\hline Ho & 0.999 & 0.545 & 0.554 & 0.627 & 0.116 & 0.142 & 0.136 & 0.088 & 0.116 \\
\hline Er & 2.97 & 1.66 & 1.58 & 1.86 & 0.360 & 0.429 & 0.429 & 0.272 & 0.347 \\
\hline $\mathrm{Yb}$ & 2.77 & 1.59 & 1.54 & 1.83 & 0.387 & 0.417 & 0.392 & 0.268 & 0.295 \\
\hline $\mathrm{Lu}$ & 0.408 & 0.249 & 0.227 & 0.274 & 0.059 & 0.062 & 0.061 & 0.040 & 0.047 \\
\hline ETRL & 102.5867 & 60.8276 & 82.4091 & 97.4522 & 9.4284 & 16.3563 & 13.3598 & 6.4321 & 12.4913 \\
\hline ETRP & 16.9796 & 9.6539 & 9.3814 & 11.4530 & 1.9483 & 2.3890 & 2.1307 & 1.4752 & 1.9358 \\
\hline$R L+R P$ & 119.5663 & 70.4816 & 91.7905 & 108.9053 & 11.3767 & 18.7452 & 15.4905 & 7.9073 & 14.4271 \\
\hline $\mathrm{RL} / \mathrm{RP}$ & 6.0418 & 6.3008 & 8.7844 & 8.5089 & 4.8394 & 6.8466 & 6.2703 & 4.3600 & 6.4526 \\
\hline
\end{tabular}




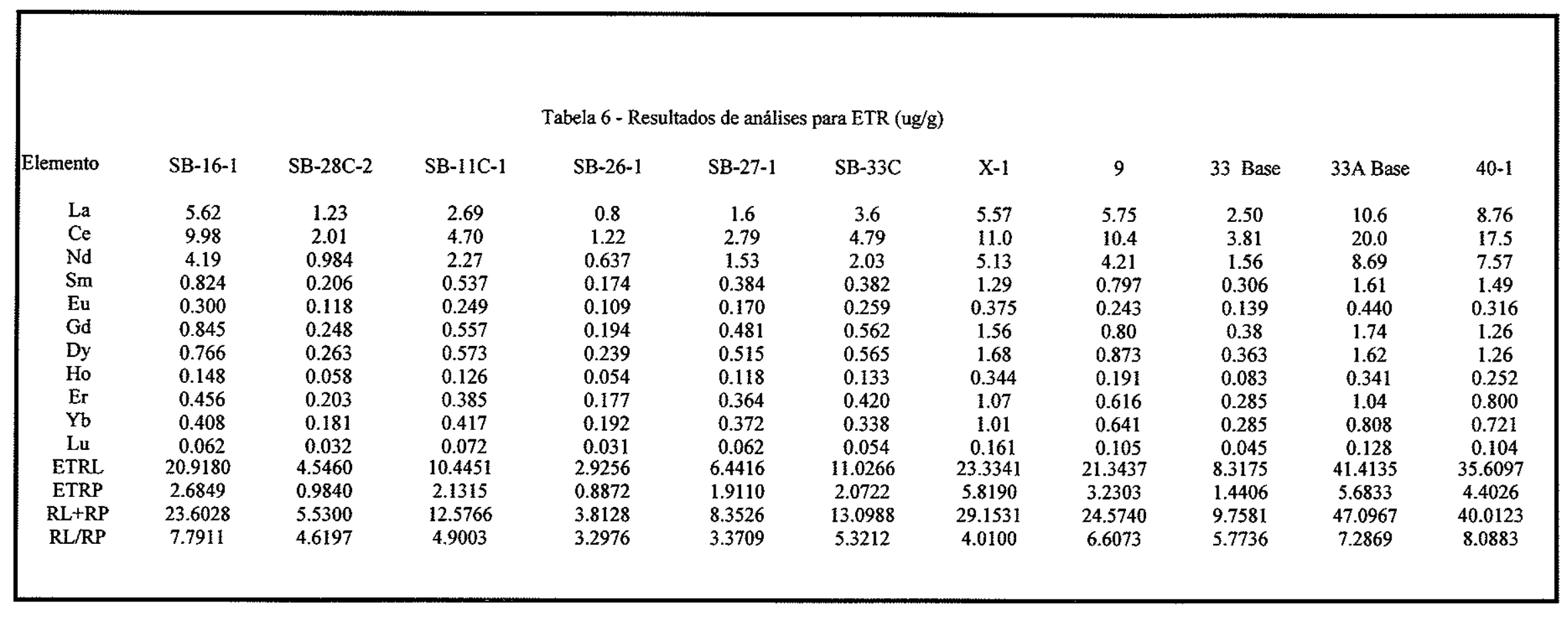




\begin{tabular}{|c|c|c|c|c|c|c|c|c|c|}
\hline \multicolumn{10}{|c|}{ Tabela 6 - Dados Para ETR Normalizado para NASC (ppm) } \\
\hline & SB-01 & SB-03-1 & SB-32 & SB-35 & SB-11C-2 & SB-19B & SB-30B-1 & SB-31-1 & SB-05-2 \\
\hline $\mathrm{La}$ & 0.7771 & 0.4542 & 0.6077 & 0.7680 & 0.0783 & 0.1331 & 0.1249 & 0.0458 & 0.1042 \\
\hline $\mathrm{Ce}$ & 0.6791 & 0.4006 & 0.5592 & 0.6549 & 0.0592 & 0.1074 & 0.0838 & 0.0406 & 0.0784 \\
\hline $\mathrm{Nd}$ & 0.6735 & 0.4055 & 0.5442 & 0.6104 & 0.0593 & 0.1022 & 0.0773 & 0.0439 & 0.0787 \\
\hline $\mathrm{Sm}$ & 0.8456 & 0.5143 & 0.6015 & 0.6864 & 0.0765 & 0.1201 & 0.0816 & 0.0652 & 0.0973 \\
\hline Eu & 0.8854 & 0.5924 & 0.6046 & 0.8140 & 0.1690 & 0.1634 & 0.1826 & 0.1487 & 0.2301 \\
\hline $\mathrm{Gd}$ & 0.9253 & 0.5378 & 0.5416 & 0.6971 & 0.0961 & 0.1313 & 0.1026 & 0.0741 & 0.1094 \\
\hline Dy & 0.8663 & 0.4855 & 0.4584 & 0.5582 & 0.0908 & 0.1129 & 0.0998 & 0.0727 & 0.0968 \\
\hline Ho & 0.9604 & 0.5241 & 0.5324 & 0.6028 & 0.1115 & 0.1368 & 0.1305 & 0.0850 & 0.1116 \\
\hline $\mathrm{Er}$ & 0.8736 & 0.4876 & 0.4660 & 0.5482 & 0.1058 & 0.1263 & 0.1263 & 0.0799 & 0.1020 \\
\hline $\mathrm{Yb}$ & 0.8925 & 0.5128 & 0.4972 & 0.5891 & 0.1248 & 0.1345 & 0.1266 & 0.0866 & 0.0953 \\
\hline $\mathrm{Lu}$ & 0.8491 & 0.5177 & 0.4735 & 0.5711 & 0.1232 & 0.1301 & 0.1269 & 0.0833 & 0.0974 \\
\hline $\mathrm{La} / \mathrm{Lu}$ & 0.9152 & 0.8774 & 1.2834 & 1.3449 & 0.6360 & 1.0231 & 0.9838 & 0.5496 & 1.0694 \\
\hline $\mathrm{La} / \mathrm{Sm}$ & 0.9189 & 0.8832 & 1.0103 & 1.1190 & 1.0247 & 1.1075 & 1.5304 & 0.7024 & 1.0703 \\
\hline $\mathrm{Gd} / \mathrm{Lu}$ & 1.0898 & 1.0388 & 1.1437 & 1.2206 & 0.7804 & 1.0098 & 0.8082 & 0.8896 & 1.1236 \\
\hline $\mathrm{Eu}^{*}$ & 0.8855 & 0.5261 & 0.5715 & 0.6917 & 0.0863 & 0.1257 & 0.0921 & 0.0696 & 0.1034 \\
\hline $\mathrm{Eu} / \mathrm{Eu}^{*}$ & 0.9999 & 1.1261 & 1.0578 & 1.1768 & 1.9586 & 1.2995 & 1.9829 & 2.1354 & 2.2257 \\
\hline $\mathrm{Ce}^{*}$ & 0.7425 & 0.4380 & 0.5865 & 0.7155 & 0.0720 & 0.1228 & 0.1090 & 0.0451 & 0.0957 \\
\hline $\mathrm{Ce} / \mathrm{Ce}^{*}$ & 0.9146 & 0.9147 & 0.9535 & 0.9153 & 0.8215 & 0.8746 & 0.7691 & 0.8994 & 0.8193 \\
\hline
\end{tabular}


Tabela 6 - Dados Para ETR Normalizado para NASC (ppm)

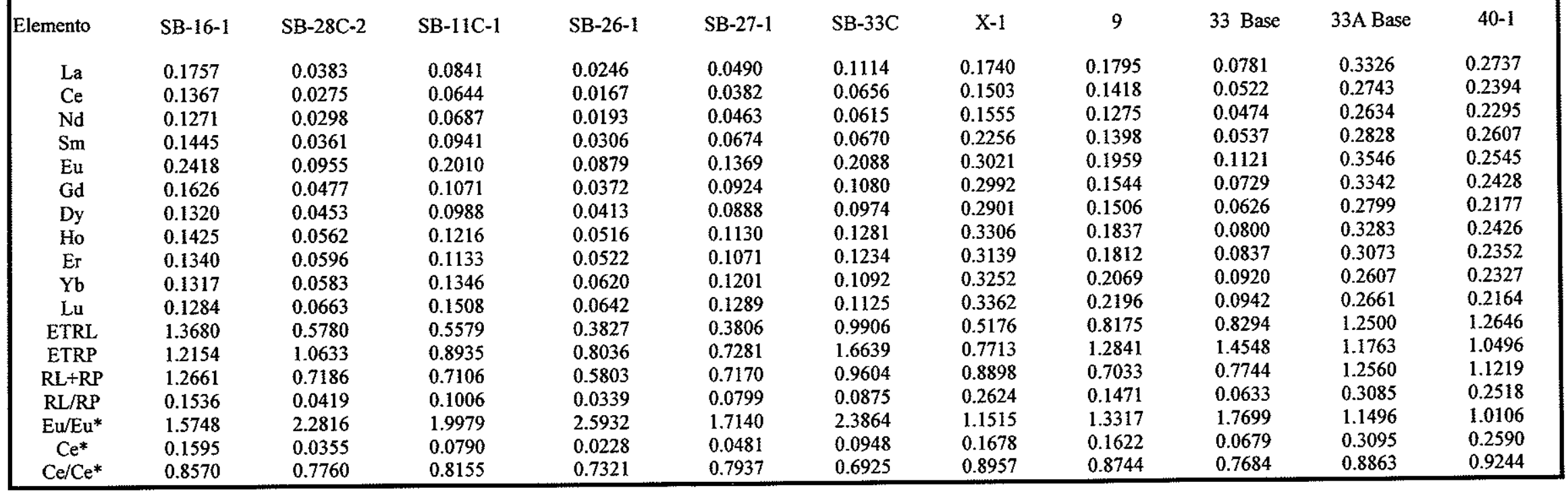


Tabela 7 - Análises realizadas por Fire Assay

\begin{tabular}{|cccc|}
\hline Amostra & Au ppm & S (\%) & As (\%) \\
SB - 02 & 0.30 & 0.67 & 0.06 \\
SB - 03 & 0.30 & 0.35 & 0.05 \\
SB - 04 & 0.35 & 1.64 & 0.35 \\
SB - 05 & 11.13 & 5.66 & 3.10 \\
SB - 06 & 9.34 & 4.50 & 4.35 \\
SB - 07 & 4.91 & 3.40 & 2.31 \\
SB - 09-1 & 17.27 & 13.10 & 6.71 \\
SB - 10 & 33.27 & 21.70 & 4.30 \\
SB - 13 - 1 & 8.03 & 3.15 & 5.20 \\
SB - 13 - 2 & 7.73 & 3.45 & 7.08 \\
SB - 15 - A & 16.09 & 6.20 & 8.74 \\
SB - 15 - B & 26.81 & 9.83 & 15.82 \\
SB - 15 - C & 20.24 & 8.00 & 12.51 \\
SB - 15 - D & 23.53 & 11.80 & 10.96 \\
SB - 22 - A & 0.35 & 0.85 & 0.26 \\
SB - 22 - D & 14.73 & 5.96 & 9.87 \\
SB - 23 & 32.97 & 14.00 & 13.95 \\
SB - 24 - A & 42.72 & 21.50 & 14.37 \\
SB - 24 - B & 23.72 & 17.70 & 10.97 \\
SB - 25 & 4.05 & 1.83 & 1.13 \\
SB - 27 & 18.74 & 7.62 & 6.81 \\
SB - 28 - B & 17.08 & 7.04 & 5.47 \\
SB - 30 - B & 2.31 & 3.30 & 0.73 \\
SB - 35 & 0.30 & 0.21 & 0.09 \\
\hline & & & \\
\hline
\end{tabular}




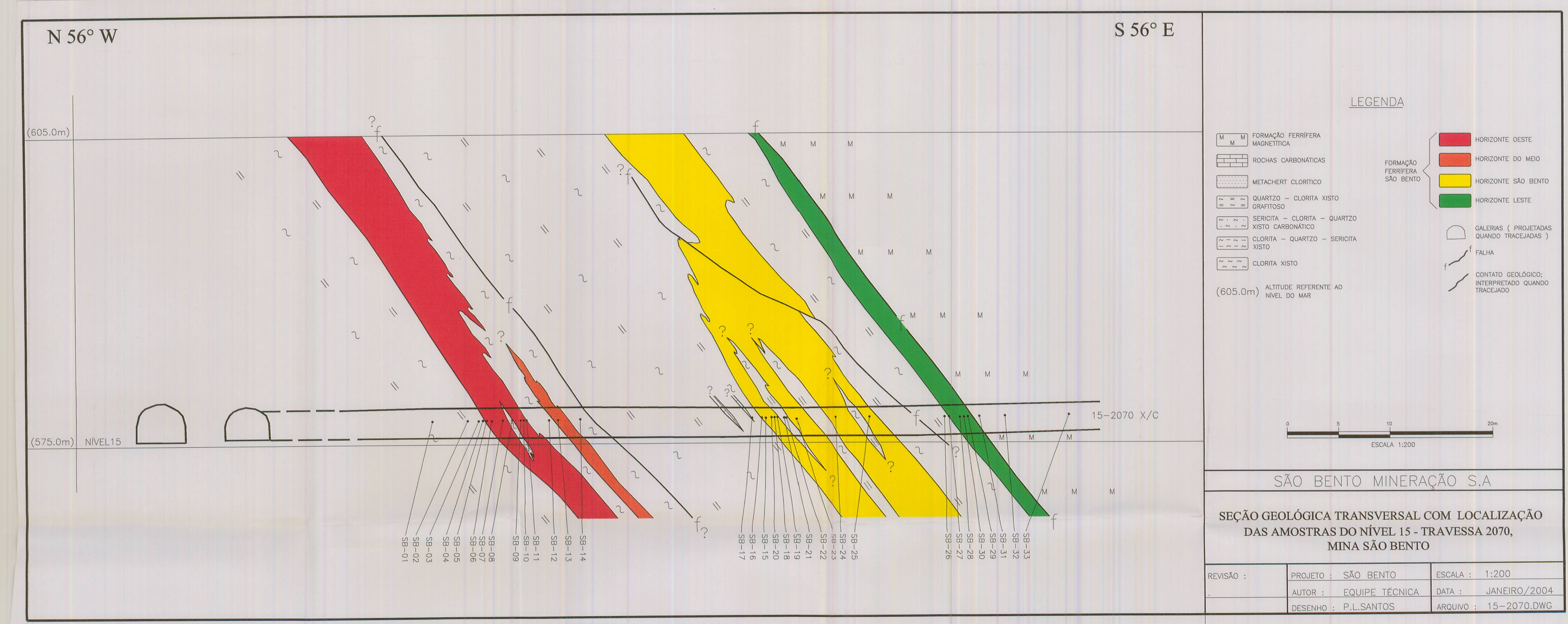




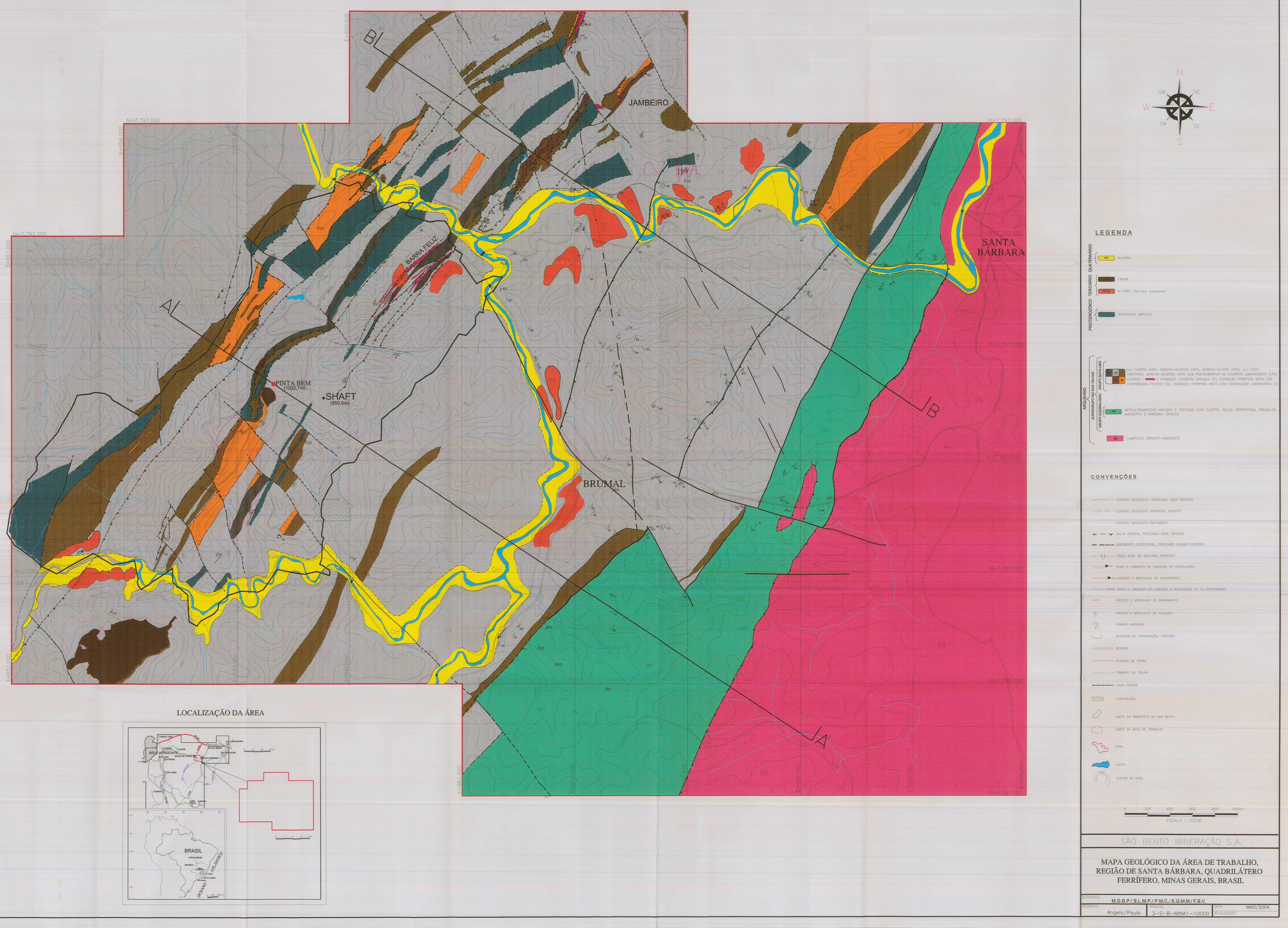




\title{
Anexo 3 \\ Tabela 2 - Ámostras, localização, lâminas e seções polidas
}

\author{
Tabela 3 - Microscopia petrográfica
}

Tabela 4 - Microscopia de minerais opacos 
Tabela 2 - Amostras, localização, lâminas e seções polidas

\begin{tabular}{|c|c|c|c|c|}
\hline $\begin{array}{c}\text { AMOSTRA } \\
\mathrm{N}^{\circ}\end{array}$ & LOCALIZAÇÅO & LÂMINA DELGADA & $\begin{array}{l}\text { LÂMINA DELGADA } \\
\text { POLIDA }\end{array}$ & SECÓES POLIDAS \\
\hline SB-01 & FORMAÇÅO GRAFITOSA BASAL & SB-01 & & \\
\hline SB-02 & FORMAÇĀO GRAFITOSA BASAL, MAIS PRÓXIMA DO CONTATO & SB-02 & & \\
\hline SB-03 & FORMAÇĀO GRAFITOSA BASAL JUNTO A ZONA DE TRANSIÇĀO & SB-03 & & \\
\hline SB-04 & FORMAÇĀO GRAFITOSA BASAL EM CONTATO COM CORPO OESTE & SB-04 & & \\
\hline \multirow[t]{2}{*}{ SB-05 } & $\begin{array}{l}\text { HORIZONTE OESTE } \\
\end{array}$ & & SB-05-1 & SB-05-1 \\
\hline & 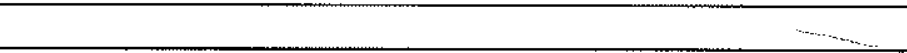 & & SB-05-2 & SB-05-2 \\
\hline SB-06 & HORIZONTE OESTE & SB-06 & & SB-06 \\
\hline \multirow[t]{3}{*}{ SB-07 } & HORIZONTE OESTE & SB-07-1 & & SB-07-1 \\
\hline & & SB-07-2 & & SB-07-2 \\
\hline & & SB-07-3 & & SB-07-3 \\
\hline $\mathrm{SB}-08$ & HORIZONTE OESTE & SB-08 & & $\mathrm{SB}-08$ \\
\hline \multirow[t]{2}{*}{$\mathrm{SB}-09$} & HORIZONTE OESTE & & SB-09-1 & SB-09-1 \\
\hline & & & SB-09-2 & $\mathrm{SB}-09-2$ \\
\hline \multirow[t]{2}{*}{ SB-10 } & HOREONTE OESTE & & SB-10-1 & SB-10-1 \\
\hline & & $\bar{c}$ & SB-10-2 & SB-10-2 \\
\hline SB-11A & HORIZONTE OESTE & & SB-11A & SB-11A \\
\hline SB-11B & ESTÉRILINTERCALADO & SB-11B & & SB-11B \\
\hline \multirow[t]{3}{*}{ SB-11C } & ESTÉRIL INTERCALADO & SB-11C-1 & & SB-11C-1 \\
\hline & & SB-11C-2 & & SB-11C-2 \\
\hline & & SB-11C-3 & & SB-11C-3 \\
\hline SB-12 & ESTÉRIL INTERCALADO & SB-12 & & \\
\hline \multirow[t]{2}{*}{ SB-13 } & HORIZONTE MIDDLE & SB-13-1 & & SB-13-1 \\
\hline & & SB-13-2 & & SB-13-2 \\
\hline SB-14 & ESTERIL INTERCALADO & SB-14 & & \\
\hline \multirow[t]{3}{*}{ SB-15A } & HORIZONTE SÁO BENTO & & SB-15A-1 & SB-15A-1 \\
\hline & & & SB-15A-2 & SB-15A-2 \\
\hline & & & SB-15A-3 & \\
\hline
\end{tabular}


Tabela 2 - Continuação

\begin{tabular}{|c|c|c|c|c|}
\hline $\begin{array}{c}\text { AMOSTRA } \\
\mathrm{N}^{\circ}\end{array}$ & LOCALIZAÇÃO & LÂMINA DELGADA & $\begin{array}{l}\text { LÂMINA DELGADA } \\
\text { POLIDA }\end{array}$ & SECÕES POLIDAS \\
\hline SB-15B & HORIZONTE SÄO BENTO & SB-15B & & \\
\hline \multirow[t]{2}{*}{ SB-15C } & HORIZONTE SÅO BENTO & & SB-15C-1 & SB-15C-1 \\
\hline & & & SB-15C-2 & SB-15C-2 \\
\hline SB-15D & HORIZONTE SÅO BENTO & SB-15D & & \\
\hline SB-16 & HORIZONTE SĀO BENTO & SB-16 & & \\
\hline SB-17 & ESTERIL INTERCALADO & SB-17 & & \\
\hline \multirow[t]{2}{*}{ SB-18 } & HORIZONTE SĀO BENTO & SB-18-1 & & \\
\hline & & SB-18-2 & & \\
\hline SB-19A & HORIZONTE SÁO BENTO & SB19A & & \\
\hline SB-19B & HORIZONTE SÁO BENTO & SB-19B & & \\
\hline SB-20A & HORIZONTE SÁO BENTO & & & \\
\hline SB-20B & HORIZONTE SĀO BENTO & & & \\
\hline \multirow[t]{2}{*}{ SB-2OC } & HORIZONTE SĀO BENTO & $S B-20 C-1$ & & \\
\hline & & SB-20C-2 & & \\
\hline SB-21A & HORIZONTE SẢO BENTO & SB-21A & & \\
\hline SB-21B & HORIZONTE SÅO BENTO & SB-21B & & \\
\hline SB-22A & HORIZONTE SÅO BENTO & SB-22A & & \\
\hline SB-22B & HORIZONTE SẢO BENTO & & & \\
\hline SB-22C & HORIZONTE SÃO BENTO & SB-22C & & \\
\hline SB-22D & HORIZONTE SÅO BENTO & SB-22D & & \\
\hline SB-23 & HORIZONTE SĂO BENTO & SB-23 & & \\
\hline SB-24A & HORIZONTE SÁO BENTO & SB-24A & & \\
\hline \multirow[t]{2}{*}{ SB-24B } & HORIZONTE SÄO BENTO & SB-24B-1 & & \\
\hline & & SB-24B-2 & & \\
\hline SB-25 & CONTATO HORIZONTE SÃO BENTO/ESTÉRIL INTERCALADO & SB-25 & & \\
\hline \multirow[t]{2}{*}{ SB-26 } & CONTATO ESTÉRIL INTERCALADO COM HORIZONTE LESTE & SB26-1 & & \\
\hline & & SB-26-2 & & \\
\hline \multirow[t]{3}{*}{ SB-27 } & TRANSIÇÃO DE ESTÉRIL INTERCALADO COM HORIZONTE LESTE & SB-27-1 & & \\
\hline & & SB-27-2 & & \\
\hline & & SB-27-3 & & \\
\hline
\end{tabular}


Tabela 2- continuação

\begin{tabular}{|c|c|c|c|c|}
\hline $\begin{array}{c}\text { AMOSTRA } \\
\mathrm{N}^{\circ} \\
\end{array}$ & LOCALIZAÇĀO & LÂMINA DELGADA & $\begin{array}{l}\text { LÂMINA DELGADA } \\
\text { POLIDA }\end{array}$ & SECOES POLIDAS \\
\hline SB-28A & HORIZONTE LESTE & SB-28A & & \\
\hline SB-28B & HORIZONTE LESTE & SB-28B & & \\
\hline SB-28C & HORIZONTE LESTE & SB-28C & & \\
\hline SB-28D & HORIZONTE LESTE & SB-28D & & \\
\hline SB-29A & HORIZONTE LESTE & SB-29A & & \\
\hline SB-29B & HORIZONTE LESTE & SB-29B & & \\
\hline SB-30A & HORIZONTE LESTE & SB-30A & & \\
\hline \multirow[t]{2}{*}{ SB-30B } & $\begin{array}{l}\text { CONTATO ENTRE HORIZONTE LESTE E MEMBRO FERRIFFERO DO } \\
\text { TOPO }\end{array}$ & SB-30B-1 & & \\
\hline & & SB-30B-2 & & \\
\hline SB-30C & $\begin{array}{c}\text { CONTATO ENTRE HORIZONTE LESTE E MEMBRO FERRIFERO DO } \\
\text { TOPO }\end{array}$ & SB-30C & & \\
\hline \multirow[t]{2}{*}{ SB-31 } & MEMBRO FERRIFERO DO TOPO & SB-31-1 & & \\
\hline & & SB-31-2 & & \\
\hline SB-32 & XISTO CLORÍTICO INTERCALADO NO MEMBRO FERRIFERO & SB-32 & & \\
\hline SB-33A & MEMBRO FERRIFERO DO TOPO & SB-33A & & \\
\hline SB-33B & MEMBRO FERRIFERO DO TOPO & SB-33B & & \\
\hline SB-33C & MEMBRO FERRIFERO DO TOPO & SB-33C & & \\
\hline SB-34 & VEIO REMOBILIZADO & & & \\
\hline SB-35 & FORMAÇĀO CARRAPATO & SB-35 & & \\
\hline $\mathrm{L}-17$ & MEMBRO FERRIFERO DO TOPO & $\mathbf{L - 1 7}$ & & \\
\hline$L-61$ & MEMBRO FERRIFERO DO TOPO & $L-61$ & & \\
\hline $1-62$ & MEMBRO FERRIFERO DO TOPO & L-62 & & \\
\hline$L-63$ & MEMBRO FERRIFERO DO TOPO & $L-63$ & & \\
\hline$L-64$ & MEMBRO FERRIFERO DO TOPO & $L-64$ & & \\
\hline
\end{tabular}




\section{Legenda da tabela 3:}

Microscopia petrográfica:

Nºâm. - Número da Lâmina

№ Am. - Número da Amostra

Abreviações quanto à mineralogia:
Qz. - Quartzo
Ca. - Carbonato
Cl. - Clorita
Ser. - Sericita
Op. - Opacos
Musc. - Muscovita
Turm. - Turmalina
Estilp. - Estilpnomelana

Abreviações quanto à percentagens:

P - $50 \%$ a $30 \%$

$\mathrm{Ma}-25 \%$ a $15 \%$

$\mathrm{Me}-10 \%$ a $5 \%$

$\mathrm{T}-3 \%$ a $1 \%$

Abundância relativa dos minerais constitutivos.

Legenda da tabela 4:

Microscopia de minerais opacos:

No Lâm. - Número da Lâmina

No Am. - Número da Amostra

Abreviações quanto à mineralogia:

Ars. - Arsenopirita

Pirrot. - Pirrotita

Pi. - Pirita

Calco. - Calcopirita

Mag. - Magnetita

Esf. - Esfalerita

Abreviações quanto à percentagens:

P - $50 \%$ a $30 \%$

$\mathrm{Ma}-25 \%$ a $15 \%$

Me $-10 \%$ a $5 \%$

$\mathrm{T}-3 \%$ a $1 \%$

P - Principal opaco ocorrente na seção polida descrita;

Ma - Segundo mineral em abundância;

Me - Terceiro mineral em abundância;

$\mathrm{T}$ - Mineral com menor quantidade.

Dados semi-quantitativos obtidos através das abundâncias relativas entre os minerais opacos totais em cada seção descrita 
Tabela 3 - Microscopia petrográfica

\begin{tabular}{|c|c|c|c|c|c|c|c|c|c|}
\hline$N^{\circ}$ Lâm. & $\mathrm{N}^{\circ} \mathrm{Am}$. & Qz. & Ca. & $\mathrm{Cl}$. & Ser. & Musc. & Op. & Turm. & Estilp. \\
\hline SB-01 & SB-01 & $P$ & $P$ & $\mathrm{Me}$ & $\mathrm{Ma}$ & & $\mathrm{Me}$ & & \\
\hline SB-02 & SB-02 & $P$ & $P$ & $\mathrm{Me}$ & $\mathrm{Me}$ & & $\mathrm{Ma}$ & & \\
\hline SB-03 & SB-03 & $P$ & $P$ & $\mathrm{Me}$ & $\mathrm{Me}$ & & $\mathrm{Me}$ & & \\
\hline SB-04 & SB-04 & $P$ & $\mathrm{P}$ & $\mathrm{Me}$ & $\mathrm{Me}$ & & $\mathrm{Ma}$ & & \\
\hline SB-05-1 & SB-05 & $P$ & $P$ & & $\mathrm{Me}$ & Me & $\mathrm{Ma}$ & $T$ & \\
\hline SB-05-2 & SB-05 & $P$ & $P$ & $\mathrm{Me}$ & & & $P$ & & \\
\hline SB-06 & SB-06 & $P$ & $P$ & & Me & & $\mathrm{Ma}$ & & \\
\hline SB-07-1 & SB-07 & $P$ & $\mathrm{P}$ & & $\mathrm{Me}$ & & $\mathrm{Ma}$ & & \\
\hline SB-07-2 & SB-07 & $P$ & $P$ & & $\mathrm{Me}$ & & $\mathrm{Me}$ & & \\
\hline SB-07-3 & SB-07 & $P$ & $P$ & & $\mathrm{Me}$ & & $\mathrm{Me}$ & & \\
\hline SB-08 & SB-08 & $P$ & $P$ & & $\mathrm{Me}$ & & $\mathrm{Ma}$ & & \\
\hline SB-09-1 & SB-09 & $P$ & $\mathrm{Ma}$ & $\mathrm{Me}$ & $\mathrm{Me}$ & & $\mathrm{P}$ & & \\
\hline SB-09-2 & SB-09 & $P$ & $P$ & & $\mathrm{~T}$ & $\mathrm{Me}$ & $\mathrm{Me}$ & & \\
\hline SB-10-1 & SB-10 & $\mathrm{P}$ & $P$ & $\mathrm{Me}$ & $\mathrm{T}$ & & $\mathrm{P}$ & & \\
\hline SB-10-2 & SB-10 & $P$ & $P$ & $\mathrm{Me}$ & $T$ & & $\mathrm{P}$ & & \\
\hline SB-11A & SB-11A & $P$ & $P$ & $\mathrm{Ma}$ & & $T$ & $\mathrm{Ma}$ & & \\
\hline SB-11B & SB-11B & $P$ & $\mathrm{P}$ & $\mathrm{Me}$ & $\mathrm{Me}$ & & Ma & & \\
\hline SB-11C-1 & SB-11C & $P$ & $\mathrm{P}$ & & $\mathrm{Me}$ & & $\mathrm{Ma}$ & & \\
\hline SB-11C-2 & SB-11C & $P$ & $P$ & & $\mathrm{Me}$ & & $\mathrm{Me}$ & & \\
\hline SB-11C-3 & SB-11 & $P$ & $P$ & $\mathrm{Me}$ & $\mathrm{Me}$ & & $T$ & & \\
\hline SB-12 & SB-12 & $P$ & $P$ & $\mathrm{Me}$ & $\mathrm{Me}$ & & & & \\
\hline SB-13-1 & SB-13 & $P$ & $P$ & & $\mathrm{Me}$ & & $\mathrm{Me}$ & & \\
\hline SB-13-2 & SB-13 & $P$ & $P$ & & $\mathrm{Me}$ & & $\mathrm{Me}$ & & \\
\hline SB-14 & SB-14 & $P$ & $P$ & & $\mathrm{Me}$ & & $\mathrm{Ma}$ & & \\
\hline SB-15A-1 & SB-15A & $P$ & $P$ & $\mathrm{Ma}$ & $\mathrm{Me}$ & & $\mathrm{Ma}$ & & \\
\hline SB-15A-2 & SB-15A & $P$ & $P$ & $\mathrm{Ma}$ & $T$ & & $\mathrm{Me}$ & & \\
\hline SB-15A-3 & SB-15A & $P$ & $P$ & $\mathrm{Ma}$ & $T$ & & $\mathrm{Me}$ & & \\
\hline SB-15B & SB-15B & $P$ & $\mathrm{P}$ & $\mathrm{Me}$ & $T$ & & $\mathrm{Ma}$ & & \\
\hline SB-15C-1 & SB-15C & $P$ & $\mathrm{P}$ & $\mathrm{Me}$ & $\mathrm{Ma}$ & & $\mathrm{Ma}$ & & \\
\hline SB-15C-2 & SB-51C & $P$ & $P$ & $\mathrm{Ma}$ & $\mathrm{Ma}$ & & $\mathrm{Me}$ & & \\
\hline
\end{tabular}




\begin{tabular}{|c|c|c|c|c|c|c|c|c|c|}
\hline $\mathrm{N}^{\circ}$ Lâm. & $\mathrm{N}^{\circ} \mathrm{Am}$ & Qz. & Ca. & $\mathrm{Cl}$. & Ser. & Musc. & Op. & Turm. & Estilp. \\
\hline SB-15D & SB-15D & $\mathbf{P}$ & $P$ & $\mathrm{Ma}$ & $\mathrm{Me}$ & & & & \\
\hline SB-16 & SB-16 & $P$ & $P$ & $\mathrm{Ma}$ & & & $\mathrm{Ma}$ & & \\
\hline SB-17 & SB-17 & $P$ & $\mathbf{P}$ & $T$ & & & $\mathrm{~T}$ & & \\
\hline SB-18 -1 & SB-18 & $P$ & $P$ & & $\mathrm{Ma}$ & $\mathrm{Me}$ & $\mathrm{T}$ & & \\
\hline SB-18-2 & SB-18 & $P$ & $P$ & & $\mathrm{Me}$ & & $T$ & & \\
\hline SB-19A & SB-19A & $P$ & $P$ & & & $\mathrm{~T}$ & $T$ & & \\
\hline SB-19B & SB-19B & $P$ & $P$ & & & $\mathrm{Me}$ & & & \\
\hline SB-20C-1 & SB-20C & $\mathrm{P}$ & $P$ & & $\mathrm{Me}$ & & $\mathrm{Me}$ & & \\
\hline SB-20C-2 & SB-20C & $P$ & $P$ & & & me & $\mathrm{Ma}$ & & \\
\hline SB-21A & SB-21A & $\mathrm{P}$ & $P$ & & & ME & $T$ & & \\
\hline SB-21B & SB-21B & $\bar{P}$ & P & & MA & & $\mathrm{T}$ & & \\
\hline SB-22A & $\mathrm{SB}-22 \mathrm{~A}$ & $P$ & $P$ & & & ME & $\mathrm{ME}$ & & \\
\hline SB-22C & SB-22C & $P$ & $P$ & ME & & & $\mathrm{MA}$ & & \\
\hline SB-22D & SB-22D & $P$ & $\mathrm{P}$ & & & $\mathrm{ME}$ & MA & & \\
\hline SB-23 & SB-23 & $P$ & $\mathrm{P}$ & $T$ & & $\mathrm{ME}$ & $\overline{\mathrm{MA}}$ & & \\
\hline SB-24A & SB-24A & MA & $P$ & $T$ & & ME & $\mathrm{P}$ & & \\
\hline SB-24B-1 & SB-24B & $P$ & $\mathrm{P}$ & $T$ & & $T$ & $P$ & & \\
\hline SB-24B-2 & SB-24B & $\mathrm{P}$ & $P$ & & & & & & \\
\hline SB-25 & SB-25 & $P$ & $P$ & & & & & & \\
\hline SB-26-1 & SB-26 & $P$ & $P$ & & & & & & \\
\hline SB-26-2 & SB-26 & $P$ & $\mathrm{P}$ & & & & & & \\
\hline SB-27-1 & SB-27 & $P$ & $P$ & & & & & & \\
\hline SB-28A & SB-27 & $P$ & $\mathrm{P}$ & & & & & & \\
\hline SB-28B & SB-27 & $P$ & $\mathrm{P}$ & & & & & & \\
\hline $\mathrm{SB}-28 \mathrm{C}$ & SB-28B & $\mathrm{P}$ & $\mathrm{P}$ & & & & & & \\
\hline SB-28D & SB-28C & $P$ & $P$ & & & & & & \\
\hline SB-29A & SB-29A & $P$ & $P$ & & & & & & \\
\hline SB-29B & SB-29B & $\mathrm{P}$ & $P$ & & & & & & \\
\hline SB-30A & SB-30A & $P$ & $P$ & & & & & & \\
\hline SB-30B-1 & SB-30B & $P$ & $P$ & & & & & & \\
\hline SB-30B-2 & SB-30B & $P$ & $P$ & & & & & & \\
\hline
\end{tabular}




\begin{tabular}{|c|c|c|c|c|c|c|c|c|c|}
\hline $\mathrm{N}^{\circ}$ Lâm. & $\mathrm{N}^{\circ} \mathrm{Am}$ & Qz. & Ca. & $\mathrm{Cl}$. & Ser. & Musc. & Op. & Turm. & Estilp. \\
\hline SB-30C & SB-30C & $P$ & $P$ & & & & & & \\
\hline SB-31-1 & SB-31 & $\mathrm{P}$ & $P$ & & & & & & \\
\hline SB-31-2 & SB-31 & $P$ & $\mathrm{P}$ & & & & & & \\
\hline SB-32 & SB-32 & $P$ & MA & & & & & & \\
\hline SB-33A & SB-33A & $P$ & $\mathrm{P}$ & & & & & & \\
\hline SB-33B & SB-33B & $P$ & $\mathrm{P}$ & & & & & & \\
\hline SB-33C & SB-33C & $P$ & $P$ & & & & & & \\
\hline SB-35 & SB-35 & $\mathrm{P}$ & $\mathrm{MA}$ & & 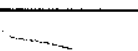 & & & & \\
\hline $\mathrm{L}-17$ & $x-1$ & MA & $\mathrm{P}$ & $\mathbf{P}$ & & & $\mathrm{T}$ & & $\mathrm{ME}$ \\
\hline$L-61$ & 9 & $P$ & $P$ & MA & & & $\mathrm{MA}$ & & MA \\
\hline L-62 & 33 BASE & $P$ & MA & $\mathrm{ME}$ & & & MA & & ME \\
\hline$L-63$ & 33A BASE & $P$ & MA & $\mathrm{ME}$ & & ME & $\mathrm{ME}$ & & $\mathrm{ME}$ \\
\hline$L-64$ & $40-1$ & $P$ & MA & $\mathrm{ME}$ & & & ME & & $\mathrm{P}$ \\
\hline
\end{tabular}


Tabela 4 - Microscopia de minerais opacos

\begin{tabular}{|c|c|c|c|c|c|c|c|}
\hline $\mathrm{N}^{\circ}$ Lâm. & $\mathrm{N}^{\circ} \mathrm{Am}$. & Ars. & Pirrot. & $\mathrm{Pi}$. & Calco. & Mag. & Esf. \\
\hline SB-05-1 & SB-05 & $P$ & $P$ & $\mathrm{Ma}$ & Me & $\mathrm{T}$ & $\mathrm{T}$ \\
\hline SB-05-2 & SB-05 & $P$ & $\mathrm{Me}$ & $\mathrm{Ma}$ & $T$ & $\mathrm{Me}$ & $\mathrm{T}$ \\
\hline SB-06 & SB-06 & $\mathrm{P}$ & $P$ & & $T$ & & \\
\hline SB-07-1 & SB-07 & $\mathrm{Ma}$ & $P$ & $\mathrm{Me}$ & $T$ & & \\
\hline SB-07-2 & SB-07 & $\mathrm{P}$ & $\mathrm{P}$ & & $\mathrm{Me}$ & $T$ & \\
\hline SB-07-3 & SB-07 & $P$ & $P$ & $\mathrm{Me}$ & $\mathrm{T}$ & $T$ & \\
\hline SB-08 & SB-08 & $P$ & $P$ & & $\mathrm{Me}$ & $\mathrm{Me}$ & \\
\hline SB-09-1 & SB-09 & $P$ & $\mathrm{Ma}$ & $\mathrm{Ma}$ & $T$ & $\mathrm{Me}$ & $T$ \\
\hline SB-09-2 & SB-09 & $P$ & $\mathrm{Ma}$ & $\mathrm{Ma}$ & $T$ & $\mathrm{Me}$ & $T$ \\
\hline SB-10-1 & SB-10 & $P$ & $\mathrm{Ma}$ & $P$ & $\bar{T}$ & $T$ & $T$ \\
\hline SB-10-2 & SB-10 & $P$ & $\mathrm{Ma}$ & $P$ & $\mathrm{~T}$ & $\bar{T}$ & $T$ \\
\hline SB-11A & SB-11A & $\mathrm{Ma}$ & $\mathrm{Me}$ & $P$ & $\mathrm{~T}$ & $T$ & $T$ \\
\hline SB-11B & SB-11B & $\mathrm{Ma}$ & $\mathrm{P}$ & & & $T$ & \\
\hline SB-11C-1 & SB-11C & $\mathrm{Me}$ & $\mathrm{Ma}$ & & & $P$ & \\
\hline SB-11C-2 & SB-11C & $T$ & $\mathrm{Ma}$ & & & $P$ & \\
\hline SB-11C-3 & SB-11C & & $T$ & & 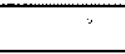 & $P$ & \\
\hline SB-13-1 & SB-13 & $P$ & $\mathrm{Ma}$ & $\mathrm{Me}$ & $T$ & $T$ & $T$ \\
\hline SB-13-2 & SB-13 & $P$ & $\mathrm{Ma}$ & $\mathrm{Me}$ & $T$ & & \\
\hline SB-15A-1 & SB-15A & $P$ & $\mathrm{Ma}$ & $\mathrm{Me}$ & $T$ & $T$ & $\mathrm{~T}$ \\
\hline SB-15A-2 & SB-15A & $P$ & $\mathrm{Ma}$ & $\mathrm{Me}$ & $T$ & $\mathrm{~T}$ & $T$ \\
\hline SB-15A-3 & SB-15A & $P$ & $\mathrm{Ma}$ & $\mathrm{Me}$ & $T$ & $T$ & $\mathrm{~T}$ \\
\hline SB-15C-1 & SB-15C & $P$ & $\mathrm{P}$ & $\mathrm{Me}$ & $T$ & $T$ & $T$ \\
\hline SB-15C-2 & SB-51C & $P$ & $\bar{P}$ & $\mathrm{Me}$ & & $\mathrm{T}$ & $\mathrm{T}$ \\
\hline
\end{tabular}

